\title{
U.S. DEPARTMENT OF ENERGY'S FEDERAL FACILITY COMPLIANCE ACT CHIEF FINANCIAL OFFICER'S REPORT TO CONGRESS FOR FISCAL YEAR 1993
}

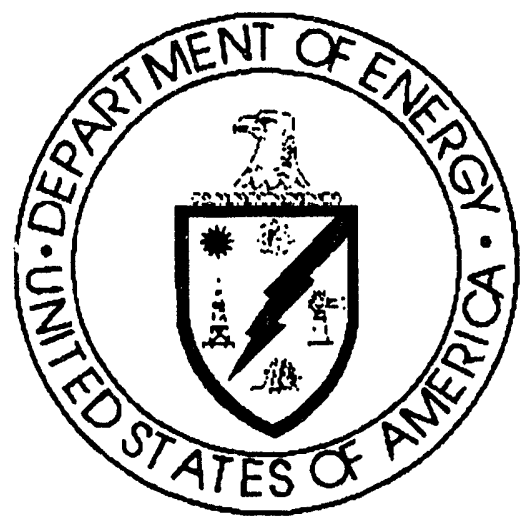

DECEMBER 1993 


\section{U.S. DEPARTMENT OF ENERGY'S FEDERAL FACILITY COMPLIANCE ACT CHIEF FINANCIAL OFFICER'S REPORT TO CONGRESS FOR FISCAL YEAR 1993}

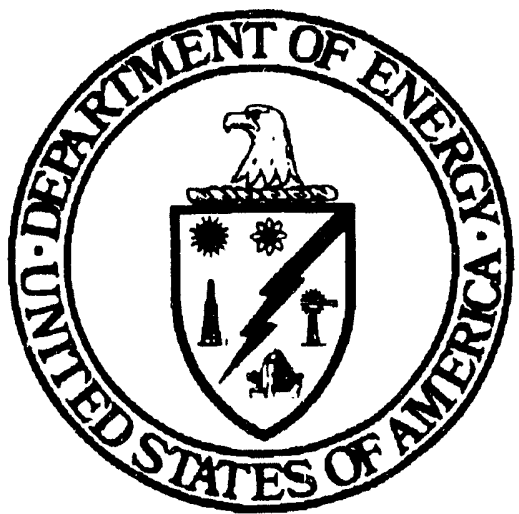

DECEMBER 1993 
I. EXeCUtIVE SUMmary $\ldots \ldots \ldots \ldots \ldots \ldots \ldots \ldots \ldots \ldots \ldots$

II. DEPARTMENT-WIDE RCRA COMPLIANCE ACTIVITIES RELATING TO MIXED WASTE STREAMS $\ldots \ldots \ldots \ldots \ldots \ldots \ldots \ldots \ldots \ldots \ldots \ldots \ldots \ldots \ldots \ldots \ldots$

A. Development of Mixed Waste Inventory Report . . . . . . . . . . . . . 1

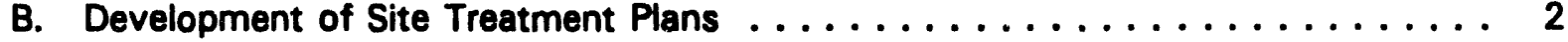

C. National Coordination Effort ....................... 2

D. Discussions And Meetings With the States and the EPA $\ldots \ldots \ldots \ldots \ldots$

III. SITE-SPECIFIC RCRA COMPLIANCE ACTIVITIES RELATED TO MIXED WASTE

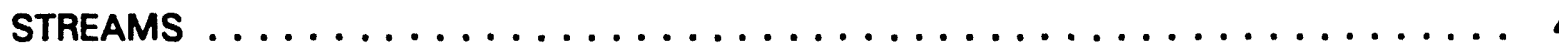

IV. FINES AND PENALTIES IMPOSED UPON THE DOE DURING FY 1993 FOR ALLEGED RCRA VIOLATIONS INVOLVING MIXED WASTE . . . . . . . . . . . . 5

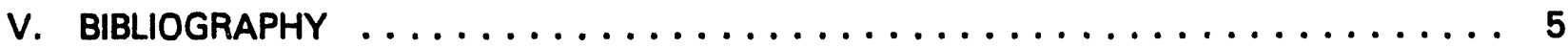

TABLE 1. DIRECTORY OF SITE INFORMATION DETAILS . . . . . . . . . . . 6

TABLE 2. INFORMATION ON THE ALLEGED RCRA VIOLATIONS RELATING TO MIXED WASTE RECEIVED DURING FY 1993 AND ASSOCIATED FINES AND PENALTIES 9

APPENDIX A Site-Specific Fact Sheets $\ldots \ldots \ldots \ldots \ldots \ldots \ldots \ldots \ldots \ldots \ldots$ A-1 


\section{EXECUTIVE SUMMARY}

The Federal Facility Compliance Act of 1992 (FFCAct) (Public Law 102-386) was enacted into law on October 6, 1992. In addition to amending the Resource Conservation and Recovery Act (RCRA), the FFCACt requires the U.S. Department of Energy (DOE) to prepare an annual report from the Chief Financial Officer to the Congress on compliance activities undertaken by the DOE with regard to mixed waste streams and provide an accounting of the fines and penalties imposed upon the DOE for violations involving mixed waste. This document has been prepared to report the necessary information.

Mixed waste is defined by the FFCAct to include those wastes containing both hazardous waste as defined in the RCRA and source, special nuclear, or byproduct material subject to the Atomic Energy Act of 1954, as amended (42 U.S.C. Section 2001 et sea.).

Section II of this report briefly summarizes DOE Headquarters' activities conducted during Fiscal Year 1993 (FY 1993) to comply with the requirements of the FFCAct.

Section III of this report provides an overview of the site-specific RCRA compliance activities, relating to mixed waste streams, conducted in FY 1993 for those sites that currently generate or store mixed waste that are subject to regulation under RCRA.

Section IV provides information on notifications of alleged RCRA violations involving mixed waste imposed upon the DOE during FY 1993 and an accounting of any fines and penalties associated with these violations.

Appendix A provides site-specific summaries of RCRA compliance activities, relating to mixed waste streams, conducted in FY 1993 for those sites that currently generate or store mixed waste that are subject to regulation undt: RCRA.

\section{DEPARTMENT-WIDE RCRA COMPLANCE ACTIVITIES RELATING TO MIXED WASTE STREAMS}

The DOE conducted numerous activities during FY 1993 to comply with the requirements of the FFCAct. These activities include the preparation and submittal of the "Interim Mixed Waste Inventory Report" in April 1993 as required by Section 3021 of the RCRA, as amended; publication of the Federal Register notice in April 1993 that outlines the DOE's basic strategy for preparation of the plans (i.e., Site Treatment Plans) required by Section 3021 (b) of RCRA, as amended; development of a national coordination effort to ensure the Site Treatment Plans are finalized in a manner that allows for long-term RCRA compliance for the DOE mixed waste; and discussions with the states and the EPA to facilitate the Site Treatment Plan development process. The following sections briefly summarize the status of these activities. Additional information on the DOE's progress in complying with the FFCAct may be found in the October 1993 "DOE Federal Facility Compliance Act 12-Month Progress Report to Congress."

\section{A. Development of Mixed Waste Inventory Report}

As required by Section 3021 of the RCRA, as amended by the FFCAct, the DOE prepared and submitted in April, 1993, the "Interim Mixed Waste Inventory Report" to the Administrator of the U.S. Environmental Protection Agency (EPA) and the Governor of each state that hosts a DOE site. This report contained information about the characteristics and treatment requirements for each DOE mixed waste stream, an inventory of existing mixed 
waste treatment capacity, and an inventory of technology capability. The DOE published a notice of its availability to the public on April 23, 1993 (58 Federal Register 25822).

The DOE is currently evaluating comments received from the states, the EPA, and the National Governors' Association and is revising the report as appropriate. The DOE plans to publish the revised report in early 1994. Because waste stream generation is a dynamic process, the DOE intends to update the inventory information on an annual basis.

\section{B. Development of Site Treatment Plans}

Section 3021 (b) of RCRA, as amended by the FFCAct, requires the DOE to develop and submit a plan (i.e., Site Treatment Plan) for developing treatment capacities and technologies for each facility at which DOE generates or stores mixed waste.

On April 6, 1993, the DOE published a notice in the Federal Register (58 FR 17875) outlining its basic strategy for preparation of the Site Treatment Plans. In this notice, the DOE proposed a schedule for developing the Site Treatment Plans in a three-phase process. This process requires that the DOE develop two interim versions of each Site Treatment Plan prior to completing a Final Proposed Site Treatment Plan by February 1995. These interim versions, known as the Conceptual Site Treatment Plan and the Draft Site Treatment Plan, would be submitted to the appropriate state and the EPA for review and comment. The Conceptual and Draft Plans would be due to the appropriate regulatory agencies no later than October 1993 and August 1994, respectively. The DOE is currently implementing this threephase approach. This approach allows the states, the EPA, the DOE, and other interested parties to begin discussion immediately on the Site Treatment Plans and to continue discussion throughout the process.

The DOE identified in the "Interim Mixed Waste Inventory Report" 50 sites that generate or store mixed waste, or plan to generate mixed waste in the next five years. All of these sites, with two exceptions, are preparing Conceptual Site Treatment Plans as a first step in developing a Final Site Treatment Plan. These exceptions are the Hanford Site and the Waste Isolation Pilot Plant (WIPP). The Hanford Site already has in place an agreement among the DOE, the EPA, and the State of Washington to address the site's waste managernent and environmental restoration activities and the requirements pertaining to mixed waste treatment. The State of Washington and the EPA Region $X$ have agreed and provided the DOE with written confirmation that the Hanford Site is not required to submit a Site Treatment Plan. This agreement meets with the conditions set forth in Section 3021 (b)(1)(ii) of RCRA, as amended, for a preexisting agreement involving a state regulatory agency. The WIPP is another site that will not be preparing a Site Treatment Plan because the EPA issued a No Migration Determination to the DOE for WIPP in accordance with Section 3004(u) of RCRA. This variance allows the DOE to emplace a limited quantity of mixed waste in WIPP during a Test Phase lasting up to ten years, without having to meet RCRA Land Disposal Restrictions waste treatment standards. Subsequently, the DOE has determined to conduct the Test Phase in a laboratory environment and not at WIPP. Therefore, no mixed waste will be generated at WIPP during the Test Phase.

\section{National Coordination Effort}

The development of the Site Treatment Plans is a complex task involving all levels of the DOE organization. The DOE Operations and Site Offices have the lead role in developing the plans at each site and working with the regulatory agencies and the local public. The DOE 
Headquarters role in development of the plans is to coordinate among the sites and with the states, the EPA regions, and interested parties to ensure the plans are consistent with the identified needs, capabilities and requirements for the DOE as a whole and to evaluate impact of the plans. To accomplish this task the DOE has undertaken several activities to ensure that activities to develop the Site Treatment Plans are coordinated at a national level. These national coordination activities will help ensure that the Site Treatment Plans are finalized in a manner that will allow for long-term RCRA compliance for the DOE waste. These activities are being conducted in the following areas:

- The DOE-wide strategic planning -- This effort requires the development of the Site Treatment Plans using a "bottom-up" approach and a staged development approach as discussed earlier.

- Technical analysis -- This effort involves the preparation of a crosscut analysis of all Site Treatment Plans allowing the states to compare the alternatives presented in the Site Treatment Plans for their sites and sites in other states.

- Communications and meetings -- This effort involves coordination of information among the DOE sites.

- Policy development and issue resolution -- This effort includes the formation of an internal DOE-wide FFCAct Policy Coordination Group that assists in DOE policy development and analysis.

- Technology development -- This effort requires each Site Treatment Plan to provide a schedule for identifying and developing new technologies, where required, and identifying funding needs. This information will be consolidated and incorporated into a clearinghouse of technical information and will be available to the DOE, the states and the EPA to assist in the Site Treatment Plan development process.

- Programmatic Environmental Impact Statement -- This effort will involve coordinating the development of the DOE's Waste Management Programmatic Environmental Impact Statement (PEIS) being prepared under the National Environmental Policy Act (NEPA) and the Site Treatment Plans to ensure consistency between the documents.

Each of these activities is discussed in greater detail in the October 1993 "DOE Federal Facility Compliance Act 12-Month Progress Report to Congress."

\section{Discussions And Meetings With the States and the EPA}

To facilitate the Site Treatment Plan development process, the DOE contacted and began discussions with host states and Federal regulatory representatives. Almost all DOE-owned sites preparing Site Treatment Plans have initiated contact with their corresponding applicable state or Federal regulators. The DOE is also providing funds through a Cooperative Agreement to the National Governors' Association to support certain FFCAct-related activities. This funding is intended to help facilitate DOE-state interaction, state-to-state discussions, and to keep states informed and involved.

Several states that host more than one DOE site have also initiated meetings and negotiations with the DOE sites they host. Ohio, New York, and California, all of which host three or more DOE facilities, have convened meetings with groups of DOE sites to develop 
a systematic and consistent approach for facilitating development of the Site Treatment Plans and discussing issues of mutual concern. This approach can potentially facilitate the state's Site Treatment Plan review and consultation activities and provide the individual DOE sites with more consistent state guidance. The DOE's October 1993 "Federal Facility Compliance Act 12-month Progress Report to Congress" contains more detailed information on the discussions and meetings between the DOE sites, the states and the EPA.

\section{SITE-SPECIFIC RCRA COMPLIANCE ACTIVITIES RELATED TO MIXED WASTE STREAMS}

This report summarizes in Appendix A the DOE's RCRA compliance activities conducted in FY 1993 for those sites that currently generate or store mixed wastes that are subject to regulation under RCRA. Appendix A provides specific information for each site regarding:

- Existing RCRA Compliance Agreements or Orders and those under negotiation relating to mixed waste;

- Corrective activities conducted during FY 1993 to resolve mixed waste characterization concerns in response to past formal notifications of violations;

- Existing mixed waste storage, treatment and disposal facilities;

- Pertinent ongoing mixed waste activities conducted during FY 1993 to comply with RCRA storage, treatment, and disposal requirements, i.e., special accommodations for radioactive component of waste, internal inspections, facility modifications or upgrades, permit application/modification submittals; and

- Corrective activities conducted during FY 1993 to resolve mixed waste storage, treatment, and disposal concerns in response to past formal notifications of violations.

Although not discussed in the site-specific summaries, most of the sites are storing mixed waste inconsistent with the Land Disposal Restriction provisions because the treatment capacity for such wastes, either at the DOE sites or in the commercial sector, is not adequate or is simply unavailable at this time. Through the Site Treatment Plan development process, the DOE is identifying treatment capacities and needs to help rectify this concern.

The DOE is undertaking cleanup activities pursuant to the corrective action provisions of RCRA. Such cleanup activities, which often address contamination resulting from past disposal practices, are not compliance-related, although the DOE could be subject to enforcement action or fines for failure to meet milestones and schedules established by corrective action plans. Cleanup agreements and other corrective action activities are not discussed in this report. However, any future enforcement action or a compliance activity related to an alleged violation of a corrective action plan would be included in subsequent Chief Financial Officer's reports. Information on corrective action activities are described in the DOE's Annual Report to Congress required by Section 120 (e)(5) of the Comprehensive Environmental Response, Compensation, and Liability Act, which provides a status of DOE's cleanup activities.

A list of the sites included in Appendix A is presented in Table 1. Note that this report does not include all the sites that the DOE identified in its April 1993 "Interim Mixed Waste Inventory Report" because several of the sites listed in that report either (1) did not generate or store mixed waste during FY 1993 or (2) the mixed waste generated or stored at the site are not subject to RCRA regulation, e.g., the state in which the site is located is not authorized to regulate mixed 
waste. Table 1 identifies these sites and provides the basis for not including them in this report. In addition, there are several sites at which the DOE is not responsible for all aspects of waste management at the sites. These sites are included in this report. However, the site-specific fact sheets for these sites provide a discussion on the DOE's responsibilities for the management of the mixed waste at these sites. Additional information on the mixed waste streams and mixed waste treatment capacities and capabilities may be found in the DOE "Interim Mixed Waste Inventory Report."

\section{FINES AND PENALTIES IMPOSED UPON THE DOE DURING FY 1993 FOR ALLEGED RCRA VIOLATIONS INVOLVING MIXED WASTE}

The RCRA Section 3007 authorizes the EPA or states with authorized hazardous waste programs to inspect Federal facilities to verify that Federal facilities comply with RCRA's regulatory requirements. These inspections may include formal site visits, records review, sample collection, and/or observations of operations. After an inspection is completed, the EPA and/or the authorized state typically summarizes the Federal facility's compliance status with respect to RCRA in a letter or report and determines necessary corrective actions, if any. Section 3008 of RCRA authorizes the EPA to take enforcement actions at Federal facilities. Additionally, Section 6001 of RCRA, as amended by the FFCAct, authorizes state regulatory agencies to initiate enforcement actions. Possible enforcement actions may include: administrative actions, civil actions, and criminal actions. Administrative actions may be in several forms ranging from a formal notification to issuance of an administrative order specifying the necessary corrective actions to be taken. Formal notifications include Notices of Violation, Notices of Non-Compliance, Warning Letters and Compliance Letters.

The DOE has received a total of 24 notifications of alleged RCRA violations relating to mixed waste during FY 1993. Only four of these alleged violations have a fine or penalty associated with them. However, failure to respond to the other notifications within the time allotted can result in a fine or penalty. Table 2 provides information on these alleged RCRA violations including the date of receipt, the type of notice, who received the violation, who imposed the violation, description of the alleged violation, any associated fines and penalties assessed, and any responses taken or status of the alleged violation.

\section{BIBLIOGRAPHY}

U.S. Department of Energy, "Interim Mixed Waste Inventory Report," DOE/NBM-1100, April 1993.

U.S. Department of Energy, "DOE Federal Facility Compliance Act 12-Month Progress Report to Congress," DOE/EM-1217, October 1993. 
TABLE 1. DIRECTORY OF SITE INFORMATION DETAILS

\begin{tabular}{|c|c|c|c|}
\hline $\begin{array}{l}\text { STATE/FACILITY AS LISTED IN THE MIXED } \\
\text { WASTE INVENTORY REPORT }\end{array}$ & $\begin{array}{l}\text { SITE REPORT } \\
\text { PAGE NUMBER }\end{array}$ & $\begin{array}{l}\text { SITE DOES } \\
\text { NOT } \\
\text { CURRENTLY } \\
\text { GENERATE } \\
\text { OR STORE } \\
\text { MIXED WASTE } \\
\end{array}$ & $\begin{array}{l}\text { SITE MIXED } \\
\text { WASTE NOT } \\
\text { CURRENTLY } \\
\text { REGULATED } \\
\text { BY RCRA }\end{array}$ \\
\hline \multicolumn{4}{|l|}{ CALIFORNIA: } \\
\hline $\begin{array}{l}\text { Energy Technology Engineering Center } \\
\text { General Atomics } \\
\text { General Electric Vallectos } \\
\text { Laboratory For Energy-Related Health Research } \\
\text { Lawrence Berkeley Laboratory } \\
\text { Lawrence Livermore National Laboratory } \\
\text { Mare Island Naval Shipyard } \\
\text { Sandia National Laboratory - California }\end{array}$ & $\begin{array}{c}\text { A-3 } \\
\text { A-5 } \\
\text { Not Included } \\
\text { A-7 } \\
\text { A-9 } \\
\text { A-11 } \\
\text { A-13 } \\
\text { A-14 }\end{array}$ & $x$ & \\
\hline \multicolumn{4}{|l|}{ COLORADO: } \\
\hline $\begin{array}{l}\text { Grand Junction Projects Office } \\
\text { Rocky Flats Plant }\end{array}$ & $\begin{array}{l}A-17 \\
A-18 \\
\end{array}$ & & \\
\hline \multicolumn{4}{|l|}{ CONNECTICUT: } \\
\hline Knolls Atomic Power Laboratory & Not Included & $\mathrm{x}$ & \\
\hline \multicolumn{4}{|l|}{ FLORIDA: } \\
\hline Pinellas Plant & $A-25$ & & \\
\hline \multicolumn{4}{|l|}{ HAWAll: } \\
\hline Pearl Harbor Naval Shipyard & A-29 & & \\
\hline \multicolumn{4}{|l|}{ IDAHO: } \\
\hline $\begin{array}{l}\text { Argonne National Laboratory - West } \\
\text { Idaho National Engineering Laboratory }\end{array}$ & $\begin{array}{l}\text { A-33 } \\
\text { A-35 } \\
\end{array}$ & & \\
\hline \multicolumn{4}{|l|}{ ILLINOIS: } \\
\hline $\begin{array}{l}\text { Argonne National Laboratory - East } \\
\text { Site A/Plot M, Palo Forest Preserve }\end{array}$ & $\begin{array}{c}\text { A-41 } \\
\text { Not Included } \\
\end{array}$ & $x$ & \\
\hline \multicolumn{4}{|l|}{ IOWA: } \\
\hline Ames Laboratory & A-45 & & \\
\hline
\end{tabular}


TABLE 1. DIRECTORY OF SITE INFORMATION DETAILS (Continued)

\begin{tabular}{|c|c|c|c|}
\hline $\begin{array}{l}\text { STATE/FACILITY AS LISTED IN THE MIXED } \\
\text { WASTE INVENTORY REPORT }\end{array}$ & $\begin{array}{l}\text { SITE REPORT } \\
\text { PAGE NUMBER }\end{array}$ & $\begin{array}{l}\text { SITE DOES } \\
\text { NOT } \\
\text { CURRENTLY } \\
\text { GENERATE } \\
\text { OR STORE } \\
\text { MIXED WASTE }\end{array}$ & $\begin{array}{l}\text { SITE MIXED } \\
\text { WASTE NOT } \\
\text { CURRENTLY } \\
\text { REGULATED } \\
\text { BY RCRA }\end{array}$ \\
\hline \multicolumn{4}{|l|}{ KENTUCKY: } \\
\hline Paducar Gaseous Diffusion Plant & A-49 & & \\
\hline \multicolumn{4}{|l|}{ MAINE: } \\
\hline Portsmouth Naval Shipyard & Not Included & & $x$ \\
\hline \multicolumn{4}{|l|}{ MISSOURI: } \\
\hline $\begin{array}{l}\text { Kansas City Plant } \\
\text { University of Missouri } \\
\text { Weldon Spring Site Remedial Action Project }\end{array}$ & $\begin{array}{l}\text { A-53 } \\
\text { A-54 } \\
\text { A-55 } \\
\end{array}$ & & \\
\hline \multicolumn{4}{|l|}{ NEVADA: } \\
\hline Nevada Test Site & A-59 & & \\
\hline \multicolumn{4}{|l|}{ NEW JERSEY: } \\
\hline $\begin{array}{l}\text { Middlesex Sampling Plant } \\
\text { Princeton Plasma Physics Laboratory }\end{array}$ & $\begin{array}{l}\text { Not Included } \\
\text { Not Included }\end{array}$ & $\mathrm{x}$ & $\begin{array}{l}x \\
x \\
\end{array}$ \\
\hline \multicolumn{4}{|l|}{ NEW MEXICO: } \\
\hline $\begin{array}{l}\text { Inhalation Toxicology Research Institute } \\
\text { Los Alamos National Laboratory } \\
\text { Sandia National Laboratory - New Mexico } \\
\text { Waste Isolation Pilot Plant }\end{array}$ & $\begin{array}{c}\text { A-63 } \\
\text { A-64 } \\
\text { A-66 } \\
\text { Not Included }\end{array}$ & $x$ & \\
\hline \multicolumn{4}{|l|}{ NEW YORK: } \\
\hline $\begin{array}{l}\text { Brookhaven National Laboratory } \\
\text { Colonie Interim Storage Site } \\
\text { Knolls Atomic Power Laboratory, Kesselring } \\
\text { Knolls Atomic Power Laboratory, Schenectady } \\
\text { West Valley Demonstration Project }\end{array}$ & $\begin{array}{l}A-71 \\
A-73 \\
A-75 \\
A-76 \\
A-78\end{array}$ & & \\
\hline
\end{tabular}


TABLE 1. DIRECTORY OF SITE INFORMATION DETAILS (Continued)

\begin{tabular}{|c|c|c|c|}
\hline $\begin{array}{l}\text { STATE/FACILITY AS LISTED IN THE MIXED } \\
\text { WASTE INVENTORY REPORT }\end{array}$ & $\begin{array}{l}\text { SITE REPORT } \\
\text { PAGE NUMBER }\end{array}$ & $\begin{array}{c}\text { SITE DOES } \\
\text { NOT } \\
\text { CURRENTLY } \\
\text { GENERATE } \\
\text { OR STORE } \\
\text { MIXED WASTE }\end{array}$ & $\begin{array}{l}\text { SITE MIXED } \\
\text { WASTE NOT } \\
\text { CURRENTLY } \\
\text { REGULATED } \\
\text { BY RCRA }\end{array}$ \\
\hline \multicolumn{4}{|l|}{ OHIO: } \\
\hline $\begin{array}{l}\text { Battelle Columbus Laboratories } \\
\text { Decommissioning Project }\end{array}$ & A-83 & & \\
\hline Fernald Environmental Management Project & A-84 & & \\
\hline Mound Plant & A-87 & & \\
\hline Portsmouth Gaseous Diffusion Plant & A-88 & & \\
\hline RMI Titanium, Inc. & A-90 & & \\
\hline \multicolumn{4}{|l|}{ PENNSYLVANIA: } \\
\hline Bettis Atomic Power Laboratory & Not Included & & $x$ \\
\hline \multicolumn{4}{|l|}{ SOUTH CAROLINA: } \\
\hline Charleston Naval Shipyard & A-95 & & \\
\hline Savannah River Site & A-96 & & \\
\hline \multicolumn{4}{|l|}{ TENNESSEE: } \\
\hline K-25, Oak Ridge Reservation & A-103 & & \\
\hline $\begin{array}{l}\text { Oak Ridge National Laboratory, Oak Ridge } \\
\text { Reservation }\end{array}$ & A-105 & & \\
\hline Y-12 Plant, Oak Ridge Reservation & A-107 & & \\
\hline \multicolumn{4}{|l|}{ TEXAS: } \\
\hline Pantex Plant & A-111 & & \\
\hline \multicolumn{4}{|l|}{ VIRGINIA: } \\
\hline Norfolk Naval Shipyard & Not Included & $x$ & $x$ \\
\hline \multicolumn{4}{|l|}{ WASHINGTON: } \\
\hline Hanford Site & $A-115$ & & \\
\hline Puget Sound Naval Shipyard & A-117 & & \\
\hline
\end{tabular}


TABLE 2. INFORMATION ON THE ALLEED RCRA VIOLATIONS RELATING TO MIXED WASTE RECEIVED DURING FY 1993 AND ASSOCIATED FINES AND PENALTIES

\begin{tabular}{|c|c|c|c|c|c|c|}
\hline Dute Rocoived & 'Type of Notice' & $\begin{array}{l}\text { Violation sent to } \\
\text { (DOE/Contractor) }\end{array}$ & $\begin{array}{l}\text { Rocolvod From } \\
\text { (Stato/EPA) }\end{array}$ & Description of Alloged Volotion & $\begin{array}{l}\text { Fino/Ponalty } \\
\text { (Aseceoced of } \\
\text { Pald) }\end{array}$ & $\begin{array}{l}\text { Rosponee Taken/ } \\
\text { Statue Update }\end{array}$ \\
\hline Fobruary 2, 1993 & Notice of Violation & DOE & State of ldaho & $\begin{array}{l}\text { Storege of mixed waste semples in } \\
\text { laboratorios. }\end{array}$ & None & $\begin{array}{l}\text { Undergoing } \\
\text { negotiations. }\end{array}$ \\
\hline \multicolumn{7}{|c|}{ WELOON SPRIN C REMUEDIAL ACTION PROJECT IMISSOUAII) } \\
\hline August 31, 1993 & Worning Lotter & DOE & $\begin{array}{l}\text { Missouri } \\
\text { Department of } \\
\text { Neturel } \\
\text { Resources }\end{array}$ & $\begin{array}{l}\text { Storago-Related; Recordkeoping- } \\
\text { related. }\end{array}$ & None $^{2}$ & $\begin{array}{l}\text { Reoponse with } \\
\text { Corroctive Action } \\
\text { Plan submittod } \\
\text { Soptembor 21. } \\
1993 . \\
\end{array}$ \\
\hline \multicolumn{7}{|c|}{ LOS ALAMOS NATIONAL LABORATORY INEW MEXICO) } \\
\hline $\begin{array}{l}\text { January } 28 . \\
1993\end{array}$ & Notice of Violations & $\begin{array}{l}\text { DOE and } \\
\text { Contractor }\end{array}$ & $\begin{array}{l}\text { Now Moxico } \\
\text { Environmont } \\
\text { Department }\end{array}$ & $\begin{array}{l}\text { Non-compliant storege of weste at } \\
\text { Tochnical Area } 54 \text {. Ares G. Failure } \\
\text { to maintain drum integrity at } \\
\text { Technicel Aroe 54. Aros G. }\end{array}$ & $\begin{array}{l}\$ 1,283,5,50 \\
\text { (Assessed) }\end{array}$ & $\begin{array}{l}\text { DOE and } \\
\text { contractor heve } \\
\text { comploted } \\
\text { nogotiations. The } \\
\text { penelty was } \\
\text { negotiated } \\
\text { downward to } \\
\$ 700,000 \text {. } \\
\text { Signature by all } \\
\text { parties is } \\
\text { pending. }\end{array}$ \\
\hline $\begin{array}{l}\text { Jemuery } 28 . \\
1993\end{array}$ & Notice of Violations & $\begin{array}{l}\text { DOE and } \\
\text { Contractor }\end{array}$ & $\begin{array}{l}\text { Now Moxico } \\
\text { Environment } \\
\text { Department }\end{array}$ & $\begin{array}{l}\text { Various operationel violations meinly } \\
\text { at genurator location. }\end{array}$ & $\begin{array}{l}\$ 352,605 \\
\text { (Assessed) }\end{array}$ & $\begin{array}{l}\text { DOE and } \\
\text { contractor have } \\
\text { initiated } \\
\text { settlement } \\
\text { discussions to } \\
\text { resolve emount of } \\
\text { penaltios and to } \\
\text { develop a } \\
\text { Compliance } \\
\text { Ordor. }\end{array}$ \\
\hline
\end{tabular}




\begin{tabular}{|c|c|c|c|c|c|c|}
\hline Dane Rocotrod & 'Trpe of Notice' & $\begin{array}{l}\text { Violation sent to } \\
\text { (DOE/Contractor) }\end{array}$ & $\begin{array}{l}\text { Rocolvod From } \\
\text { (Stote/EPA) }\end{array}$ & Desceription of Alloged Vholation & $\begin{array}{l}\text { Frrouponaty } \\
\text { (Meacesood or } \\
\text { Pold) }\end{array}$ & $\begin{array}{l}\text { Reaponeo Takon/ } \\
\text { Stotue Updote }\end{array}$ \\
\hline \multicolumn{7}{|c|}{ SANDIA NATIONAL LABORATORY (NEW MEXICO) } \\
\hline $\begin{array}{l}\text { Septomber 8, } \\
1993\end{array}$ & Compliance Order & $\begin{array}{l}\text { DOE and } \\
\text { Contractor }\end{array}$ & $\begin{array}{l}\text { Now Mexico } \\
\text { Environment } \\
\text { Department }\end{array}$ & Storago-related. & $\begin{array}{l}\text { :3,892 } \\
\text { (Peid) }\end{array}$ & $\begin{array}{l}\text { Violation } \\
\text { corrocted. } \\
\text { Additionel fines } \\
\text { peid for other } \\
\text { non-mixed waste. }\end{array}$ \\
\hline \multicolumn{7}{|c|}{ COLONIE WTERIM BTORAGE SITE (NEW YORK). } \\
\hline April 30, 1993 & Notice of Violation & $\begin{array}{l}\text { DOE and } \\
\text { Contractor }\end{array}$ & $\begin{array}{l}\text { Now York } \\
\text { State } \\
\text { Dopertment of } \\
\text { Environmontel } \\
\text { Conservation }\end{array}$ & $\begin{array}{l}\text { Questions resulting from a RCRA } \\
\text { oudit conductod in August 1992, } \\
\text { that primarily covered treining } \\
\text { rocords, drum movement, omergeney } \\
\text { contects, and wasto handlore. }\end{array}$ & None & $\begin{array}{l}\text { Resolution } \\
\text { peckage } \\
\text { submitted on Moy } \\
28,1993 \text { and } \\
\text { violation closed } \\
\text { on June 14, } \\
1993 \text {. } \\
\end{array}$ \\
\hline \multicolumn{7}{|c|}{ FERMALO ENVIRONMENTAL MANACEENENT PROUECT IOHOO } \\
\hline July 19, 1993 & Notice of Violetion & DOE & Ohio EPA & $\begin{array}{l}\text { Storege of waste restricted from land } \\
\text { disposal for longer than ellowod. }\end{array}$ & None & $\begin{array}{l}\text { Conducting } \\
\text { nctions required } \\
\text { by FFCAct. }\end{array}$ \\
\hline \multicolumn{7}{|c|}{ PORTSMOUTH CASEOUS DIFFUSION PLANT (OHO) } \\
\hline $\begin{array}{l}\text { Jamuery 22, } \\
1993\end{array}$ & Notice of Volation & DOE & Ohio EPA & $\begin{array}{l}\text { Failure to lobel conteiner with } \\
\text { hazardous waste. Foilure to comply } \\
\text { with setellite accumulation rule. }\end{array}$ & None & $\begin{array}{l}\text { The drum was } \\
\text { properly lebelod } \\
\text { ond the eatellite } \\
\text { area was }\end{array}$ \\
\hline $\begin{array}{l}\text { Jamuary } 22 . \\
1993\end{array}$ & Notice of Violetion & DOE & Ohio EPA & $\begin{array}{l}\text { DOE foilor' to conduct wookly tosts } \\
\text { and mointein tosting loge for fire } \\
\text { oxtinguishors locatod in 90-day } \\
\text { storege areas of the plent. }\end{array}$ & None & $\begin{array}{l}\text { The checklist was } \\
\text { revised to } \\
\text { indicato the fire } \\
\text { extinguisher } \\
\text { check was boing } \\
\text { mede. }\end{array}$ \\
\hline
\end{tabular}




\begin{tabular}{|c|c|c|c|c|c|c|}
\hline Dato Rocolvod & 'Type of Notice' & $\begin{array}{l}\text { Violation Sont to } \\
\text { (DOE/Contractor) }\end{array}$ & $\begin{array}{l}\text { Rocolved From } \\
\text { (State/EPA) }\end{array}$ & Deseription of Alloged Viletetion & $\begin{array}{l}\text { Fino/Ponalty } \\
\text { (Mosecesed or } \\
\text { Pald) }\end{array}$ & $\begin{array}{l}\text { Reoponee Taken/ } \\
\text { Stetue Update }\end{array}$ \\
\hline \multicolumn{7}{|c|}{ PORTSMOUTH GASEOUS DIFFUSION PLANT ICOntinted I } \\
\hline $\begin{array}{l}\text { Jenuary 22, } \\
1993 \\
\text { Jemuery } 22 . \\
1993\end{array}$ & $\begin{array}{l}\text { Notice of Violation } \\
\text { Notice of Violation }\end{array}$ & DOE & $\begin{array}{l}\text { Ohio EPA } \\
\text { Ohio EPA }\end{array}$ & $\begin{array}{l}\text { DOE stored hazardous waste in } \\
\text { conteiners that woro not in good } \\
\text { condition. } \\
\text { DoE falled to lebel a drum with the } \\
\text { words "Hazardous Woste." }\end{array}$ & $\begin{array}{l}\text { None } \\
\text { None }\end{array}$ & $\begin{array}{l}\text { The conteinore } \\
\text { wore repackeged. } \\
\text { DOE immodietely } \\
\text { lebeled the drum. }\end{array}$ \\
\hline \multicolumn{7}{|c|}{ HANFOAD STIE (WASFWCTONI } \\
\hline $\begin{array}{l}\text { October } 27 . \\
1992\end{array}$ & Complience Letter & $\begin{array}{l}\text { DOE and } \\
\text { Contrector }\end{array}$ & $\begin{array}{l}\text { Weshington } \\
\text { Stete } \\
\text { Dopartment of } \\
\text { Ecology }\end{array}$ & $\begin{array}{l}\text { Feilure to moet the wasts generetor } \\
\text { and eccumulation standerds, such oe } \\
\text { westo designation, porsonnel } \\
\text { treining, recordkooping, and the use } \\
\text { and manegerment of conteiners. }\end{array}$ & Nono'2 & $\begin{array}{l}\text { lesued a response } \\
\text { within the } \\
\text { designated time } \\
\text { period. Finel } \\
\text { resolution is } \\
\text { pending. }\end{array}$ \\
\hline $\begin{array}{l}\text { Octobor } 30 . \\
1992\end{array}$ & Complience Lottor & $\begin{array}{l}\text { DOE and } \\
\text { Contractor }\end{array}$ & $\begin{array}{l}\text { Weahington } \\
\text { State } \\
\text { Dopartment of } \\
\text { Ecology }\end{array}$ & $\begin{array}{l}\text { In violetion of Stete Dengoroue } \\
\text { Weste Regulations duo to improper } \\
\text { waste dosignation, inedequete } \\
\text { contingeney plan, inedequate waste } \\
\text { inventory, improper conteiner } \\
\text { lebeling, and improper storege of } \\
\text { waste according to the fire code. }\end{array}$ & None $^{2}$ & $\begin{array}{l}\text { lesued a reaponse } \\
\text { that disputes ell } \\
\text { findings. Finel } \\
\text { resolution is } \\
\text { pending. }\end{array}$ \\
\hline March 10, 1993 & $\begin{array}{l}\text { Enforcement Order and } \\
\text { Notice of Penalty } \\
\text { Incurred and Dus }\end{array}$ & $\begin{array}{l}\text { DOE and } \\
\text { Contrector }\end{array}$ & $\begin{array}{l}\text { Weshington } \\
\text { Stote } \\
\text { Department of } \\
\text { Ecology }\end{array}$ & $\begin{array}{l}\text { Feilure to edequately dosignate } \\
\text { epproximatoly } 2,000 \text { conteinere of } \\
\text { solid wasto. }\end{array}$ & $\begin{array}{l}100,000 \\
\text { (Assessod) }\end{array}$ & $\begin{array}{l}\text { Disputed the } \\
\text { order and penelty. } \\
\text { The State } \\
\text { Pollution Control } \\
\text { Hearing Boond has } \\
\text { uphold both the } \\
\text { order and the } \\
\text { penelty but has } \\
\text { modifiod the } \\
\text { order vis a } \\
\text { sottlement } \\
\text { egroement. Finel } \\
\text { resolution is } \\
\text { pending. }\end{array}$ \\
\hline
\end{tabular}




\begin{tabular}{|c|c|c|c|c|c|c|}
\hline Date Rocolved & 'Type of Notice' & $\begin{array}{l}\text { Vidation Sont to } \\
\text { (DOE/Contractor) }\end{array}$ & $\begin{array}{l}\text { Rocoived From } \\
\text { (State/EPA) }\end{array}$ & Description of Alloged Vloletion & $\begin{array}{l}\text { Fine/Ponelty } \\
\text { (Aececeed or } \\
\text { Pold) }\end{array}$ & $\begin{array}{l}\text { Rerponee Tokon/ } \\
\text { Statue Updote }\end{array}$ \\
\hline \multicolumn{7}{|c|}{ HANFORD SITE (Continund) } \\
\hline May 12, 1993 & Compliance Letter & $\begin{array}{l}\text { DOE and } \\
\text { Contractor }\end{array}$ & $\begin{array}{l}\text { Weshington } \\
\text { State } \\
\text { Department of } \\
\text { Ecology }\end{array}$ & $\begin{array}{l}\text { Inadequate reporting of and access to } \\
\text { information regarding a spill of } \\
\text { ethylene glycol. }\end{array}$ & None'2 & $\begin{array}{l}\text { Prepered a } \\
\text { response within } \\
\text { the required time } \\
\text { period. Find } \\
\text { resolution is } \\
\text { pending. }\end{array}$ \\
\hline Mov 24, 1993 & Complience Lottor & $\begin{array}{l}\text { DOE and } \\
\text { Controctor }\end{array}$ & $\begin{array}{l}\text { Weshington } \\
\text { State } \\
\text { Dopartment of } \\
\text { Ecology }\end{array}$ & $\begin{array}{l}\text { Violations of various reguletions } \\
\text { related to tank systom compliance. }\end{array}$ & None' & $\begin{array}{l}\text { Prepered a } \\
\text { response and } \\
\text { committed to } \\
\text { pumping } \\
\text { remsining liquids } \\
\text { from tenk. Find } \\
\text { resolution is } \\
\text { ponding. }\end{array}$ \\
\hline July 9, 1993 & Compliance Letter & $\begin{array}{l}\text { DOE and } \\
\text { Controctor }\end{array}$ & $\begin{array}{l}\text { Weshington } \\
\text { Stete } \\
\text { Dopertment of } \\
\text { Ecology }\end{array}$ & $\begin{array}{l}\text { Violetions of the gonerator } \\
\text { accumulation standards of } \\
\text { Washington Administrative Code } \\
\text { 173-303-200. }\end{array}$ & Nono $^{2}$ & $\begin{array}{l}\text { Propared a formel } \\
\text { response. Find } \\
\text { resolution is } \\
\text { pending. }\end{array}$ \\
\hline August 24, 1993 & Compliance Letter & $\begin{array}{l}\text { DOE and } \\
\text { Contractor }\end{array}$ & $\begin{array}{l}\text { Weshington } \\
\text { State } \\
\text { Dopertmont of } \\
\text { Ecology }\end{array}$ & $\begin{array}{l}\text { Violetion of 90-day accumulation } \\
\text { limits. }\end{array}$ & None $^{2}$ & $\begin{array}{l}\text { Although the } \\
\text { contractor and } \\
\text { DOE-Richland } \\
\text { submittod a } \\
\text { request for a } 30 \text { - } \\
\text { dey oxtension, } \\
\text { the roquest was } \\
\text { conditionally } \\
\text { donied until the } \\
\text { contractor and } \\
\text { DOE-Richlend } \\
\text { provided the } \\
\text { Stete with a date } \\
\text { on which the } \\
\text { westo transfor }\end{array}$ \\
\hline
\end{tabular}


TABLE 2. INFORMATION ON THE ALLEGED RCRA VIOLATIONS RELATING TO MIXED WASTE RECEIVED DURING FY 1993 AND ASSOCIATED FINES AND PENALTIES (Continued)

\begin{tabular}{|c|c|c|c|c|c|c|}
\hline Date Recoived & 'Type of Notice' & $\begin{array}{l}\text { Violation Sont to } \\
\text { (DOE/Contractor) }\end{array}$ & $\begin{array}{l}\text { Rocolved From } \\
\text { (State/EPA) }\end{array}$ & Description of Alleged Violation & $\begin{array}{l}\text { FinerPonelty } \\
\text { (Alececeed or } \\
\text { Poid) }\end{array}$ & $\begin{array}{l}\text { Roeponee Takon/ } \\
\text { statue Update }\end{array}$ \\
\hline \multicolumn{7}{|c|}{ HANFORD SITE (Continued) } \\
\hline $\begin{array}{l}\text { August 24, } 1993 \\
\text { (Continued) }\end{array}$ & & & & & & $\begin{array}{l}\text { would be } \\
\text { comploto. This } \\
\text { information wos } \\
\text { providod on } \\
\text { August 26, } 1993 . \\
\text { No odditional } \\
\text { octions are } \\
\text { nocessery. }\end{array}$ \\
\hline
\end{tabular}

' Compliance Order; Notice of Violation; Compliance Letter; Warning Letter; Violation of Administrative Order or Consent Order.

2 These items are not violetions for which the regulator assesses fines or penelties. If the DOE does not respond to the Compliance Letter, or Werning Letter within the time allotted, a Notice of Violation may be issued. 


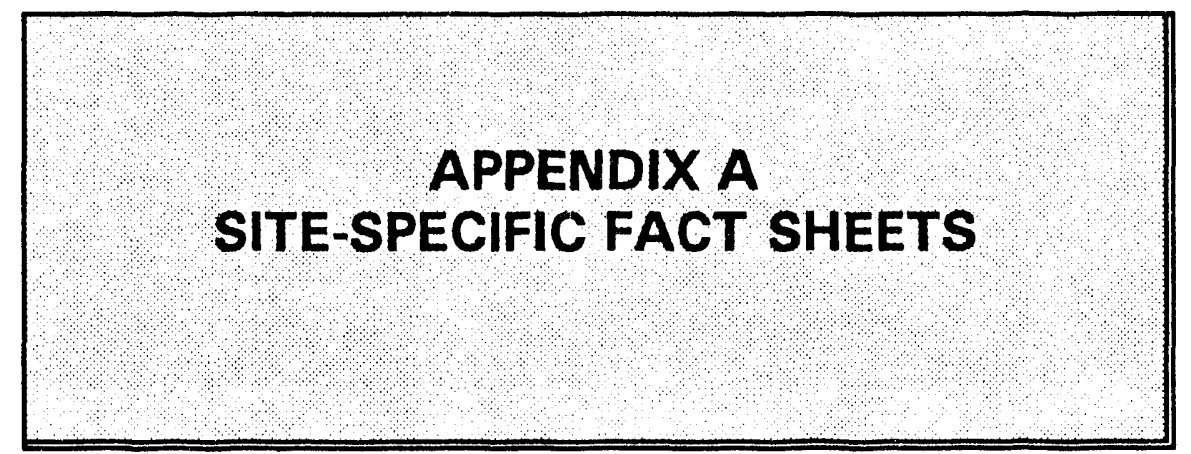




\section{CALIFORNIA}


This page intentionally left blank.

CHIEF FINANCIAL OFFICER'S REPORT-1993

A-2 


\section{ENERGY TECHNOLOGY ENGINEERING CENTER Canoga Park, California}

Mission: The Energy Technology Engineering Center (ETEC) develops energy technologies, and engineers, tests, and develops components related to liquid-metals technology in support of the U.S. Department of Energy.

\section{RCRA COMPLIANCE AGREEMENTS OR ORDERS RELATING TO MIXED WASTE}

The ETEC currently does not have any RCRA Compliance Agreements or Orders that relate to mixed waste.

\section{MIXED WASTE CHARACTERIZATION ACTIVITIES FOR FY 1993}

There were no activities conducted during FY 1993 to correct any past formal notifications of RCRA violations of waste characterization activities.

\section{MIXED WASTE STORAGE ACTIVITIES FOR FY 1993}

The ETEC has one waste storage facility that stores both mixed low-level and mixed transuranic waste. This facility has the capacity to store $240 \mathrm{~m}^{3}$ of waste and is currently operated under interim status. Transuranic mixed waste is stored in a secure shielded area within the storage facility.

Internal Inspections -- The mixed waste storage facility is inspected weekly by facility personnel. Audits and surveillance of the facility are conducted by the Quality Assurance and Environmental Protection Department. Any noncompliances identified during these inspections are reported through the Environmental Protection Department to the State of California or the EPA. No significant compliance problems were identified during FY 1993 at the mixed waste storage facility.

External Inspections -- No inspections were conducted by the EPA or the State of California during FY 1993.

Facility Upgrades or Modifications -- No upgrades or modifications to the mixed waste storage facility were conducted during FY 1993.

Permit Modifications or Applications -- No RCRA permit modifications or applications relating to mixed waste were submitted during FY 1993.

\section{MIXED WASTE TREATMENT ACTIVITIES FOR FY 1993}

The ETEC has one waste treatment facility that treats mixed low-level waste. This facility is currently operated under interim status.

Internal Inspections -- The mixed waste treatment facility is inspected weekly by facility personnel. Audits and surveillance of the facility is conducted by the Quality Assurance and Environmental Protection Department. Any nioncompliances identified during these inspections are reported through 
the Environmental Protection Department to the State of California or the EPA. No significant compliance problems were identified during FY 1993 at the mixed waste treatment facility.

External Inspections -- No inspections were conducted by the EPA or the State of California during FY 1993.

Facility Upgrades or Modifications -- No upgrades or modifications to the mixed waste treatment facility were conducted during FY 1993.

Permit Modifications or Applications -- No RCRA permit modifications or applications relating to mixed waste were submitted during FY 1993.

\section{MIXED WASTE DISPOSAL ACTIVITIES FOR FY 1993}

The ETEC does not have any mixed waste disposal facilities. 


\section{GENERAL ATOMICS \\ San Diego, California}

Mission: General Atomics, a privately owned and operated nuclear facility, has supported government nuclear energy programs, primarily for the Atomic Energy Commission and DOE, since the late 1950 s. General Atomics is currently oenerating and storing mixed waste resulting from General Atomics' Fuel Fabrication Facility decontamination and dismantlement project. Hot Cell Facility decontamination and decommissioning (D\&D) will also oenerate a small amount of mixed waste when D\&D begins in late 1994.

\section{RCRA COMPLIANCE AGREEMENTS OR ORDERS RELATING TO MIXED WASTE}

General Atomics currently does not have any RCRA Compliance Agreements or Orders that relate to mixed waste.

\section{MIXED WASTE CHARACTERIZATION ACTIVITIES FOR FY 1993}

During an internal inspection conducted in April 1993, it was noted that some containerized mixed waste stored in the facility had not been fully characterized with regard to RCRA and the California Hazardous Waste Control Laws. This was reported to the State of California EPA on April 30, 1993. To currect this violation, field screening and laboratory analysis of ten percent of the containers for each identified waste stream was conducted and new procedures to assure that all wastes are adequately characterized in the future have been developed and implemented.

\section{MIXED WASTE STORAGE ACTIVITIES FOR FY 1993}

General Atomics has interim status for mixed waste managed at three separate areas on the site. Each of these separate management facility areas has a mixed waste container storage area used for the storage of mixed low-level waste.

Internal Inspections -- The mixed waste container storage areas are inspected weekly by facility personnel and quarterly by the Emergency Services Supervisor. Anv noncompliance identified during an internal inspection is reported to the manager of the facility, the Emergency Services Supervisor, the Hazardoús Materials Manager, and the Director of Licensing, Safety, and Nuclear Compliance. The need to report to external agencies is determined by the Emergency Services Supervisor and the ridzardous Materials Manager.

During an internal inspection conducted in April 1993, it was noted that some containerized mixed wastes were not properly stored, segregated, or marked. In addition, it was noted that some wastes stored in the facility were not included in the existing RCRA Part A Permit Application. As a result of these findings, secondary containment was added to the facility; the stored containers were reorganized; the container markings were corrected based on results of waste analyses; the RCRArequired plans, container storage areas, emergency response equipment, documentation and recordkeeping were upgraded; procedures for container marking, segregation, and storage were revised; personnel were trained on appropriate storage requirements; and an amendment to the existing RCRA Part A Permit Application was submitted. 
External Inspections -- No inspections were conducted by the EPA or the State of California during FY 1993.

Facility Upgrades or Modifications -- A cover was added to container storage area for the ignitable wastes to provide protection from radiant heat. Secondary containment berms and/or containment pallets were added to all container storage areas.

Permit Modifications or Applications -- An amendment to the existing RCRA Part A Permit Application was submitted to the California EPA on July 15, 1993.

\section{MIXED WASTE TREATMENT ACTIVITIES FOR FY 1993}

General Atomics has six mixed waste treatment urits located within the Mixed Waste Management Facility. Five of these units are currently operating under interim status and treat mixed low-level waste; the other unit is under construction and will also treat mixed waste.

Internal Inspections -- The mixed waste treatment units located within the mixed waste management facility are inspected daily by facility operators when the units are operated. The units are inspected weekly by facility personnel and quarterly by the Emergency Services Supervisor. The facility records associated with the mixed waste treatment units within the facility are inspected quarterly by the Facility Manager for completeness, accuracy, and regulatory compliance.

The mixed waste treatment units located elsewhere on site but not within the mixed waste management facility are inspected daily by work area staff operators when the units are operated. The units are inspected weekly by work area staff and quarterly by the work area manager. The facility records associated with the mixed waste treatment units located elsewhere on site are inspected quarterly.

Any noncompliance identified during an internal inspection is reported to the manager of the facility, the Emergency Services supervisor, the Hazardous Materials Manager, and the Director of Licensing, Safetv, and Nuclear Compliance. The need to report to external agencies is determined by the Emergency Services Supervisor and the Hazardous Materials Manager. No significant compliance problems were identified during FY 1993 at the mixed waste treatment units.

External Inspections -- No inspections were conducted by the EPA or the State of California during FY 1993.

Facility Uparades or Modifications -- Enclosure structure and secondary containment berms were added around the Filtration Area which houses two of the mixed waste treatment units.

Permit Modifications or Applications -- The Onsite Hazardous Waste Treatment Notification was submitted to the California EPA on March 31, 1993. An amendment to the existing RCRA Part A Permit Application was submitted to California EPA on July 15, 1993.

\section{MIXED WASTE DISPOSAL ACTIVITIES FOR FY 1993}

General Atomics does not have any mixed waste disposal facilities. 


\section{LABORATORY FOR ENERGY-RELATED HEALTH RESEARCH \\ Davis, California}

Mission: The Laboratory for Energy-Related Health Research (LEHR) conducted research on the potential health effects to dogs when they are exposed to bone-seeking radionuclides. In 1988, DOE decided to close out the research program, shut down the Laboratory for Energy-Related Health Research, and return the facilities and the site to the University of California, Davis, for unrestricted use after remediation. The Laboratory for Energy-Related Health Research is an inactive facility with no future DOE use.

\section{RCRA COMPLIANCE AGREEMENTS OR ORDERS RELATING TO MIXED WASTE}

The LEHR currently does not have any RCRA Compliance Agreements or Orders relating to mixed waste.

\section{MIXED WASTE CHARACTERIZATION ACTIVITIES FOR FY 1993}

On May 11,1993 , during the DOE Headquarters audit of the LEHR Environmental Restoration program, it was identified that the RCRA Part A ?ermit Application did not accurately reflect the mixed waste being stored at the LEHR and the waste was not adequately characterized. The California Department of Toxic Substance Control was notified of this finding. In order to correct the situation, the LEHR is currently revising the RCRA Part A Permit Application for submittal to the California Department of Toxic Substance Control as part of an "interim status" change. In addition, the LEHR is currently preparing a work plan for waste characterization.

\section{MIXED WASTE STORAGE ACTIVITIES FOR FY 1993}

The LEHR has one mixed waste storage facility with a total capacity of 2,100 gallons. This facility is operated under interim status and stores mixed low-level waste.

Internal Inspections -- The mixed waste storage facility is inspected weekly. If a noncompliance item is found it is documented and the on-site LEHR project manager is notified. Corrective action is initiated when a problem is identified. Monthly walk-throughs of these facilities are conducted and documented by DOE technical waste experts. Those reports are sent to the Site Project Manager and DOE Project Manager. As noted above under the mixed waste characterization activities for FY 1993, it was identified during an internal inspection that the LEHR RCRA Part A Permit Application did not accurately reflect the mixed waste stored at the LEHR. The California Department of Toxic Substance Control was notified of this finding and the LEHR is currently revising the RCRA Part A Permit Application to correct this inconsistency.

External Inspections -- No inspections were conducted by the EPA or the State of California during FY 1993.

Facility Uegrades or Modifications -- No upgrades or modifications to the mixed waste storage facility were conducted during FY 1993. 
Permit Modifications or Applications -- The LEHR RCRA Part A Permit Application is being revised to more accurately reflect the current status of LEHR's mixed waste, i.e., the change in the owner/operator and the addition of the new storage building.

\section{MIXED WASTE TREATMENT ACTIVITIES FOR FY 1993}

The LEHR does not have any mixed waste treatment facilities.

MIXED WASTE DISPOSAL ACTIVITIES FOR FY 1993

The LEHR does not have any mixed waste disposal facilities. 


\section{LAWRENCE BERKELEY LABORATORY \\ Berkeley, California}

Mission: The Lawrence Berkeley Laboratory (LBL), located in the Berkeley Hills of the San Francisco Bay Area, is a multiprogram taboratory primarily engaged in basic eneroy research such as high-energy physics, nuclear physics, heavy-ion fusion, magnetic fusion energy, biology, and medicine.

\section{RCRA COMPLIANCE AGREEMENTS OR ORDERS RELATING TO MIXED WASTE}

The LBL currently does not have any RCRA Compliance Agreements or Orders that relate to mixed waste.

\section{MIXED WASTE CHARACTERIZATION ACTIVITIES FOR FY 1993}

There were no activities conducted during FY 1993 to correct any past formal RCRA notifications of violations of waste characterization activities.

\section{MIXED WASTE STORAGE ACTIVITIES FOR FY 1993}

The LBL has seven storage units that can store mixed waste. The capacity for storing mixed waste in each unit is specified in LBL's new RCRA Part B permit issued May 4, 1993.

Internal Inspections -- The waste storage facility is inspected weekly by the Waste Management's Radioactive/Mixed Waste Operations Manager. A Compliance Specialist performs a monthly audit of the waste storage facility. The Compliance Specialist is responsible for ensuring all corrective actions take place. An interdisciplinary audit team inspects the facility quarterly. No significant compliance problems were identified during FY 1993 at the mixed waste storage facility.

External Inspections -- The California Department of Toxic Substances Control conducted an annual Compliance Evaluation Inspection, including the mixed waste storage and treatment units on March 11 and 12,1993 . No mixed waste related violations were alleged.

Facility Upgrades or Modifications -- As part of the new RCRA Part B permit issued on May 4, 1993, a series of upgrades to the mixed waste storage facility are required. These upgrades include the resealing of the mixed waste storage facility's floor, installing new mixed waste storage lockers, etc.

Permit Modifica Is or Applications -- The new RCRA Part B permit was issued on May 4, 1993.

\section{MIXED WASTE TREATMENT ACTIVITIES FOR FY 1993}

The LBL has two permitted mixed waste treatment units both of which are currently in standby status. These units are used for treatment of mixed low-level waste. 
Internal Inspections -- The mixed waste treatment units are inspected weekly by the Waste Management's Radioactive/Mixed Waste Operations Manager. A Compliance Specialist performs a monthly audit of the mixed waste treatment unit. The Compliance Specialist is responsible for ensuring all corrective actions take place. An interdisciplinary audit team inspects the facility quarterly. No significant compliance problems were identified during FY 1993 at the mixed waste treatment facilities.

External Inspections -- The California Department of Toxic Substances Control conducted an annual Compliance Evaluation Inspection, including the mixed waste storage and treatment units on March 11 and 12, 1993. No mixed waste related violations were alleged.

Facility Uparades or Modifications -- No upgrades or modifications to the mixed waste treatment units were conducted during FY 1993.

Permit Modifications or Applications -- The new RCRA Part B permit issued on May 4, 1993 allows for the treatment of mixed low-level waste at the two treatment units.

\section{MIXED WASTE DISPOSAL ACTIVITIES FOR FY 1993}

The LBL does not have any mixed waste disposal facilities. 


\section{LAWRENCE LIVERMORE NATIONAL LABORATORY Livermore, California}

Mission: The Lawrence Livermore National Laboratory ILLNL) was ostablished in 1952 to function as a national scientific and technical resource for the nuclear weapons program and other programs of national Interest. The LLNL performs research, development, and testing associated with the nuclear design aspects of all phases of the nuclear weapon life cycle. The LLNL consists of two noncontiguous parcels and is also involved in the following programs: inertial fusion, magnetic fusion, blomedical and envionmental research, lsotope separation; and applied eneroy technology and other research-related activities.

\section{RCRA COMPLIANCE AGREEMENTS OR ORDERS RELATING TO MIXED WASTE}

The LLNL currently does not have any RCRA Compliance Agreements or Orders that relate to mixed waste.

\section{MIXED WASTE CHARACTERIZATION ACTIVITIES FOR FY 1993}

There were no activities conducted during FY 1993 to correct any past formal notifications of RCRA violations of waste characterization activities.

\section{MIXED WASTE STORAGE ACTIVITIES FOR FY 1993}

The LLNL has 14 container storage units and two tank storage units located at the Main Site. All 14 of these units are currently operated under interim status and store mixed low-level waste. Four of the units also store mixed transuranic waste. The total design storage capacity for these units is $2,707 \mathrm{~m}^{3}$. The LLNL also has fourteen 90-day Waste Accumulation Area Facilities located at the Main Site and five 90-day Waste Accumulation Area Facilities located at the 300 Site. All of these Waste Accumulation Area Facilities store mixed low-level waste. Three of the Waste Accumulation Area Facilities at the Main Site also store mixed transuranic waste.

Internal Inspections -- Hazardous Waste Management Division operations technicians are trained to inspect the waste management units. Each facility has an inspection checklist which specifies the frequency of inspections, the areas to be inspected and the equipment to be inspected. All mixed waste container storage units and emergency equipment are inspected on a weekly basis. Any noncompliances found during the inspections are recorded on the inspection forms and a corrective action process is initiated. All corrective actions require a sign-off by the facility supervisor after the corrective action has been completed.

A self-assessment audit is conducted monthly of all mixed waste storage facilities. A report is generated indicating items of noncompliance. This report is sent to management personnel, including Hazardous Waste Division management, the Department Head and the Associate Director. The Operations Management of the mixed waste storage facilities is responsible for closing-out the findings. No significant compliance problems were identified during FY 1993 at the mixed waste storage facilities. 
External Inspections -- The State of Califonia's Department of Toxic Substances Control conducted two Compliance Evaluation Inspections, one at the Main Site and the other at Site 300 during FY 1993.

Facility Uporades or Modifications -- Plans are underway to upgrade or modify four of the mixed waste container storage units. One unit will be upgraded to permitted container storage unit requirements, the second one will have addition of a sprinkler system, the third one will have addition of a sprinkler system and cell separation walls, and the last one will have the addition of a decontamination, size reduction, and waste certification walk in hood.

Permit Modifications or Applications -- A revised RCRA Part B Permit Application for LLNL's Main Site (dated April 20, 1993) was submitted to the California Department of Toxic Substance Control for approval. The revised application is currently under review by the California Department of Toxic Substance Control.

\section{MIXED WASTE TREATMENT ACTIVITIES FOR FY 1993}

The LLNL has five mixed waste treatment facilities located at the Main Site and none at Site 300. All five of these facilities currently have interim status. Four of these facilities are currently operating and one facility is under construction. All four of the operating facilities treat mixed low-level waste; three of these facilities can also treat mixed transuranic waste. The facility under construction will be able to treat both mixed low-level waste and mixed transuranic waste.

Internal Inspections -- All treatment units that process mixed waste are inspected on a daily basis. The loading, unloading, staging areas, and miscellaneous treatment units are inspected daily when in use for spills and damaged containers. A self-assessment audit of the treatment facilities is conducted monthly. The procedures and persons responsible for the inspections is the same for the treatment facilities as that discussed above for the storage facilities. No significant compliance problems were identified during FY 1993 at the mixed waste treatment facilities.

External Inspections -- The State of Califonia's Department of Toxic Substances Control conducted two Compliance Evaluation Inspections, one at the Main Site and the other at Site 300 during FY 1993.

Facility Uparades or Modifications -- The mixed waste solidification unit was installed at one of the treatment facilities.

Permit Modifications or Applications -- A revised RCRA Part B Permit Application for LLNL's Main Site (dated April 30, 1993) was submitted to the California Department of Toxic Substance Control for approval. The revised application is currently under review by the California Department of Toxic Substance Control.

\section{MIXED WASTE DISPOSAL ACTIVITIES FOR FY 1993}

The LLNL does not have any mixed waste disposal facilities. 


\section{MARE ISLAND NAVAL SHIPYARD \\ Vallejo, California}

Mission: The Mare Island Naval Shipyard is a U,S. Navy facility that repairs, overhauls, and maintains Navy ships, including nuclear-powered ships. Drydocks, cranes, waste-handling facillties, and offices are tocated at the shipyard. Activities supporting nuclear power propulsion systems are performed in accordance with the requirements and authorlty of the Naval Nuclear Propulsion Program, a joint DOE and Department of Navy program responsible for all actividies relating to naval nuclear propulsion.

\section{RCRA COMPLIANCE AGREEMENTS OR ORDERS RELATING TO MIXED WASTE}

The Mare Island Naval Shipyard currently does not have any RCRA Compliance Agreements or Orders relating to mixed waste.

\section{MIXED WASTE CHARACTERIZATION ACTIVITIES FOR FY 1993}

There were no activities conducted during FY 1993 to correct any past formal notifications of RCRA violations of waste characterization activities.

\section{MIXED WASTE STORAGE ACTIVITIES FOR FY 1993}

The Mare Island Naval Shipyard has one mixed waste storage facility that stores mixed low.level waste. This facility is operated under interim status and has the capacity to store $65 \mathrm{~m}^{3}$ of waste.

Internal Inspections -- The mixed waste storage facility is inspected weekly by the waste handling personnel. Regulatory compliance is monitored by the Environmental Compliance Branch who performs quarterly inspections of the facility and yearly audits of the mixed waste program. Any deficiencies are documented and tracked on the Mare Island Naval Shipyard's environmental deficiency data base. No significant compliance problems were identified during FY 1993 at the mixed waste storage facility.

External Inspections -- The California Department of Toxic Substance Control conducted a routine inspection of the mixed waste storage facility on June 2, 1993. No violations were alleged.

Facility Uparades or Modifications -- The storage area within the mixed waste storage facility was enlarged during FY 1993.

Permit Modifications or Applications -- No RCRA permit modifications or applications relating to mixed waste were submitted during FY 1993.

\section{MIXED WASTE TREATMENT ACTIVITIES FOR FY 1993}

The Mare Island Naval Shipyard does not have any mixed waste treatment facilities.

\section{MIXED WASTE DISPOSAL ACTIVITIES FOR FY 1993}

The Mare Island Naval Shipyard does not have any mixed waste disposal facilities. 


\section{SANDIA NATIONAL LABORATORY/CALIFORNIA Livermore, California}

Mission: Established in 1956 to provide support services to the nelohboring Lawrence Livermore National Laboratory, Sandia National Laboratories/California's (SNL/CA) initial mission was to provide ordnance engineering services to Lawrence Livermore National Laboratory. Current programs being carried out at SNL/CA include nuclear weapons systems development and combustion, solar, and fusion research. The site was initially developed by the U.S. Navy in 1942 and transferred to DOE In 1956 .

\section{RCRA COMPLIANCE AGREEMENTS OR ORDERS RELATING TO MIXED WASTE}

The SNL/CA currently does not have any RCRA Compliance Agreements or Orders relating to mixed waste.

\section{MIXED WASTE CHARACTERIZATION ACTIVITIES FOR FY 1993}

There were no activities conducted during FY 1993 to correct any past formal notifications of RCRA violations of waste characterization activities.

\section{MIXED WASTE STORAGE ACTIVITIES FOR FY 1993}

The SNL/CA has one waste storage facility that stores mixed low-level waste. This facility has the capacity to store up to 500 gallons $\left(2 \mathrm{~m}^{3}\right)$ of waste.

Internal Inspections -- The mixed waste storage facility is inspected weekly by a Radioactive Waste Representative. Any noncompliances are reported to Waste Management and the Kirtland Area Office. No significant compliance problems were identified during FY 1993 at the mixed waste storage facility.

External Inspections -- The State of California EPA inspected the mixed waste storage facility in January 1993. No mixed waste findings were identified.

Facility Uparades or Modifications -- During FY 1993 the floors of the mixed waste storage facility were recoated with chemical resistant epoxy.

Permit Modifications or Applications -- The SNL/CA received its RCRA Part B permit in January 1993.

\section{MIXED WASTE TREATMENT ACTIVITIES FOR FY 1993}

The SNL/CA does not have any mixed waste treatment facilities.

\section{MIXED WASTE DISPOSAL ACTIVITIES FOR FY 1993}

The SNL/CA does not have any mixed waste disposal facilities. 


\section{0वษ80า0ว}


This page intentionally left blank. 


\section{GRAND JUNCTION PROJECTS OFFICE \\ Grand Junction, Colorado}

Mission: The present Grand Junction Projects Office site was acquired by the U.S. War Department in 1943 in support of the Manhattan Engineer District. The historical mission of the Grand Junction Projects Office was uranium milline, analyses, and storage. The facility currently supports the U.S. Department of Energy's remedial action propram.

\section{RCRA COMPLIANCE AGREEMENT OR ORDERS RELATING TO MIXED WASTE}

The Grand Junction Projects Office currently does not have any RCRA Compliance Agreements or Orders that relate to mixed waste.

\section{MIXED WASTE CHARACTERIZATION ACTIVITIES FOR FY 1993}

There were no activities conducted during FY 1993 to correct any past formal notifications of RCRA violations of waste characterization activities.

\section{MIXED WASTE STORAGE ACTIVITIES FOR FY 1993}

The Grand Junction Projects Office has one mixed waste storage facility that stores mixed low-level waste. This storage facility has the capacity to store $\mathbf{2 4 0 0}$ gallons of mixed waste.

Internal Inspections -- The mixed waste storage facility is inspected weekly by the Waste Management subsection. The Manager of Environmental Services is notified of any findings identified during these inspections. A formal tracking system is used to track the status of significant findings. No significant compliance problems were identified during FY 1993 at the mixed waste storage facility.

External Inspections -- No inspections were conducted by the EPA or the State of Colorado during FY 1993.

Facility Upgrades or Modifications -- The mixed waste storage facility was modified by adding modular storage facilities.

Permit Modifications or Applications -- No RCRA permit modifications or applications relating to mixed waste were submitted during FY 1993.

\section{MIXED WASTE TREATMENT ACTIVITIES FOR FY 1993}

The Grand Junction Projects Office does not have any mixed waste treatment facilities.

\section{MIXED WASTE DISPOSAL ACTIVITIES FOR FY 1993}

The Grand Junction Projects Office does not have any mixed waste disposal facilities. 


\section{ROCKY FLATS PLANT \\ Rocky Flats, Colorado}

Mission: The Pocky Flats Plant is located 40 kllometers northwest of Denver, Colorado, and occuples approximately 25 square kilometers. The Rocky Flats Plant began operation in 1952, and its historical mission was to produce plutonium and other motal components for nuclear weapons. This mission has been eliminated, and remaining weapon production needs are to be transferred to other facilities. The current mission of the plant is 11 to maintain the plant in a safe condition; 2) to ensure compliance with all environmental regulations and requirements including those for mixed waste management; 3) to safeguard the stockpile of special nuclear material onsite; 4 ) to continue the environmental restoration effort; and 5) to transition the plant from its production mission to decontamination and decommissionino and economic development.

\section{RCRA COMPLIANCE AGREEMENTS OR ORDERS RELATING TO MIXED WASTE}

The Rocky Flats Plant has three agreements or orders relating to the management of mixed waste that were effective during FY 1993. These include the following:

- $\quad$ Land Disposal Restriction (LDR) Federal Facility Compliance Agreement

- $\quad$ Effective date May 10, 1991

- Termination date May 10, 1993

- Negotiated between the DOE and the EPA

- $\quad$ Addresses LDR issues under RCRA

- Residue Settlement Agreement and Compliance Order on Consent 93-04-23-01

- Effective date June 17, 1993

- Termination date Indefinite

- Negotiated among the DOE, EG\&G and the Colorado Department of Health

- Addresses physical and administrative compliance for mixed residues under RCRA

- Residue Compliance Order 91-07-31-01

- $\quad$ Effective date July 31, 1991

- Termination date June 17, 1993

- : Issued to the DOE by the Colorado Department of Health

- $\quad$ Superseded by Compliance Order 93-04-23-01 above

The Rocky Flats Plant has two agreements or orders relating to the management of mixed waste that have been under negotiation during FY 1993. These include the following:

- $\quad$ LDR Federal Facility Compliance Agreement

- $\quad$ Negotiation started June 1992

- Expected signatories include the DOE, EG\&G, the EPA, and the Colorado Department of Health

- $\quad$ Finalization may be complicated by the FFCAct 
June 17, 1992 Notice of Violation Consent Order

Negotiation started November 1992

Expected signatories include EG\&G and the Colorado Department of Health

56 counts that address training, characterization and nther compliance issues under RCRA

\section{MIXED WASTE CHARACTERIZATION ACTIVITIES FOR FY 1993}

Three major initiatives have been undertaken during FY 1993 related to waste characterization and correction of environmental deficiencies. Two of these initiatives resulted from problems identified during internal self-evaluations and one was identified by the Colorado Department of Health.

During an internal self-evaluation, a variety of containers were discovered in an excess property storage yard that had inadequate characterization information to ensure proper storage of the material. Containers were sampled and analyzed to obtain information regarding the content of the containers. This initiative is now complete and the materials are properly stored.

As part of the internal self-evaluation, it was noted that a waste container that possessed EPA hazardous waste codes not authorized for the unit was processed through the new Supercompactor. The root cause of the event resulted from less than adequate controls surrounding recharacterization of waste containers already in storage (a.k.a. "backlog" waste). Corrective action plans were put in place and are currently being followed to ensure that all re-characterization of "backlog" waste is accurately reflected on the container documentation and the Rocky Flats Plant RCRA operating record.

The Colorado Department of Health discovered several containers of excess chemicals and unknown compounds in one of the 90-day accumulation areas for which hazardous determinations had not been made. It was imperative that the chemicals and unknowns be adequately characterized in order to meet deadlines imposed by the Colorado Department of Health. Both onsite and offsite laboratories were utilized for the characterization analysis. The characterization has been completed and the chemicals packaged and stored in accordance with all state and federal regulations.

Both internal and external evaluations have identified characterization deficiencies for excess chemicals and other materials for which there is presently no identified need or use. In many instances, those excess chemicals and materials have not been adequately characterized in accordance with RCRA requirements. The Rocky Flats Plant is undertaking an inventory of these types of materials to be completed in December, 1993. The inventory will be used to identify the location and quantity of materials in question and to develop an action plan to properly characterize and dispose of these materials.

\section{MIXED WASTE STORAGE ACTIVITIES FOR FY 1993}

The Rocky Flats Plant has $\mathbf{2 6 7}$ waste storage units that store mixed waste including mixed low-level waste, mixed transuranic waste, and/or mixed residues. Three of these storage units will be closed under interim status. The remaining storage units have the total capacity to store over 3,985,000 gallons and over $34,000 \mathrm{yd}^{3}$ of mixid waste. In addition, the Rocky Flats Plant has numerous satellite accumulation and 90-day storage areas.

Internal Inspections -- The mixed waste storage units are inspected weekly by the Waste Custodian of the storage unit. Any noncompliances identified during these inspections are corrected within 24 hours of discovery. In the event this time frame can not be met, a longer term action plan is developed 
that outlines the mechanism(s) for correcting the deficiency. These action plans are entered into the Plant Action Tracking System. All compliance deficiencies are reported informally to the Colorado Department of Health via facsimile. The status of longer term corrective actions for compliance deficiencies are transmitted informally to the Colorado Department of Health monthly via the Plant Action Tracking System updates and the Monthly Environmental Compliance Report. During an inspection conducted in FY 1993, it was noted that the contingency plan had not been properly implemented. Specifically, there were four instances when a release of a hazardous waste to secondary containment had not been removed within the 24-hour time frame. These four regulatory requirement deficiencies were reported to the Colorado Department of Health during FY 1993.

External Inspections -- The Colorado Department of Health has conducted 30 separate inspections of the mixed waste storage units during FY 1993. Four of these inspections were conducted in conjunction with the EPA Region VIII. The EPA Region VIII also conducted one inspection without the Colorado Department of Health. No Notices of Violations were issued.

Two separate activities have been conducted at the Rocky Flats Plant during FY 1993 to correct past RCRA violations identified during external inspections. These activities occurred in two main areas. The first one was related to the Notice of Violation issued on June 17, 1992 by the State of Colorado Department of Health to EG\&G, 18 Corrective Action Plans were generated by EG\&G to address the alleged violations. The 18 Corrective Action Plans were written to respond to the Rocky Flat's Office direction (Ten Point Action Plan) to address the causes of the ongoing problems with RCRA compliance. The Corrective Action Plans deal primarily with inadequately trained employees, prioritization of environmental corrective actions, development of performance indicators and responsibilities, corrective action tracking and trending, and waste characterization. Detailed information about each Action Plan is available in either the Plant Action Tracking System or in the Rocky Flats Plant Hazardous Waste and Self-Assessment Action Plan transmitted to DOE, Rocky Flats Operations Office on August 24, 1992.

The June 17, 1992 Notice of Violation Draft Settlement Agreement requires the Rocky Flats Plant to prepare a Hazardous Waste Environmental Compliance Program Plan, to be fully implemented by the end of Calendar Year 1994. The draft Hazardous Waste Environmental Compliance Program Plan was submitted to the Colorado Department of Health in August, 1993. The draft plan is under review by the Rocky Flats Office and will require revision. Many corrective actions in the draft plan are underway and some have been successfully completed.

The second involved a significant effort to achieve physical and administrative RCRA compliance for mixed residues as specified in the Residue Compliance Order las further defined in the Residue Compliance Plan). The activities undertaken included all actions necessary to comply with the requirements of the Colorado Hazardous Waste Regulations. Primary activities included provisions for secondary containment (e.g., painting, berm construction); evaluating, repairing and documenting adequacy of ancillary equipment; verification of inventory; corrective actions for surveillance findings (e.g., placement of markings, label, signs); performance of surveillances on all "future" permitted residue units; and verification of "operationally empty" units destined for closure.

Facility Upgrades or Modifications -- Facility upgrades or modifications to the mixed waste storage units conducted during FY 1993 were a result of an external inspection finding. This is discussed in the section above under external inspections. 
Permit Modifications or Apolications -. The Rocky Flats Plant submitted the following permit modifications and revisions to the Colorado Department of Health during FY 1993:

- On November 6, 1992, permit modification request \# 12, a Class III modification for several interim status units. This request included the Supercompactor, Transuranic Waste Shredder, Pondcrete/Saltcrete storage and treatment facilities as well as storage and treatment facilities related to Environmental Restoration activities. The approval of this modification is still pending.

- On November 13,1992, a justification letter as part of a request for change to interim status (Part A, Revision 4) to add various EPA waste codes. The Colorado Department of Health granted a partial change to interim status on March 4, 1993.

- On April 8, 1993, a draft revised RCRA permit which incorporates several modifications. This draft is an effort to expedite updating the RCRA permit. The Colorado Department of Health issuance of the revised permit is pending.

On May 18, 1993, a change to interim status (Part A, Revision 11) requesting designation of the pondcrete and saltcrete "triwalls" in the 904 Pad container storage area as waste pile storage. The Colorado Department of Health approval is pending.

- On June 30, 1993, an application to apply the National Pollution Discharge Elimination System permit wastewater treatment exception to certain wastewater treatment units (Liquid Waste Treatment Facilities) which have interim status. By applying this exception, these units would not need RCRA permits and certain wastewaters would no longer be hazardous wastes. The approval of this application is pending.

- On August 6, 1993, a permit modification request \#15 was submitted which updated permit modification request $\# 8$, submitted on June 30, 1992 for mixed residues. The modification request added one mixed residue storage tank previously considered empty, and proposed closure, rather than upgrades for some tanks no longer needed for hazardous waste operations. The modification also requested minor changes based upon ongoing field work.

\section{MIXED WASTE TREATMENT ACTIVITIES FOR FY 1993}

The Rocky Flats Plant has 21 mixed waste treatment units. Twelve of these units (three of which will be closed unider interim status) treat or have treated mixed low-level waste; one of these units treats only mixed transuranic waste; five of these units treat both mixed low-level and mixed transuranic waste; and three of these units treat mixed residues, and mixed low-level and mixed transuranic waste.

Not all of the mixed waste treatment units are currently operational and none are currently capable of treating mixed wastes to meet Land Disposal Restriction treatment standards and/or all waste acceptance criteria.

Internal Inspections -- The mixed waste treatment units are inspected weekly by the Waste Custodian of the treatment unit. Any noncompliances identified during these inspections are corrected within 24 hours of discovery. In the event this time frame can not be met, a longer term action plan is developed that outlines the mechanism(s) for correcting the deficiency. 
These action plans are entered into the Plant Action Tracking System. The status of longer term corrective actions for compliance deficiencies are transmitted informally to the Colorado Department of Health monthly via the Plant Action Tracking System updates and the Monthly Environmental Compliance Report. No significant compliance problems were identified during FY 1993 at the mixed waste treatment units.

External Inspections -- The State of Colorado Department of Health has conducted 16 separate inspections of the mixed waste treatment units during FY 1993. Two of these inspections were also conducted in conjunction with the EPA Region VIII. No Notices of Violations were issued.

Facility Uparades or Modifications -- During FY 1993 activities to upgrade the Building 374 Evaporator/Liquid Waste Treatment Facility was initiated. This activity is still ongoing.

Permit Modifications or Apolications -- All permit modifications or applications submitted by the Rocky Flats Plant during FY 1993 are listed above under the permit modification or applications section for mixed waste storage activities.

\section{MIXED WASTE DISPOSAL ACTIVITIES FOR FY 1993}

The Rocky Flats Plant does not have any permitted mixed waste disposal facilities. 


\section{FLORIDA}


This page int3ntionally left blank. 


\section{PINELLAS PLANT}

Laroo, Forida

Mission: The primary mission of the Pinellas Plant is the design, development, and manufacture of special electronic and mechanical nuclear weapons components, such as neutron-generating devices, neutron detectors, and associated product testers. Other work involves electronic, ceramic, and high-vacuum technology. The Pinellas Plant has been in continuous use since 1957.

\section{RCRA COMPLIANCE AGREEMENTS OR ORDERS RELATING TO MIXED WASTE}

The Pinellas Plant currently does not have any RCRA Compliance Agreements or Orders that relate to mixed waste.

\section{MIXED WASTE CHARACTERIZATION ACTIVITIES FOR FY 1993}

There were no activities conducted during FY 1993 to correct any past formal notifications of RCRA violations of waste characterization activities.

\section{MIXED WASTE STORAGE ACTIVITIES}

The Pinellas Plant has one storage facility that can store mixed low-level waste. This facility is a permitted facility and has the capacity to store 3855 -gallon drums of mixed waste. At present, no mixed waste is stored at this facility. The Pinellas Plant also has a satellite accumulation area which currently stores mixed low-level waste.

Internal Inspections -- The waste storage facility is inspected daily by waste management personnel when waste is being stored. No mixed waste is currently being stored in the permitted facility and no compliance issues exist. The satellite accumulation area is inspected as part of the Pinellas Plant Environmental Assessment Program. Assessments are conducted twice a year. Any noncompliances identified during these inspections are reported to Martin Marietta management and Pinellas Area Office personnel. The Pinellas Area Office notifies the appropriate State of Florida agency of the noncompliance. No significant compliance problems were identified during FY 1993 at the waste storage facility.

External Inspections -- The Florida Department of Environmental Protection conducted a compliance inspection on April 30, 1993 of the waste storage facility. No mixed waste was stored at the facility during the time of the inspection.

Facility Upgrades or Modifications -- No upgrades or modifications to the waste storage facility were conducted during FY 1993.

Permit Modifications or Applications -- The Pinellas Plant submitted a RCRA Part B Permit Renewal Application to the Florida Department of Environmental Protection on April 1, 1993. The Pinellas Plant is currently addressing comments provided by the Florida Department of Environmental Protection with responses due by October 14, 1993. 
MIXED WASTE TREATMENT ACTIVITIES

The Pinellas Plant does not have any mixed waste treatment facilities.

\section{MIXED WASTE DISPOSAL ACTIVITIES}

The Pinellas Plant does not have any mixed waste disposal facilities. 


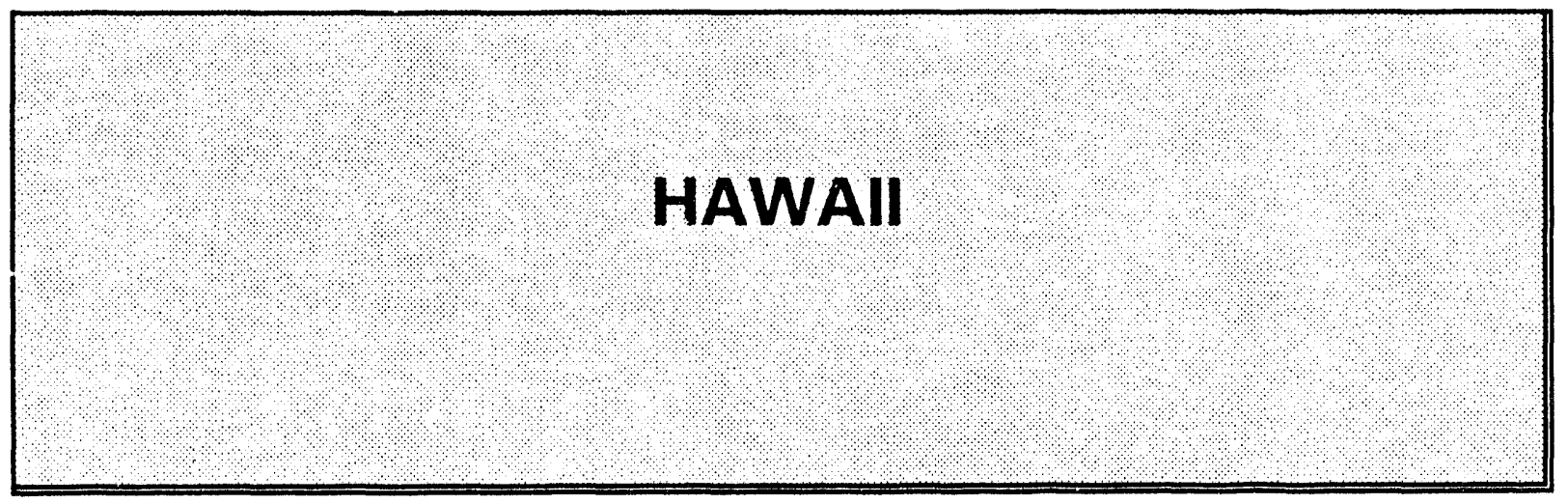


This page intentionally left blank.

CHIEF FINANCIAL OFFICER'S REPORT-1993

A-28 


\section{PEARL HARBOR NAVAL SHIPYARD \\ Honolulu, Hawaii}

Mission: The Pearl Harbor Naval Shipyard is a U.S. Department of Navy facility that repairs, overhauls, and maintains Navy ships, Including nuclear-powered ships. Drydocks, cranes, wastehandling facilities, and offices are located at the shipyard., Activities supporting nuclear propulsion systems are performed in accordance with the requirements and authority of the Naval Nuclear Propulsion Program, a joint DOE and U.S. Department of Navy propram responsible for all activities relating to naval nuclear propulsion.

\section{RCRA COMPLIANCE AGREEMENTS OR ORDERS RELATING TO MIXED WASTE}

The Pearl Harbor Naval Shipyard currently does not have any RCRA Compliance Agreements or Orders that relate to mixed waste.

\section{MIXED WASTE CHARACTERIZATION ACTIVITIES FOR FY 1993}

There were no activities conducted during FY 1993 to correct any past formal notifications of RCRA violations of waste characterization activities.

\section{MIXED WASTE STORAGE ACTIVITIES}

The Pearl Harbor Naval Shipyard has one facility that stores mixed low-level waste. This facility has the capacity to store $66 \mathrm{~m}^{3}$ of waste and is currently operated under interim status.

Internal Inspections -- The mixed waste storage facility is inspected weekly, monthly, and following each entry by a Custodian Shop employee. A quarterly surveillance inspection is conducted by the Environmental Division and both the Environmental Division and the Radiological Controls Office perform yearly audits. Any noncompliances identified during these inspections are documented and maintained and a report is issued following the yearly audit. No significant compliance problems were identified during FY 1993 at the mixed waste storage facility.

External Inspections -- No inspections by the EPA or the State of Hawaii were conducted during FY 1993.

Facility Upgrades or Modifications -- The Pearl Harbor Naval Shipyard mixed waste storage area was expanded in March 1993 to accommodate a hazardous waste bin to store flammable waste.

Permit Modifications or Applications -- No RCRA permit modifications or applications relating to mixed waste were submitted during FY 1993.

\section{MIXED WASTE TREATMENT ACTIVITIES}

The Pearl Harbor Naval Shipyard does not have any mixed waste treatment facilities.

\section{MIXED WASTE DISPOSAL ACTIVITIES}

The Pearl Harbor Naval Shipyard does not have any mixed waste disposal facilities. 
This page intentionally left blank. 


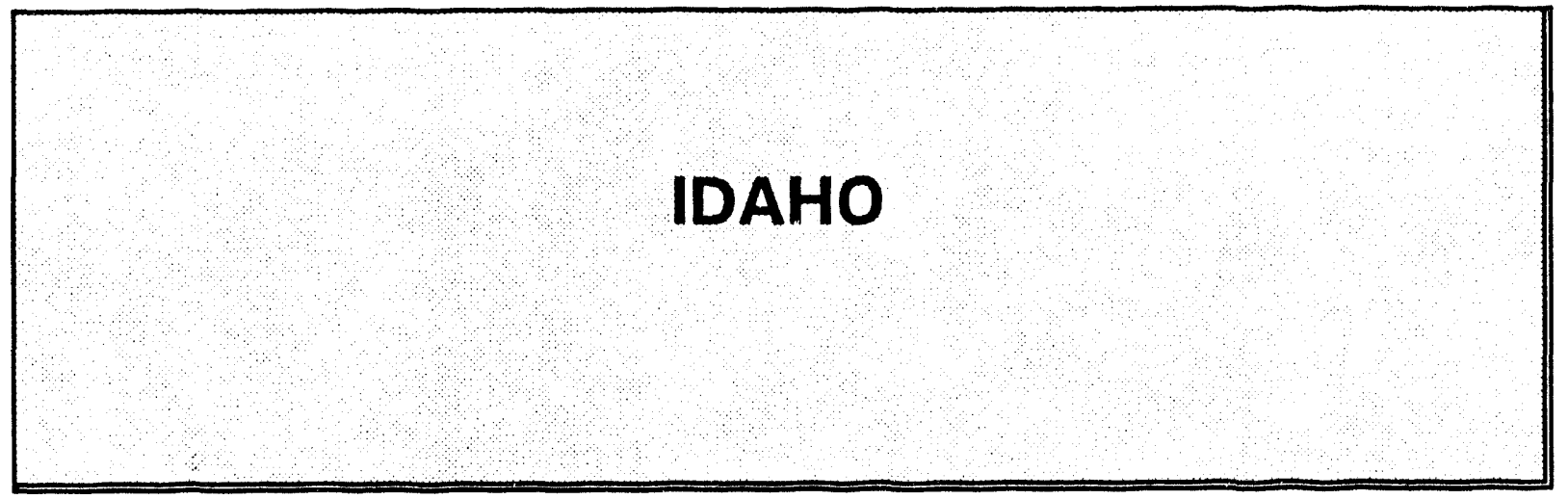


This page intentionally left blank. 


\section{ARGONNE NATIONAL LABORATORY-WEST \\ Idaho Falls, Idaho}

Mission: The primary mission of Argonne National Laboratory-West (ANL-W) is research and development in support of the nation's fast-reactor program. The ANL-W operates the following facilities at the Idaho National Engineering Laboratory: the Experimental Breeder Reactor II, the Transient Reactor Test Facility, the Zero Power Physics Reactor, the Hot Fuel Examination Facility, the Fuel Cycle Facility, and the Fuel Manufacturing Facility and Laboratory. The ANL-W is located on the southeastern portion of the Idaho National Engineering Laboratory.

\section{RCRA COMPLIANCE AGREEMENTS OR ORDERS RELATING TO MIXED WASTE}

The ANL-W is participating with the DOE Idaho Office in the Land Disposal Restrictions Consent Order between Idaho National Engineering Laboratory and the State of Idaho.

\section{MIXED WASTE CHARACTERIZATION ACTIVITIES FOR FY 1993}

There were no activities conducted during FY 1993 to correct any past formal notifications of RCRA violations of waste characterization activities.

\section{MIXED WASTE STORAGE ACTIVITIES}

The ANL-W has three mixed waste storage facilities (Radioactive Sodium Storage Facility, Hot Fuel Examination Area-WIPP Waste Characterization, Radioactive Scrap and Waste Facility) that store mixed low-level and mixed transuranic waste. These facilities have the capacity to store $235 \mathrm{~m}^{3}$ of mixed waste and are currently operated under interim status. Because the wastes stored at one of the storage facilities are highly radioactive, this facility contains many rows of vertically oriented steel-lined soil vaults. The soil provides adequate shielding of radiation fields associated with the wastes.

Internal Inspections -- The overall inspection program for the Radioactive Sodium Storage Facility is implemented by three separate groups within ANL-W. They include the Radiation, Fire and Safety personnel; the ANL-W Plant Services Group; and the Life Safety Systems Group. Although the frequencies of inspections among these three groups differ, all items located at the facility receive multiple inspections every month. During inspection, all items requiring attention are noted on an inspection log sheet. The inspector, as part of the continuing inspection process, checks to ensure that all items previously noted have been satisfactorily. resolved.

The Hot Fuel Examination Area-WIPP Waste Characterization facility is inspected daily when waste operations are in progress or waste is stored in the facility. The Waste Engineer (or a designated alternate) reviews all inspection log sheets on a weekly basis. Deficiencies noted as a result of an inspection will be corrected by the Waste Engineer or a designated alternate.

The Radioactive Scrap and Waste Facility, which is underground, is inspected weekly, monthly semiannually and annually. These inspections focus on the maintenance of the liners through the use of cathodic protection, visual inspection, ultrasound, and radiation surveys. 
No significant compliance problems were identified during FY 1993 at these mixed waste storage facilities.

External Inspections -- The State of Idaho conducted an annual RCRA inspection of the mixed waste storage facilities during September 15-17, 1993. No violations were alleged.

Eacility Uparades or Medifications -- During FY 1993 the ANL-W continued work on the installation of a cathodic protection system for steel waste storage vaults and installed new liners at the Radioactive Scrap and Waste Facility. The ANL-W also upgraded the Hot Fuel Examination Area-WIPP Waste Characterization facility to provide secondary spill containment in two storage areas.

Permit Modifications or Applications -- Modifications to the RCRA Part A and Part B Permit Application are required for the Radioactive Sodium Storage Facility. The modifications will include a request to increase the facility's maximum storage capacity and add RCRA waste codes. Additional mixed wastes that will be stored at this facility will also be described.

\section{MIXED WASTE TREATMENT ACTIVITIES}

The ANL-W does not have any mixed waste treatment facilities.

\section{MIXED WASTE DISPOSAL ACTIVITIES}

The ANL-W does not have any mixed waste disposal facilities. 


\section{IDAHO NATIONAL ENGINEERING LABORATORY \\ Idaho alls, Idaho}

Mission: The Idaho National Engineering Laboratory was established in 1949 by the U.S. Atomic Energy Commission as an area to build, test, and operate various nuclear reactors, fuel processing plants, and support facilities with maximum safety and isolation. Originally known as the Nationa! Reactor Testing Station, the site was renamed as the Idaho National Engineering Laboratory in 1974 to reflect the broad scope of engineering activities now conducted at the site. Prior to its establishment, the site was used as a World War II gunnery range by the U.S. Navy and U.S. Army Air Corps.

\section{RCRA COMPLIANCE AGREEMENTS OR ORDERS RELATING TO MIXED WASTE}

The Idaho National Engineering Laboratory has two consent orders issued by the State of Idaho relating to the management of mixed waste that were effective during FY 1993. These include the following:

- $\quad$ Consent Order for Notice of Non-Compliance

- Effective date April 3, 1992

- Addresses various mixed waste issues including mixed waste storage

- Consent Order for Notice of Violation

- Effoctive date October 7, 1992

- Addresses various mixed waste issues including mixed waste characterization

- Notice of Violation

- Issued February 2, 1993

- Undergoing negotiations

- Principle issue is storage procedures of mixed waste samples in laboratories

In addition, the Idaho National Engineering Laboratory has one consent order under negotiation with the State of Idaho relating to the management of Land Disposal Restriction mixed waste in accordance with the FFCAct. This negotiation period with the State of Idaho is expected to extend from FY 1993 to FY 1995. This order will address three issues including: compliance with the Land Disposal Restrictions-storage prohibitions, storage of transuranic waste under earthen cover, and the storage of sodium/potassium solution in the Army Reentry Vehicle Facility Site storage facility. These negotiations are proceeding as part of the development of the Idaho Site Treatment Plan.

\section{MIXED WASTE CHARACTERIZATION ACTIVITIES FOR FY 1993}

The Idaho National Engineering Laboratory completed characterization of 29 radioactive soil samples in storage at one of the mixed waste storage facilities during FY 1993. This characterization was a result of the Notice of Violation issued for the May 18, 1992 RCRA inspection by the State of Idaho Division of Environmental Quality. 


\section{MIXED WASTE STORAGE ACTIVITIES FOR FY 1993}

The Idaho National Engineering Laboratory currently operates 25 mixed waste storage facilities with a total capacity of $247,530 \mathrm{~m}^{3}$. This capacity is used for storage of mixed low-level waste, mixed transuranic waste, and high-level waste. All of these facilities are operated under interim status. There are two storage facilities for which interim status has been requested; one is for mixed low-level waste and one is for high-level waste. The Idaho National Engineering Laboratory also has numerous satellite accumulation areas and less than 90-day storage facilities. Some of the storage facilities at the Idaho National Engineering Laboratory require the use of remote handling equipment because of the levels of radioactivity in the wastes.

Internal Inspections -- Mixed waste storage facilities are inspected by the operating contractor personnel on a regular basis either daily, weekly or monthly, as specified in the individual facility RCRA inspection plans. Notification procedures for compliance deficiencies vary dependant on the severity and urgency of the finding. For instance, where a spill or leak is found the emergency/RCRA contingency plan is implemented. If a non-compliant situation does not require immediate action, it is noted on the facility discrepancy, inspection, or operating log and follow up action is implemented. Additionally, the Idaho National Engineering Laboratory has several internal groups that conduct regular compliance inspections or audits. These internal groups include the environmental auditors within the contractor's environmental organization, the performance evaluation personnel, and quality assurance and quality verifications staff.

The lack of visual inspection capability for the two earthen covered storage facilities have been subject to continuing internal audit finding and discussion with the State of Idaho regulators over the years. Current plans are to resolve these issues during the negotiations for the Site Treatment Plan Consent Order with the State of Idaho.

External Inspections -- The State of Idaho conducted an annual routine RCRA facility inspection during the week of September $13-17,1993$. Results from this inspection are not expected to be provided to the Idaho National Engineering Laboratory until next year.

Activities have been conducted at the Idaho National Engineering Laboratory during FY 1993 to correct past RCRA violations identified during external inspections. Activities conducted during FY 1993 to meet the requirements established in the Notice of Non-Compliance Consent Order signed on April 3 , 1992 , included continued construction of the new waste storage facility buildings that will allow proper inspection and movement of emergency personnel and equipment; installation and upgrade to the leak detection system located in one of the storage facilities (completed June, 1993); and completion and certification by a professional engineer of all secondary containment requirements for two of the waste storage tanks (completed June 28, 1993).

Facility Upgrades or Modifications -- In addition to the upgrades and modifications that were conducted during FY 1993 as a result of an external inspection findings, addressed in the previous section, the Idaho National Engineering Laboratory has two other projects. Construction of the Waste Experimental Reduction Facility waste storage building was completed and upgrades to the Intermediate-Level Transuranic Storage Facility vaults are ongoing to provide radiation monitoring and video equipment to provide visual inspection capability. The transuranic wastes are currently stored in a dense pack configuration (without aisle space) to provide self-shielding to maintain potential radiation exposure as low as reasonably achievable which make normal visual inspections not feasible. 
Permit Modifications or Apolications -- The Idaho National Engineering Laboratory submitted RCRA Part B Permit Applications for ten separate mixed waste facilities to the State of Idaho during FY 1993. These applications are still pending and are in various stages of review with the State of Idaho.

One of these applications for two storage units has been deemed technically complete, has been reviewed by the public, and a draft permit was received from the State of Idaho. RCRA Interim Status has been requested from the State of Idaho for two other mixed waste storage facilities.

The Idaho National Engineering Laboratory submitted several RCRA Part A Permit amendments to the Idaho Department of Environmental Quality during FY 1993. None of these applications have yet received a response.

\section{MIXED WASTE TREATMENT ACTIVITIES FOR FY 1993}

The Idaho National Engineering Laboratory has 16 active or anticipated mixed low-level waste treatment facilities under interim status and one for which interim status has been requested. Six other facilities will be closed under interim status. The Idaho National Engineering Laboratory has two treatment facilities for the treatment of high-level waste.

Internal Inspections -- Mixed waste treatment facilities are inspected by the operating contractor personnel on a regular basis either daily, weekly or monthly, as specified in the individual facility RCRA inspection plans. Notification procedures for compliance deficiencies vary dependant on the severity and urgency of the finding. The RCRA emergency/contingency plan is implemented if a finding requires immediate attention. If a non-compliant situation does not require immediate action, it is noted on the facility discrepancy, inspection, or operating $\mathrm{log}$ and follow up action is implemented. Additionally the Idaho National Engineering Laboratory has several internal groups that conduct regular compliance inspections or audits. Additionally, the Idaho National Engineering Laboratory has several internal groups that conduct regular compliance inspections or audits. No significant compliance problems were identified during FY 1993 at the mixed waste treatment facilities.

External Inspections -- The State of Idaho conducted an annual routine RCRA facility inspection during the week of September $13-17,1993$. Results from this inspection are not expected to be provided to the Idaho National Engineering Laboratory until next year.

A new mixed waste treatment facility commenced operation March 20, 1993. This activity was required by the April 3, 1992 Consent Order for the Notice of Non-Compliance.

Facility Upgrades or Modifications -- The Idaho National Engineering Laboratory completed construction and began operation of a mixed waste treatment facility in order to discontinue discharge of mixed waste to the Idaho Chemical Processing Plant percolation ponds. Upgrades at another treatment facility are underway to allow treatment of existing mixed waste and then closure of the unit.

Permit Modifications or Applications -- RCRA Part B Permit Applications for five mixed waste treatment facilities were submitted to the State of Idaho and a response to the first technical Notice of Deficiency is being prepared. Interim status was requested for another treatment facility and several amendments to RCRA Part A Permit Applications have been submitted and are awaiting response from the State of Idaho. In addition, RCRA closure plans were submitted for two other treatment facilities in August of 1993. 


\section{MIXED WASTE DISPOSAL ACTIVITIES FOR FY 1993}

The Idaho National Engineering Laboratory does not have any mixed waste disposal facilities. 


\section{ILLINOIS}


This page intentionally left blank. 


\section{ARGONNE NATIONAL LABORATORY-EAST \\ Argonne, Illinois}

Mission: The Argonne National Laboratory-East (ANL-E) is a multi-disciplinary research and development laboratory that conducts basic and applied research on the development of energy technologies and in the physical, life, and environmental sciences. Activities at the ANL-E include nuclear reactor design, synchrotion radiation accelerator design, and environmental research programs.

\section{RCRA COMPLIANCE AGREEMENTS OR ORDERS RELATING TO MIXED WASTE}

The ANL-E currently does not have any RCRA Compliance Agreements or Orders that relate to mixed waste.

\section{MIXED WASTE CHARACTERIZATION ACTIVITIES FOR FY 1993}

There were no activities conducted during FY 1993 to correct any past formal notifications of RCRA violations of waste characterization activities.

\section{MIXED WASTE STORAGE ACTIVITIES}

The ANL-E has six storage areas that store mixed low-level waste. One of these facilities also stores mixed transuranic waste. These facilities have the capacity to store $111 \mathrm{~m}^{3}$ of waste and are currently operated under interim status.

Internal Inspections -- The mixed waste storage facilities are inspected weekly by Waste Management Operations personnel. Any noncompliances identified during these inspections results in corrective action and notification is followed per established procedure. No significant compliance problems were identified during FY 1993 at the mixed waste storage facility.

External Inspections -- The State of Illinois EPA conducted an annual inspection of the mixed waste storage facility in January 1993. The EPA and Illinois EPA conducted a multimedia inspection in June 1993. No violations were alleged.

Facility Upgrades or Modifications -- No upgrades or modifications to the mixed waste storage facilities were conducted during FY 1993.

Permit Modifications or Applications -- No RCRA permit modifications or applications relating to mixed waste were submitted during FY 1993.

\section{MIXED WASTE TREATMENT ACTIVITIES}

The ANL-E has one mixed waste treatment facility that treats low-level waste. This facility is currently on standby status and no mixed waste was treated during FY 1993. 
Internal Inspections -- The mixed waste treatment facility is inspected weekly by Reactor Engineering personnel and a performance operation is conducted quarterly. No significant compliance problems were identified during FY 1993 at the mixed waste treatment facility.

External Inspections -- The State of Illinois EPA conducted an annual inspection of the mixed waste treatment facility in January 1993. The EPA and the State of Illinois EPA conducted a multimedia inspection in June 1993. No violations were alleged.

Facility Upgrades or Modifications -- No upgrades or modifications to the mixed waste treatment facility were conducted during FY 1993.

Permit Modifications or Applications -- A response to the Part B Permit Application Notice of Deficiency regarding the alkali metal reaction booth was submitted to the EPA in August 1993. The response was reviewed by the EPA and the agency has no further comments.

MIXED WASTE DISPOSAL ACTIVITIES

The ANL-E does not have any mixed waste disposal facilities. 


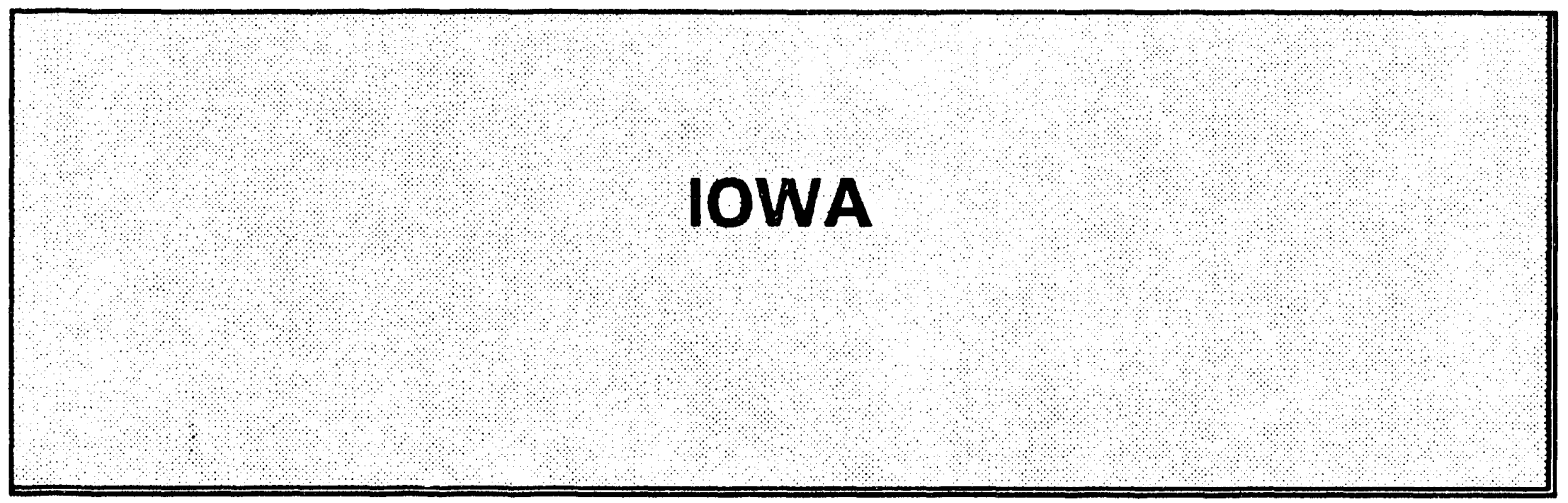


This page intentionally left blank. 


\section{AMES LABORATORY}

Ames, lowa

Mission: The Ames Laboratory conducts basic research in materials and chemicals sciences as well as related research in materials reliability and non-destructive evaluation. The primary missions of the Ames Laboratory are to 1) conduct pure and applied research in physical, mathematical, and engineering sciences that underlie eneroy technologies, 2) solve complex materials problems in energy production and use, 3) train new scientists and engineers, and 4/ conduct technology transfer.

\section{RCRA COMPLIANCE AGREEMENTS OR ORDERS RELATING TO MIXED WASTE}

The Ames Laboratory currently does not have any RCRA Compliance Agreements or Orders that relate to mixed waste.

\section{MIXED WASTE CHARACTERIZATION ACTIVITIES FOR FY 1993}

There were no activities conducted during FY 1993 to correct any past formal notifications of RCRA violations of waste characterization activities.

\section{MIXED WASTE STORAGE ACTIVITIES}

The Ames Laboratory has two satellite accumulation areas that store mixed low-level waste.

Internal Inspections -- The mixed waste accumulation areas are inspected weekly by a Chemical Safety Technician. Any noncompliances identified during these inspections are reported to the Chemical Safety Specialist. No significant compliance problems were identified during FY 1993.

External Inspections -- No inspections were conducted by the EPA or the State of lowa during FY 1993.

Facility Upgrades or Modifications -- No upgrades or modifications to the mixed waste storage facilities were conducted during FY 1993.

Permit Modifications or Applications -- No RCRA permit modifications or applications relating to mixed waste were submitted during FY 1993.

\section{MIXED WASTE TREATMENT ACTIVITIES}

The Ames Laboratory does not have any mixed waste treatment facilities.

\section{MIXED WASTE DISPOSAL ACTIVITIES}

The Ames Laboratory does not have any mixed waste disposal facilities. 
This page intentionally left blank. 


\section{KENTUCKY}


This page intentionally left blank. 


\section{PADUCAH GASEOUS DIFFUSION PLANT \\ Paducah, Kentucky}

Mission: The Paducah Gaseous Diffusion Plant began operations in 1952 to enrich uranium for national defense and commerclal reactors. The Paducah Gaseous Diffusion Ptant uses gaseous diffusion technology to enrich uranium. In July 1993, the United States Enrichment Corporation, through Congressional legislation, became responsible for uranium enrichment operation at the Paducah Gaseous Diffusion Plant. The DOE remains responsible for restoration and waste management programs at the Paducah Gaseous Diffusion Plant.

\section{RCRA COMPLIANCE AGREEMENTS OR ORDERS RELATING TO MIXED WASTE}

The Paducah Gaseous Diffusion Plant has three agreements or orders relating to the management of mixed waste that were effective during FY 1993. These include the following:

- Administrative Order by Consent

- Effective date November 23, 1988

- Negotiated between the DOE and the EPA Region IV

- Toxicity Characteristic Leaching Procedure Federal Facility Compliance Agreement

- $\quad$ Effective date March 4, 1992

- Negotiated between the DOE and the EPA Region IV

- $\quad$ Land Disposal Restrictions Federal Facility Compliance Agreement

- $\quad$ Effective date June 30, 1992
Negotiated between the DOE and the EPA Region IV

Five deliverables required by the Land Disposal Restrictions Federal Compliance Agreement were completed and submitted during FY 1993.

\section{MIXED WASTE CHARACTERIZATION ACTIVITIES FOR FY 1993}

The Paducah Gaseous Diffusion Plant has obtained a contractor to develop characterization plans for wastes covered by the Toxicity Characteristic Leaching Procedure Federal Facility Compliance Agreement in accordance with the implementation plan issued in April 1992.

\section{MIXED WASTE STORAGE ACTIVITIES FOR FY 1993}

The Paducah Gaseous Diffusion Plant has four mixed waste storage facilities that are permitted. Three of these facilities only store mixed low-level waste and the other facility stores both mixed low-level and mixed transuranic waste. These facilities have the capacity to store $3598 \mathrm{~m}^{3}$ of waste.

Internal Inspections -- The mixed waste storage facilities are inspected daily and/or weekly by trained Waste Management Department personnel as required by the RCRA Part B permit. Any noncompliances identified during these inspections are reported and corrected as required by the unusual occurrence reporting procedures. No significant compliance problems were identified at the mixed waste storage facilities during FY 1993. 
External Inspections -- The Kentucky Division of Waste Management conducted an annual RCRA inspection during September 24 through 29, 1993. The results from this inspection were positive overall. However, the Kentucky Division of Waste Management noted that formalized surveillance and inspection of safety equipment in RCRA areas is required.

Facility Uparades or Modifications -- No upgrades or modifications to the mixed waste storage facilities were conducted during FY 1993.

Permit Modifications or Applications -- The Paducah Gaseous Diffusion Plant added the United States Enrichment Corporation to it's RCRA and Hazardous and Solid Waste Amendments permits in June 1993.

\section{MIXED WASTE TREATMENT ACTIVITIES FOR FY 1993}

The Paducah Gaseous Diffusion Plant has three mixed waste treatment facilities that treated mixed low-level waste. All three of these facilities are on standby awaiting closure.

Internal Inspections -- The mixed waste treatment facilities are inspected daily and/or weekly by trained personnel in accordance with the RCRA Part B permit. No significant compliance problems were identified at the mixed waste treatment facilities during FY 1993.

External Inspections -- The Kentucky Division of Waste Management conducted a routine RCRA inspection of the mixed waste treatment facilities during September 24 through 29, 1993. The results from this inspection were positive overall. However, the Kentucky Division of Waste Management noted that formalized surveillance and inspection of safety equipment in RCRA areas is required.

Facility Upgrades or Modifications -- No upgrades or modifications to the mixed waste treatment facilities were conducted during FY 1993.

Permit Modifications or Applications -- Permit modifications to close the three existing mixed waste treatment facilities are underway. However, none were submitted during FY 1993.

\section{MIXED WASTE DISPOSAL ACTIVITIES FOR FY 1993}

The Paducah Gaseous Diffusion Plant does not have any mixed waste disposal facilities. 


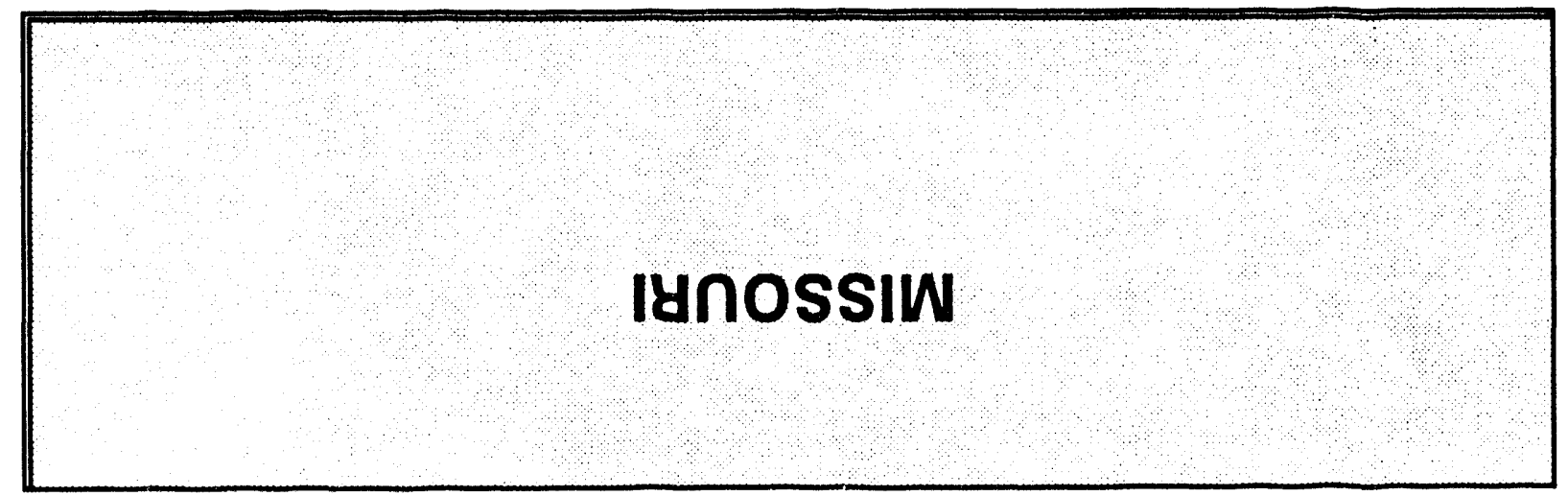


This page intentionally left blank. 


\section{KANSAS CITY PLANT \\ Kansas City, Missouri}

Mission: The Kansas City Plant produces and procures electrical, electronic, electromechanical, mechanical, olastic, and nonfissionable metal components for nuclear weapons. Operations began in 1949, however, prior to its current use, the facility was used as an airplane engine production plant for the U.S. Department of Defense.

\section{RCRA COMPLIANCE AGREEMENTS OR ORDERS RELATING TO MIXED WASTE}

The Kansas City Plant currently does not have any RCRA Compliance Agreements or Orders that relate to mixed waste.

\section{MIXED WASTE CHARACTERIZATION ACTIVITIES FOR FY 1993}

There were no activities conducted during FY 1993 to correct any past formal notifications of RCRA violations of waste characterization activities.

\section{MIXED WASTE STORAGE ACTIVITIES}

The Kansas City Plant has one waste storage facility that stores mixed low-level waste. This facility has the capacity to store 9655 -gallon drums $\left(20.4 \mathrm{~m}^{3}\right)$ of waste and is currently operated under interim status.

Internal Inspections -- The mixed waste storage facility is inspected weekly by Waste Management personnel according to written procedures contained in the plant's waste management plan. Any noncompliances identified during these inspections are reported to the Allied Signal, Waste Management and the Kansas City Area Office. No significant compliance problems were identified during FY 1993 at the mixed waste storage facility.

External Inspections -- No inspections were conducted by the EPA or the State of Missouri during FY 1993.

Facility Upgrades or Modifications -- No upgrades or modifications to the mixed waste storage facility were conducted during FY 1993.

Permit Modifications or Applications -- When the State of Missouri was granted RCRA mixed waste authority in March 1993, the State of Missouri requested the Kansas City Plant to resubmit a RCRA Part A Application. The application was submitted on April 2, 1993 and included information addressing mixed waste.

\section{MIXED WASTE TREATMENT ACTIVITIES}

The Kansas City Plant does not have any mixed waste treatment facilities.

\section{MIXED WASTE DISPOSAL ACTIVITIES}

The Kansas City Plant does not have any mixed waste disposal facilities. 


\section{UNIVERSITY OF MISSOURI RESEARCH REACTOR Columbia, Missouri}

Mission: The University of Missouri conducts experiments to separate radioactive actinide elements from spent fuel for the DOE. At the completion of testing, the DOE plans to decontaminate the facility to its original condition.

\section{RCRA COMPLIANCE AGREEMENTS OR ORDERS RELATING TO MIXED WASTE}

The University of Missouri currently does not have any RCRA Compliance Agreements or Orders that relate to mixed waste.

\section{MIXED WASTE CHARACTERIZATION ACTIVITIES FOR FY 1993}

There were no activities conducted during FY 1993 to correct any past formal notifications of RCRA violations of waste characterization activities.

\section{MIXED WASTE STORAGE ACTIVITIES}

The University of Missouri has one storage facility for mixed low-level and mixed transuranic waste. This facility has the capacity to store 1655 -gallon drums of mixed waste and is currently operated as a permitted facility.

Internal Inspections -- The University of Missouri does not have an internal inspection program.

External Inspections -- No inspections were conducted by the EPA or the State of Missouri during FY 1993.

Facility Upgrades or Modifications - No upgrades or modifications to the mixed waste storage facility were conducted during FY 1993.

Permit Modifications or Applications -- No RCRA permit modifications or applications relating to mixed waste were submitted during FY 1993.

\section{MIXED WASTE TREATMENT ACTIVITIES}

The University of Missouri does not have any mixed waste treatment facilities.

\section{MIXED WASTE DISPOSAL ACTIVITIES}

The University of Missouri does not have any mixed waste disposal facilities. 


\title{
WELDON SPRING SITE REMEDIAL ACTION PROJECT
}

\author{
St. Charles County, Missouri
}

Mission: The Weldon Spring Site Remedial Action Project was developed by the U.S. Army for explosives production during World War $\|$ and was operated by the Atomic Energy Commission from 1955 to 1966 as a uranium processing plant.

\section{RCRA COMPLIANCE AGREEMENTS OR ORDERS RELATING TO MIXED WASTE}

The Weldon Spring Site Remedial Action Project currently does not have any RCRA Compliance Agreements or Orders that relate to mixed waste.

\section{MIXED WASTE CHARACTERIZATION ACTIVITIES FOR FY 1993}

There were no activities conducted during FY 1993 to correct any past formal notifications of RCRA violations of waste characterization activities.

\section{MIXED WASTE STORAGE ACTIVITIES}

The Weldon Spring Site Remedial Action Project has three waste storage facilities that store mixed lowlevel waste. These facilities have the capacity to siore over $109,727 \mathrm{~m}^{3}$ of mixed waste. The Weldon Spring Site Remedial Action Project is a CERCLA site, and therefore, exempt from obtaining a permit. These three storage facilities meet the substantive requirements of RCRA.

Internal Inspections -- The mixed waste storage facilities are inspected weekly by the Regulatory Compliance Group and the inspections are documented on storage facility-specific checklists. Any noncompliances identified during these inspections are documented and the corrective actions are tracked. No significant compliance problems were identified during FY 1993 at the mixed waste storage facility.

External Inspections -- The Missouri Department of Natural Resources conducted a routine inspection on June 2-3, 1993. No violations were alleged.

Facility Upgiades or Modifications -- The Weldon Spring Site Remedial Action Project initiated floor repair at one of the mixed waste storage facilities during FY 1993 in response to a letter of warning dated August 13, 1993 from the Missouri Department of Natural Resources.

Permit Modifications or Applications -- The Weldon Spring Site Remedial Action Project is a CERCLA site, and is therefore exempt from obtaining a permit.

\section{MIXED WASTE TREATMENT ACTIVITIES}

The Weldon Spring Site Remedial Action Project has one mobile waste treatment facility that treats mixed low-level waste.

Internal Inspections -- The mixed waste treatment facility is inspected weekly by the Regulatory Compliance Group and the inspections are documented on treatment facility-specific checklists. Any noncompliances identified during these inspections are documented and the corrective actions are 
tracked. No significant compliance problems were identified during FY 1993 at the mixed waste treatment facility.

External Inspections -- The Missouri Department of Natural Resources conducted a routine inspection on June 2-3, 1993. No violations were alleged.

Facility Upgrades or Modifications -- No upgrades or modifications to the mixed waste treatment facility were conducted during FY 1993.

Permit Modifications or Applications -- The Weldon Spring Site Remedial Action Project is a CERCLA site, and is therefore exempt from obtaining a permit. A Record of Decision was signed in September, 1993 that authorizes a new treatment facility to treat mixed waste on site.

\section{MIXED WASTE DISPOSAL ACTIVITIES}

The Weldon Spring Site Remedial Action Project does not have any mixed waste disposal facilities. 


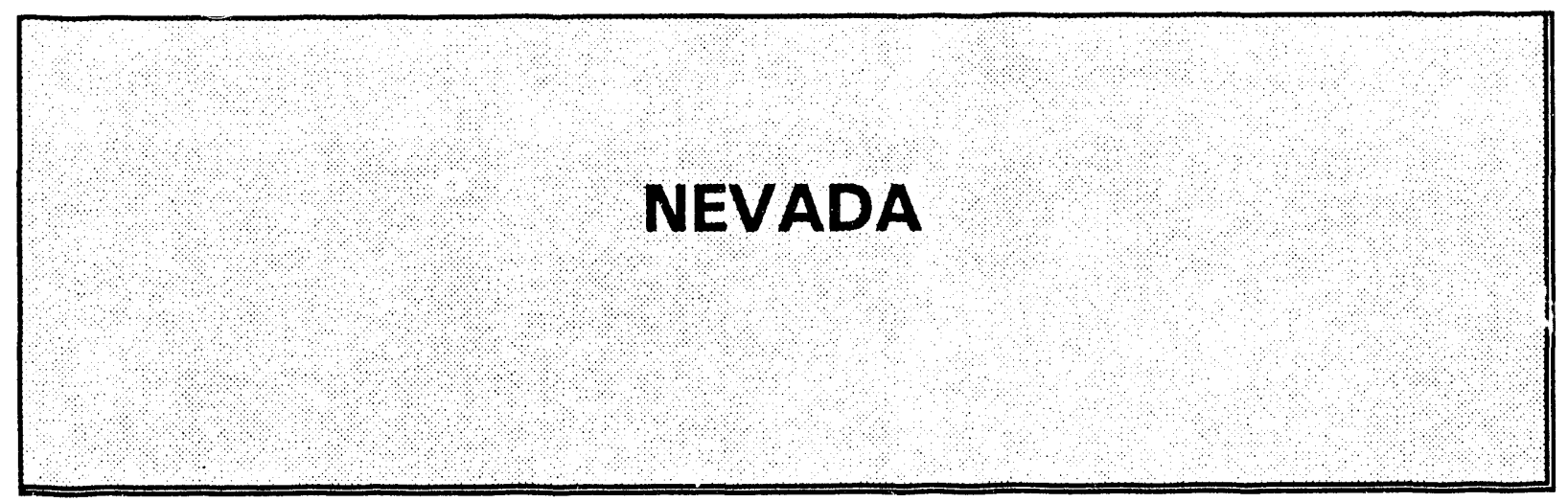


This page intentionally left blank. 


\section{NEVADA TEST SITE Mercury, Nevada}

Mission: The Nevada Test Site (NTS) was established in the early 1950 s to serve as a proving oround for the testing and development of nuclear weapons.

\section{RCRA COMPLIANCE AGREEMENTS OR ORDERS RELATING TO MIXED WASTE}

The NTS has one agreement dealing with storage of mixed waste that was effective during FY 1993. This agreement is the Settlement Agreement for Storage of Mixed Transuranic Waste that was signed June 23, 1992. The NTS is also negotiating a consent agreement for storage of mixed low-level waste to be generated at the NTS.

\section{MIXED WASTE CHARACTERIZATION ACTIVITIES FOR FY 1993}

No violations for mixed waste characterization activities were received during FY 1993. However, the NTS continues to work with the Nevada Division of Environmental Protection to resolve current issues and concerns related to waste characterization. These issues were a result of ongoing state review as a part of the NTS Agreement in Principle, and as a review of the NTS RCRA Part B Permit Application.

\section{MIXED WASTE STORAGE ACTIVITIES FOR FY 1993}

The NTS has one mixed waste storage facility that stores mixed transuranic waste. This facility has the capacity to store $612 \mathrm{~m}^{3}(161,691$ gallons) of waste and is operated under provisions of the June 1992 Settlement Agreement. The storage facility does not require special accommodations but some institutional controls such as special radioiogical monitoring and access control are provided for the transuranic waste.

Internal Inspections -- The mixed waste storage facility is inspected weekly and monthly by the operating contractor. Any noncompliances identified during these inspections are reported to the Facility Manager who in turn notifies the DOE Nevada Operations Office Waste Management Division. If noncompliances can not be corrected immediately and would require long term corrective action, the DOE Nevada Operations Office notifies the State of Nevada Department of Environmental Protection. No significant compliance problems were identified during FY 1993 at the mixed waste storage facility.

External Inspections -- The EPA Region IX conducted a routine compliance inspection in July 1992. The State of Nevada Department of Environmental Protection conducts compliance inspections frequently and they are usually unannounced. No violations were alleged regarding the mixed waste storage facility.

Facility Upgrades or Modifications -- The mixed waste storage facility is being upgraded to include a cover which will provide protection from wind and weather. This is in response to requirements outlined in the Settlement Agreement and is not the result of any alleged violation.

Permit Modifications or Applications -- The NTS RCRA Part B Permit Application was submitted July 1992 and included the mixed waste storage facility. Because the unit is operating under provisions of the Settlement Agreement, the State of Nevada indicated that this unit will probably not receive a RCRA permit. 


\section{MIXED WASTE TREATMENT ACTIVITIES FOR FY 1993}

The NTS does not have any mixed waste treatment facilities.

\section{MIXED WASTE DISPOSAL ACTIVITIES FOR FY 1993}

The NTS has one mixed low-level waste disposal pit. The mixed waste disposal pit is an existing unit that has not received any mixed waste since May 1990.

Internal Inspections -- The mixed low-level waste disposal pit is inspect:d weekly and monthly by the operating contractor. Any noncompliances identified during these inspections are reported to the Facility Manager who in turn notifies the DOE Nevada Operations Office Waste Management Division. If noncompliances can not be corrected immediately and would require long term corrective action, the DOE Nevada Operations Office notifies the State of Nevada Department of Environmental Protection. No significant compliance problems were identified during FY 1993 at the mixed waste storage facility.

External Inspections -- The EPA Region IX conducted a routine compliance inspection in July 1992. The State of Nevada Department of Environmental Protection conducts compliance inspections frequently and they $i e$ usually unannounced. No violations were alleged regarding the mixed waste disposal pit.

In 1991 the NTS was cited for alleged waste analysis deficiencies related to pondcrete from the Rocky Flats Plant which is disposed in the mixed waste disposal pit. The NTS management and operating contractor and the Nevada Department of Environmental Protection resolved the issue through a consent decree. Under the provisions of this consent decree, additional sampling and analysis of the Rocky Flats Plant Pondcrete is being conducted.

Facility Upgrades or Modifications -- The mixed waste disposal pit was upgraded by improving drainage and the waste containers previously placed in the pit were covered with soil.

Permit Modifications or Applications -- The NTS RCRA Part B Permit Application was submitted in July 1992. A notice of deficiency was received in November 1992 and responded to in February 1993. Initial technical comments were received in July 1993 and revisions are being prepared. 


\section{NEW MEXICO}


This page intentionally left blank.

CHIEF FINANCIAL OFFICER'S REPORT-1993

A-62 


\section{INHALATION TOXICOLOGY RESEARCH INSTITUTE}

Albuquerque, Now Mexico

Mission: The mission of the Inhalation Toxicology Research Institute (ITRI) is to improve the scientific basis for understanding the impact on human health of inhaled materials that are toxic by virtue of their radiological, chemical, or physical nature.

\section{RCRA COMPLIANCE AGREEMENTS OR ORDERS RELATING TO MIXED WASTE}

The ITRI currently does not have any RCRA Compliance Agreements or Orders that relate to mixed waste.

\section{MIXED WASTE CHARACTERIZATION ACTIVITIES FOR FY 1993}

There were no activities conducted during FY 1993 to correct any past formal notifications of RCRA violations of waste characterization activities.

\section{MIXED WASTE STORAGE ACTIVITIES FOR FY 1993}

The ITRI has one waste storage facility that a portion of which is used to store mixed low-level waste. This facility has the capacity to store nine 55-gallon drums of mixed waste and is currently operated under interim status.

Internal Inspections -- The mixed waste storage facility is inspected weekly. A log book is maintained and each inspection is logged in the book. Any noncompliances are reported to the Kirtland Area Office who notifies the New Mexico Environment Department. No significant compliance problems were identified during FY 1993 at the mixed waste storage facility.

It was identified during an internal audit performed by the Waste Management staff in 1992 that the ITRI's storage of drums containing mixed waste exceeded the 270-day storage limit for small quantity generators. The ITRI is negotiating with Sandia National Laboratories/New Mexico to store the drums at that site.

External Inspections -- The EPA Region VI conducted a routine inspection of the mixed waste storage facility on September 9, 1993. No violations were alleged.

Facility Upgrades or Modifications -- No upgrades or modifications to the mixed waste storage facility were conducted during FY 1993.

Permit Modifications or Applications -- No RCRA permit modifications or applications relating to mixed waste were submitted during FY 1993.

\section{MIXED WASTE TREATMENT ACTIVITIES FOR FY 1993}

The ITRI does not have any mixed waste treatment facilities.

\section{MIXED WASTE DISPOSAL ACTIVITIES FOR FY 1993}

The ITRI does not have any mixed waste disposal facilities. 


\section{LOS ALAMOS NATIONAL LABORATORY \\ Los Alamos, Now Mexico}

Mission: The Los Alamos National Laboratory (LANL) was originally established in 1943 by the U.S. Army's Manhattan Engineer District for the purpose of developing the first atomic bombs. The primary mission is nuclear weapons research end development. In addition, many programs are conducted at LANL in the nuclear, environmental, and energy sciences; fusion; laser isotope separation; and basic research in the areas of physics, chemistry, radiolooy, and medicine.

\section{RCRA COMPLIANCE AGREEMENTS OR ORDERS RELATING TO MIXED WASTE}

The LANL and the LOS Alam.s Area Office have negotiated and submitted a Federal Facilities Compliance Agreement on Land Disposal Restrictions requirements with the EPA Region VI. This Agreement is currently in the public comment period and is expected to be signed and effective by the end of the Calendar Year 1993. The LANL completed during FY 1993 eight deliverables required by the RCRA Federal Facility Compliance Agreement.

\section{MIXED WASTE CHARACTERIZATION ACTIVITIES FOR FY 1993}

There were no activities conducted during FY 1993 to correct any past formal notifications of RCRA violations of waste characterization activities.

\section{MIXED WASTE STORAGE ACTIVITIES FOR FY 1993}

The LANL has eleven mixed waste storage facilities that are currently operated under interim status. Mixed transuranic waste is stored at three of these facilities and mixed low-level waste is stored at most of the facilities. The total design capacity for these facilities is over $13,370,000$ gallons of mixed waste. One of these facilities requires lead shielding of the waste due to the high exposure rates and at another facility the waste is stored in shielded shafts.

Internal Inspections -- The mixed waste storage facilities are inspected daily and weekly by the assigned personnel from the operating group that manages the mixed waste unit. In addition to unitspecific regulatory inspection requirements, the LANL has incorporated additional requirements for inspection of safety and emergency equipment, monitoring equipment, security derices, and operating and structural equipment in the inspection schedules. One of the additional reijuirements includes radiation screening during inspection at the mixed waste units so that exposure to personnel is as low as reasonably achievable. If any defects, deterioration, damage, or potential hazards are discovered during an inspection, appropriate action, which may include repa irs, maintenance, and replacement, are completed promptly to minimize further damage and prevent the need for emergency repairs. Any preventative action taken in response to an inspection is noted on the Inspection Record Form. A copy of the inspection records are sent to the Environmental Protection Group, Hazardous and Solid Waste Section at the end of each work week. The inspection records are available for review by the New Mexico Environment Department and the EPA.

During one of the inspections conducted in FY 1993, it was noted that the dates on the drum labels at one of the storage facilities could not be verified. In order to correct this problem, the drums have now been barcoded. 
External Inspections -- The EPA Region VI performed a multimedia inspection during August 2-12, 1993. The New Mexico Environment Department performed an annual RCRA inspection at the same time. Results of these inspections have not been released to date.

During FY 1993 an updated manifest tracking system which includes occurrence notification to the State of New Mexico was implemented. Deficiencies in the old system were identified during the New Mexico Environment Department and the EPA 1992 multimedia audit.

Facility Uparades or Modifications -- The transuranic waste storage pad remediation design and temporary transuranic storage domes design have been completed. These remediation and storage facilities are corrective actions for the New Mexico Environment Department Compliance Order issued from the results of an inspection performed in May, 1992.

Permit Modifications or Applications -- The LANL submitted a RCRA Part B Permit Application to the New Mexico Environmental Department for one of the storage facilities on September 30, 1993.

\section{MIXED WASTE TREATMENT ACTIVITIES FOR FY 1993}

The LANL has two mixed waste detonation sites, two cementation processes, and one oxygen sparging furnace. All of these facilities are currently operated under interim status. The LANL also has one controlled air incinerator which is currently not operating and is awaiting upgrades and permit modification. This facility will be used to treat both mixed transuranic and mixed low-level waste.

Internal Inspections -- The mixed waste treatment facilities are inspected by the assigned personnel from the operating group that manages the mixed waste unit. The controlled air incinerator is inspected hourly and daily when operating and weekly whether operating or not. The other treatment facilities are inspected both daily when operating and weekly whether operating or not. If any defects, deterioration, damage, or potential hazards are discovered during an inspection of the treatment facilities, appropriate action, which may include repairs, maintenance, and replacement, are completed promptly to minimize further damage and prevent the need for emergency repairs. If an imminent hazard or existing hazard is noted during an inspection of the incinerator, it is shut down and emergency action is initiated immediately. The incinerator is not reused until remedial action is complete. Any action taken in response to an inspection is noted on the Inspection Record Form. A copy of the inspection records are sent to the Environmental Protection Group, Hazardous and Solid Waste Section at the end of each work week. The inspection records are available for review by the New Mexico Environment Department and the EPA. No significant compliance problems were identified during FY 1993 at the mixed waste treatment facility.

External Inspections -- The EPA Region VI performed a multimedia inspection during August 2-12, 1993. The New Mexico Environment Department performed an annual RCRA inspection at the same time. Results of these inspections have not been released to date.

Facility Uparades or Modifications -- During FY 1993 the Title I Design upgrades to the controlled air incinerator were completed and upgrades on the lead decontamination trailer designs were completed.

Permit Modifications or Applications -- A request for RCRA Part B permit modifications were submitted to the New Mexico Environmental Department for three hazardous waste treatment facilities in FY 1993.

\section{MIXED WASTE DISPOSAL ACTIVITIES FOR FY 1993}

The LANL does not have any mixed waste disposal facilities. 


\section{SANDIA NATIONAL LABORATORIESINEW MEXICO \\ Albuquerque, New Mexico}

Mission: Established in 1949, the primary function of Sandia National Laboratories/New Mexico (SNL/NM) is the research and development of weapons which use nuclear explosives. This includes the design of the armino, fusing, and frino systems used in nuclear bombs and warheads, Other projects include nuclear reactor safoty studies; development of safe transport and storape systems for special nuclear material including plutonium and uranium; radioactive waste disposal techniques and site studies; pulsed power research; vertical axis wind turbine research; and fossil fuel and peothermal energy research.

\section{RCRA COMPLIANCE AGREEMENTS OR ORDERS RELATING TO MIXED WASTE}

The SNL/NM currently does not have any RCRA Compliance Agreements or Orders that relate to mixed waste.

\section{MIXED WASTE CHARACTERIZATION ACTIVITIES FOR FY 1993}

There were no activities conducted during FY 1993 to correct any past formal notifications of RCRA violations of waste characterization activities.

\section{MIXED WASTE STORAGE ACTIVITIES FOR FY 1993}

The SNL/NM has five mixed waste storage facilities that are currently operated under interim status. These facilities have the capacity to store a total of $4825 \mathrm{~m}^{3}$ of mixed low-level waste and one facility also has the capacity to store two 55-gallon drums of mixed transuranic waste.

Internal Inspections -- The mixec

Any noncompliances identified 0 Kirtla Area Office then notifies ،. comiriance problems were identified orage facilities are inspected weekly by the facility owners. se inspections are reported to the Kirtland Area Office. The date of New Mexico Environment Department. No significant during FY 1993 at the mixed waste storage facilities.

External Inspections -- The EPA Region VI conducted a routine inspection of the mixed waste storage facilities on September 30, 1993 and the New Mexico Environment Department conducted a routine inspecion of the mixed waste storage facilities during July 19-23, 1993. The New Mexico Environment Department identified violations relating to mixed waste storage.

A 1992 audit by the New Mexico Environment Department identified as a violation faded labels and illagible markings on drums. The corrective action taken was to place the drums into transport containers to alleviate the outdoor weathering effects to the labels and the labels were replaced.

Facility Uparades or Modifications -- Mixed low-level waste drums that were previously stored outside were moved inside transport containers.

Permit Modifications or Applications -- The SNL/NM submitted a RCRA Part B Permit Application in November 1992. An amendment to the application was submitted in August 1993. A second amendment will be submitted in D. cember 1994. 


\section{MIXED WASTE TREATMENT ACTIVITIES FOR FY 1993}

The SNL/NM has one mixed waste treatment facility that is currently under construction and one mixed waste treatment facility that the initial design has begun. Both facilities are intended to treat mixed low-level waste. These facilities have been included in the August 1993 RCRA Part B permit amendment.

\section{MIXED WASTE DISPOSAL ACTIVITIES FOR FY 1993}

The SNL/NM does not have any mixed waste disposal facilities. 
This page intentionally left blank. 


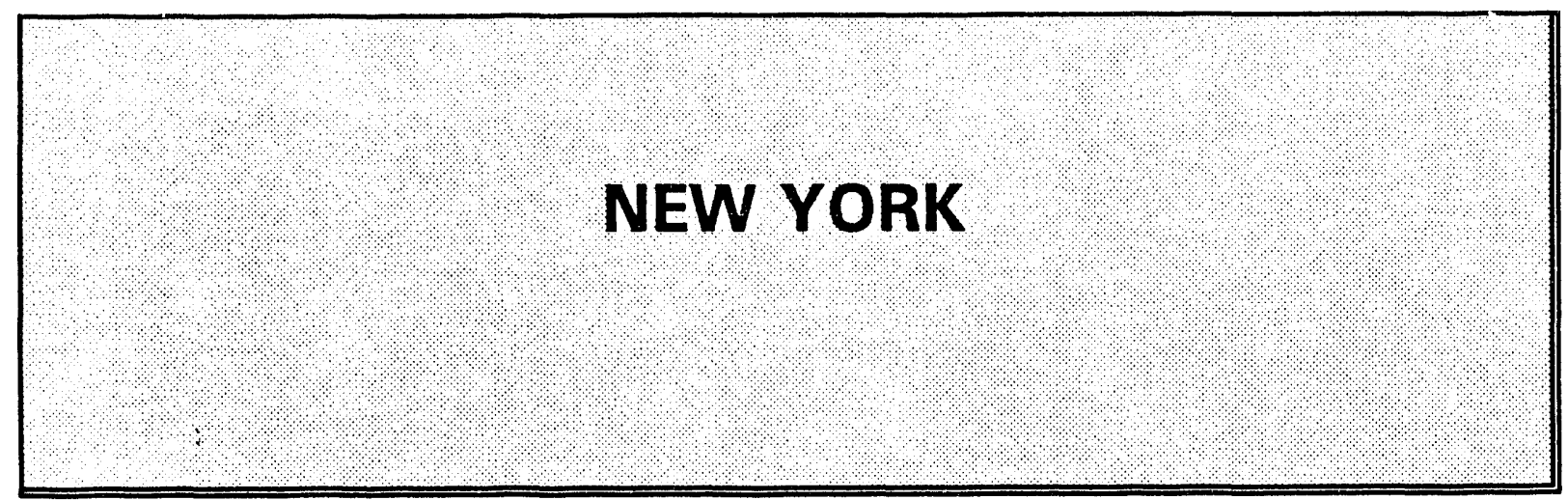


This page intentionally left blank. 


\section{BROOKHAVEN NATIONAL LABORATORY Upton, New York}

Mission: Historically, the site was used by the U.S. Army as a post (called Camp Upton) during the First and Second World Wars. The Atomic Eneroy Commission was given title to the property in 1947 and subsequently transferred it to the Energy Research and Development Administration in 1975, which became the U.S. Department of Eneroy in 1977.

The Brookhaven National Laboratory (BNL) functions as a desion, construction, and operations center for large research tacilities such as particle accelerators, nuclear reactors and synchrotron storage rings for research in high-energy and nuclear physics, chemistry, biology and energy-related life and environmental sciences.

\section{RCRA COMPLIANCE AGREEMENTS OR ORDERS RELATING TO MIXED WASTE}

The BNL is currently negotiating a draft RCRA Compliance Agreement/Consent Order with the EPA which includes a requirement for the BNL to amend its RCRA Closure Plan to include mixed waste. This resulted from a June, 1992 inspection by the New York State Department of Environmental Conservation which included a finding that the BNL's Closure Plan did not address mixed waste.

\section{MIXED WASTE CHARACTERIZATION ACTIVITIES FOR FY 1993}

There were no activities conducted during FY 1993 to correct any past formal notifications of RCRA violations of waste characterization activities.

\section{MIXED WASTE STORAGE ACTIVITIES}

The BNL has five storage areas that store mixed low-level waste. These facilities have the capacity to store over $110 \mathrm{~m}^{3}$ of waste and are currently operated under a RCRA Part B permit. Ignitable mixed low-level waste is stored in a facility with a fire suppressing system.

Internal Inspections -- The mixed waste storage facilities are inspected weekly by Hazardous Waste Management Technicians during the Hazardous Waste Management Facility RCRA inspection. Any noncompliances identified during these inspections are tracked by the Hazardous Waste Management Quality Assurance group until closure of the corrective action. No significant compliance problems were identified during FY 1993 at the mixed waste storage facility.

External Inspections -- The New York State Department of Environmental Conservation conducted a routine annual RCRA inspection on June 22, 1993. A report from this inspection has not yet been received.

Facility Upgrades or Modifications -- The BNL installed at the mixed waste storage facility a new HAZTOR Module $\# 368$ to provide fire protection, heat, and secondary containment for mixed low-level waste.

Permit Modifications or Applications -- No RCRA permit modifications or applications relating to mixed waste were submitted during FY 1993. 
MIXED WASTE TREATMENT ACTIVITIES

The BNL does not have any mixed waste treatment facilities.

MIXED WASTE DISPOSAL ACTIVITIES

The BNL does not have any mixed waste disposal facilities. 


\section{COLONIE INTERIM STORAGE SITE \\ Colonie, New York}

Mission: The Colonie Interim Storage Site is part of DOE's Formerly Utilized Sites Remedial Action Program (FUSRAP) and Is currently used for the interim storage of wastes generated from past site operations. The site was privately owned and operated and produced uranium products under a license issued by the Atomic Energy Commission from 1958 through 1984. To date, 53 of the 56 designated vicinity properties have been remediated, Current FUSRAP activities include implementation of the epproved RCRA Closure Plan, disposal of esbestos materials, and decontamination of equipment and interior surfaces within the butlding.

\section{RCRA COMPLIANCE AGREEMENTS OR ORDERS RELATING TO MIXED WASTE}

The Colonie Interim Storage Site currently does not have any RCRA Compliance Agreements or Orders that relate to mixed waste.

\section{MIXED WASTE CHARACTERIZATION ACTIVITIES FOR FY 1993}

There were no activities conducted during FY 1993 to correct any past formal notifications of RCRA violations of waste characterization activities.

\section{MIXED WASTE STORAGE ACTIVITIES}

The Colonie Interim Storage Site has two storage facilities that store mixed low-level waste. These facilities have the total capacity to store approximately 5,060 gallons of waste and are currently operated under the RCRA Closure Plan.

Internal Inspections -- The mixed waste storage facility is inspected weekly by onsite Quality Assurance Coordinator and an Annual Environmental Compliance Audit is conducted by the Project Management Contractor's Corporate Quality Assurance personnel. Any noncompliances identified during these inspections are reported to the FUSRAP Program Manager. No significant compliance problems were identified during FY 1993 at the mixed waste storage facilities.

External Inspections -- The Colonie Interim Storage Site submitted a resolution package on May 28, 1993 to respond to a Notice of Violation received on April 30, 1993 from the New York State Department of Environmental Conservation. The New York State Department of Environmental Conservation closed the Notice of Violation on June 14, 1993. In addition, the New York State Department of Environmental Conservation performed a routine annual hazardous waste compliance inspection on September 28, 1993. No violations were alleged.

Facility Upgrades or Modifications -- No upgrades or modifications to the mixed waste storage facilities were conducted during FY 1993.

Permit Modifications or Applications -- No RCRA permit modifications or applications relating to mixed waste were submitted during FY 1993. 
MIXED WASTE TREATMENT ACTIVITIES

The Colonie Interim Storage Site does not have any mixed waste treatment facilities.

MIXED WASTE DISPOSAL ACTIVITIES

The Colonie Interim Storage Site does not have any mixed waste disposal facilities. 


\section{KNOLLS ATOMIC POWER LABORATORY KESSELRING SITE West Milton, New York}

Mission: The Knolls Atomic Power Laboratory-Kesselring IKAPL-Kesselringl is engaged solely in research and development for the design and operation of naval nuclear propulsion plants. Activities relating to naval nuclear propulsion systems aro performed in eccordance with the requirements and authority of the Naval Nuclear Propulsion Program. The Kesselring prototype site is also used to provide full-scale testing of propulsion plant hardware and to train personnel to operate these plants.

\section{RCRA COMPLIANCE AGREEMENTS OR ORDERS RELATING TO MIXED WASTE}

The KAPL-Kesselring currently does not have any RCRA Compliance Agreements or Orders that relate to mixed waste.

\section{MIXED WASTE CHARACTERIZATION ACTIVITIES FOR FY 1993}

There were no activities conducted during FY 1993 to correct any past formal notifications of RCRA violations of waste characterization activities.

\section{MIXED WASTE STORAGE ACTIVITIES}

The KAPL-Kesselring has one storage area that stores mixed low-level waste. This facility has the capacity to store $29 \mathrm{~m}^{3}$ of waste and is currently operated under interim status.

Internal Inspections -- The mixed waste storage facility is inspected weekly by a radioactive waste inspector. Any noncompliances identified during these inspections are reported to Environment, Safety And Health Manager. The Field Office is notified if a violation exists. No significant compliance problems were identified during FY 1993 at the mixed waste storage facility.

External Inspections -- The New York State Department of Environmental Conservation performed a routine annual inspection in August 1993. No violations were alleged.

Facility Upgrades or Modifications -- No upgrades or modifications to the mixed waste storage facility were conducted during FY 1993.

Permit Modifications or Applications -- The KAPL-Kesselring updated their RCRA Part B Permit Application for hazardous and mixed waste. This application is currently being reviewed by the State of New York.

\section{MIXED WASTE TREATMENT ACTIVITIES}

The KAPL-Kesselring does not have any mixed waste treatment facilities.

\section{MIXED WASTE DISPOSAL ACTIVITIES}

Ti. KAPL-Kesselring does not have any mixed waste disposal facilities.

CHIEF FINANCIAL OFFICER'S REPORT-1993 


\section{KNOLLS ATOMIC POWER LABORATORY SCHENECTADY \\ Niskayuna, Now York}

Mission: The Knolls Atomic Power Laboratory-Knolls (KAPL-Knolls) is engaged solely in research and development for the desion and operation of naval nuclear propulsion plants. Activities relating to neval nuclear propulsion systems are performed in accordance with the requirements and authority of the Naval Nuclear Propulsion Program. Facilities at the site include machine shops, waste-handling facilities, a boller house, and chemistry, physics, and metallurgy laboratories.

\section{RCRA COMPLIANCE AGREEMENTS OR ORDERS RELATING TO MIXED WASTE}

The KAPL-Knolls does not have any RCRA Compliance Agreements or Orders that relate to mixed waste.

\section{MIXED WASTE CHARACTERIZATION ACTIVITIES FOR FY 1993}

There were no activities conducted during FY 1993 to correct any past formal notifications of RCRA violations of waste characterization activities.

\section{MIXED WASTE STORAGE ACTIVITIES}

The KAPL-Knolls has two waste storage facilities that store mixed waste and are currently operated under interim status. One of these storage facilities only stores mixed low-level waste and has the capacity to store $5 \mathrm{~m}^{3}$ of waste. The other storage facility can store mixed low-level and mixed transuranic waste. This second facility has the capacity to store 3,520 gallons of waste but is currently empty.

Internal Inspections -- The mixed waste storage facilities are inspected weekly by the Area Supervisor and quarterly inspections are conducted by the Oversite Engineering Group. Any noncompliances identified during these inspections are reported to the local Field Office for further action, as necessary. No significant compliance problems were identified during FY 1993 at the mixed waste storage facilities.

External Inspections -- The New York State Department of Environmental Conservation performed a routine annual inspection on August 27, 1993. No violations were alleged.

Facility Upgrades or Modifications -- No upgrades or modifications to the mixed waste storage facility were conducted during FY 1993.

Permit Modifications or Applications -- No RCRA permit modifications or applications relating to mixed waste were submitted during FY 1993.

\section{MIXED WASTE TREATMENT ACTIVITIES}

The KAPL-Knolls does not have any mixed waste treatment facilities. 


\section{MIXED WASTE DISPOSAL ACTIVITIES}

The KAPL-Knolls does not have any mixed waste disposal facilities. 


\section{WEST VALLEY DEMONSTRATION PROJECT West Valley, Now York}

Mission: The West Valley Demonstration Project (WVDP) is located on the site of the only commerclal nuclear fuel reprocessing plant to have operated in the United States. The reprocessing plant was operated commerclally from 1966 to 1972 under a lease from the New York State Energy Research and Development Authority. In accordance with the 1980 WVDP Act IP.L. 96. 3681, the WVDP mission has been to demonstrate high-level radioactive waste solidification techniques on a portion of the site without taking title to the waste. Both the site and the waste are owned by New York State.

\section{RCRA COMPLIANCE AGREEMENTS OR ORDERS RELATING TO MIXED WASTE}

The WVDP negotiated a Federal and State Facility Compliance Agreement that addresses RCRA compliance issues associated with mixed waste management. This agreement was fully executed in March of 19S3. In addition, in March of 1992, a RCRA 3008(h) Consent Order addressing RCRA corrective action requirements was fully executed. Both agreements were signed by the EPA Region II and the New York State Department of Environmental Conservation.

\section{MIXED WASTE CHARACTERIZATION ACTIVITIES FOR FY 1993}

The WVDP received a Notice of Noncompliance that addressed all issues covered in the Draft Federal and State Facility Compliance Agreement (including waste characterization/analysis issues) in September 1992. The Notice of Noncompliance was satisfied with the execution of the Federal and State Facility Compliance Agreement in March 1993. The Federal and State Facility Compliance Agreement requires the WVDP to submit a "historical report" of all available information to the EPA and the New York State Department of Environmental Conservation. This report was submitted in July 1993. Sampling and analysis may be requested by the regulators.

\section{MIXED WASTE STORAGE ACTIVITIES}

The WVDP has seven storage facilities that store mixed low-level waste. One of these facilities also stores transuranic wastes. These facilities have the capacity to store 4 million gallons of waste and are currently operated under interim status. The WVDP also operates several satellite accumulation areas for storage of mixed low-level waste. The mixed high-level waste is managed at the WVDP mixed waste treatment facility, which is discussed under Mixed Waste Treatment Activities.

The Federal and State Facility Compliance Agreement allows for alternative inspection practices for three of the mixed waste storage facilities. This will allow for dense packing mixed waste for shielding purposes and as low as reasonably achievable concerns, and the containers may be inspected by a visual overview of the storage array.

Internal Inspections -- West Valley Nuclear Services Co., Inc. Operations personnel perform weekly inspections which meet Federal and corresponding New York State Department of Environmental Conservation regulations. If a noncompliance is identified during these inspections, per onsite procedures, the Regulatory Compliance Manager is notified and appropriate actions are ta :en. No significant compliance problems were identified during FY 1993 at the mixed waste storage facilities. 
External Inspections -- The New York State Department of Environmental Conservation performed a routine annual hazardous waste inspection in March 1993. No violations were alleged. The WVDP received a Notice of Noncompliance in September 1992 that addressed all issues covered in the Draft Federal and State Facility Compliance Agreement. The Notice of Noncompliance was satisfied with the execution of the Federal and State Facility Compliance Agreement in March 1993. The Federal and State Facility Compliance Agreement requires WVDP to submit a "historical report" of all available information to the EPA and the New York State Department of Environmental Conservation. This report was submitted in July 1993. Sampling and analysis may be requested by the regulators.

Facility Uparades or Modifications -- No upgrades or modifications to the mixed waste storage facility were conducted during FY 1993.

Permit Modifications or Apolications -- A modification to the WVDP RCRA Part A Application was submitted to the New York State Department of Environmental Conservation in April 1993. No formal response has been received to date. However, only one change required their approval.

\section{MIXED WASTE TREATMENT ACTIVITIES}

The WVDP operated one high-level waste treatment facility in FY 1993. This facility is currently operated under interim status. Another facility for the treatment of high-level waste is under construction.

Internal Inspections -- Operations personnel from West Valley Nuclear Service Co., Inc. perform daily inspections which meet Federal and corresponding New York State Department of Environmental Conservation regulations. If a noncompliance is identified during these inspections, per onsite procedures, the Regulatory Compliance Manager is notified and appropriate actions are taken. No significant compliance problems were identified in FY 1993 at the mixed waste treatment facilities.

External Inspections -- The New York State Department of Environmental Conservation performed a routine annual hazardous waste inspection in March 1993. No violations were alleged.

Facility Upgrades or Modifications -- No upgrades or modifications to the mixed waste treatment facility were conducted during FY 1993.

Permit Modifications or Applications -- A modification to the WVDP RCRA Part A Apprication was submitted to the New York State Department of Environmental Conservation in April 1993. No formal response has been received to date. However, only one change required their approval.

\section{MIXED WASTE DISPOSAL ACTIVITIES}

The WVDP does not have any mixed waste disposal facilities. 
This page intentionally left blank. 


\section{OHIO}


This page intentionally left blank. 


\section{BATTELLE COLUMBUS LABORATORIES DECOMMISSIONING PROJECT \\ Columbus, Ohio}

Mission: Atomic energy research and development activities have been performed at Battelle Columbus Laboratories (BCL) for the DOE and its predecessor agencies since 1943 , Portions of 15 buildings and associated soil areas are radioactively contaminated as a result of previous work under government contract. These areas are expected to be decontaminated and released to BCL. for other use without radiological restrictions.

\section{RCRA COMPLIANCE AGREEMENTS OR ORDERS RELATING TO MIXED WASTE}

The BCL does not have any RCRA Compliance Agreements or Orders that relate to mixed waste. The $B C L$ is a clean-up project being funded jointly by the DOE and Battelle which is being conducted at a private facility owned by Battelle. The hazardous waste facility is operated by Battelle and used periodically by the project. Operation of the facility is the responsibility of Battelle and not the DOE.

\section{MIXED WASTE CHARACTERIZATION ACTIVITIES FOR FY 1993}

There were no activities conducted during FY 1993 to correct any past formal notifications of RCRA violations of waste characterization activities.

\section{MIXED WASTE STORAGE ACTIVITIES FOR FY 1993}

The DOE is not responsible for the mixed waste storage facilities at the $B C L$.

\section{MIXED WASTE TREATMENT ACTIVITIES FOR FY 1993}

The BCL does not currently have any mixed waste treatment facilities.

\section{MIXED WASTE DISPOSAL ACTIVITIES FOR FY 1993}

The $\mathrm{BCL}$ does not have any mixed waste disposal facilities. 


\section{FERNALD ENVIRONMENTAL MANAGEMENT PROJECT Farnald, Ohio}

Mission: The Fernald Environmental Management Project IFEMPI, formally the Feed Materials Production Center, was constructed in the early 1950 s end was used to produce uranium metal products for use by the Government. Production was suspended in July, 1989. Current FEMP activities focus on the environmental restoration of the site.

\section{RCRA COMPLIANCE AGREEMENTS OR ORDERS RELATING TO MIXED WASTE}

A Consent Decree signed by the State of Ohio and the DOE in December, 1988, established milestones to bring the FEMP into full compliance with RCRA and other regulatory requirements. In January, 1993, amendments establishing additional requirements regarding the management of hazardous waste were made to the Conseit Decree.

In 1986, the DOE and the EPA entered into a Federal Facility Compliance Agreement, in which the DOE agreed to comply with various federal and state regulations, including those under RCRA and the Comprehensive Environmental Response, Compensation, and Liability Act (CERCLA). Consistent with the requirements of Section 120 of CERCLA, a Consent Agreement was signed by the DOE and the EPA in April, 1990 and became effective June 29, 1990. The 1990 Consent Agreement amended the CERCLA portion of the 1986 Federal Facility Compliance Agreement. Under the agreement, the FEMP was divided into five operable units. Remediation schedules were developed for each operable unit to allow the remedial action process to proceed to completion for the most well-defined or problematic areas at the FEMP while data collection and analysis continued for other areas. The remedial actions driven by the Consent Agreement include, but are not limited to, the treatment or disposal of mixed wastes. In September, 1991 the DOE and the EPA jointly signed the Amended Consent Agreement establishing revised milestones for the completion of the required studies and identifying a series of new, near-term actions for implementation by the DOE. In accordance with the Stipulated Amended Consent Decree, the FEMP has completed or initiated four separate activities relating to mixed waste during FY 1993. These include submittal of the RCRA Annual Report, revision of the RCRA Part B Permit Application, additional RCRA training of personnel, and weekly inspections of the mixed waste storage areas. In addition, the FEMP submitted RCRA Closure Plans for several hazardous waste management units during FY 1993.

\section{MIXED WASTE CHARACTERIZATION ACTIVITIES FOR FY 1993}

The last waste characterization activities conducted specifically to correct past formal notifications of RCRA violations were completed in FY 1992 in accordance with the Stipulated Amendment to the Consent Decree entered into on January 22, 1993. Although the Stipulated Amendment to the Consent Decree was not officially signed until January 22, 1993, the FEMP worked toward complying with the terms of the proposed amendments to the Consent Decree prior to the signing of the Stipulated Amendment to the Consent Decree.

\section{MIXED WASTE STORAGE ACTIVITIES FOR FY 1993}

The FEMP has seven mixed waste storage facilities that store mixed low-level waste. These facilities have the total capacity to store $2,431,168 \mathrm{~m}^{3}$ of waste and are operated under the Consent Decree and its stipulated amendments. In addition, the FEMP has 21 satellite accumulation areas that collect and accumulate mixed low-level waste. 
Internal Inspections -- The containers and mixed waste storage areas are inspected weekly by site personnel. All inspections are recorded in inspection logs which are maintained in the FEMP Operating Record. The drums stored in one of the waste storage areas are inspected daily for leakage. Any deteriorations, problems or malfunctions revealed by the inspection are remedied as soon as possible. Any noncompliance items are identified and appropriate parties are notified in accordance with site polices and procedures. Where a hazard is imminent, or has already occurred, remedial action is taken immediately. If the hazard is declared an "emergency" the Contingency Plan is implemented. All other problems are recorded in the inspection log and a work order for correction is placed by the supervisor. Outstanding problems are tracked through completion. Quarterly site assessments are scheduled to be conducted internally to determine RCRA compliance. Assessment reports are completed and sent to the appropriate personnel for follow-up action. No significant compliance problems were identified during FY 1993 at the mixed waste storage facilities.

External Inspections -- The Ohio EPA conducted a routine compliance evaluation inspection of the FEMP in June 1993. The physical inspection of the facility was conducted on June 16 and 17, 1993. The inspection was continued on June 23,1993, in order to review specific records. The FEMP received a Notice of Violation as a result of the inspection conducted during June 1993. The violation addressed storage of wastes restricted from land disposal for a period of time greater than allowed by law. The passage of the FFCAct provides that fines and penalties for violations relating to storage of mixed wastes do not apply for three years (from October 1992), provided DOE complies with all other applicable requirements. The FEMP is conducting actions required under the FFCAct.

Facility Upgrades or Modifications -- Two of the mixed waste storage areas were upgraded to include floor coatings and secondary containment for storage of RCRA hazardous waste. Another mixed waste storage facility is being renovated in accordance with the Removal Action Work Plan. Portions of this renovation were accomplished during FY 1993. The project included the addition of two tension structures and construction of the foundation for the third tension structure. A total of three tension structures are being added to provide covered storage for waste at this storage area.

Permit Modification or Applications -- A revision to the RCRA Part B Permit Application was submitted to the Ohio EPA in March 1993. This revision to the application was submitted in response to a Notice of Deficiency received from the Ohio EPA after its review of the October 1991 submittal.

\section{MIXED WASTE TREATMENT ACTIVITIES FOR FY 1993}

The FEMP plans to stabilize approximately 200,000 gallons of uranyl nitrate hydrate stored in tanks on-site. This activity is being conducted under a CERCLA Removal Action and has been on hold since April, 1993. Operation will commence upon the completion of additional engineering studies and an operational readiness review.

The FEMP also has two additional treatment facilities for low-level waste and mixed low-level waste which are currently operating as pilot scale studies. These facilities have not yet treated any mixed waste.

Internal Inspections -- The uranyl nitrate hydrate tanks are inspected weekly by site personnel. All inspections are recorded in inspection logs which are maintained in the FEMP Operating Record. Any problems or malfunctions revealed by the inspection are remedied as soon as possible. Any noncompliance items are identified and appropriate parties are notified in accordance with site polices and procedures. Where a hazard is imminent, or has already occurred, remedial action is taken immediately. If the hazard is declared an "emergency" the Contingency Plan is implemented. All other problems are recorded in the inspection log and a work order for correction is placed by the supervisor. 
Outstanding problems are tracked through completion. Quarterly site assessments are scheduled to be conducted internally to determine RCRA compliance. Assessment reports are completed and sent to the appropriate personnel for follow-up action.

On April 28, 1993, the FEMP experienced a release of uranyl nitrate hydrate solution from the Plant 2/3. The release was reported to the Ohio EPA on April 28, 1993 and a follow-up report regarding the incident was submitted within 30 days in accordance with the regulations. The uranyl nitrate hydrate was inadvertently pumped into the Plant 8 Digester Tanks along with storm water runoff. As this material was being recovered, a check valve failed in a line to the Plant $2 / 3$ sump. This allowed the diluted uranyl nitrate hydrate solution to exceed the sump capacity and spread over the floor and flow out the door. Approximately $\mathbf{3 0}$ gallons were released.

External Inspections -- No inspections were conducted by the EPA or the State of Ohio during FY 1993.

Facility Uparades or Modifications -- No upgrades or modifications to the mixed waste storage facilities were conducted during FY 1993.

Permit Modifications or Applications -- No RCRA permit modifications or applications relating to mixed waste treatment activities were submitted during FY 1993.

\section{MIXED WASTE DISPOSAL ACTIVITIES FOR FY 1993}

The FEMP does not operate any mixed waste disposal facilities. There are four units which contain mixed waste identified in the FEMP RCRA Part B Permit Application as disposal hazardous waste management units. However, the FEMP is not seeking to permit these units for disposal, and these units are not actively accepting mixed wastes at the FEMP. Current plans are to remediate these units under the FEMP Amended Consent Agreement.

Internal Inspections -- Two of the mixed waste management units are inspected on a weekly basis by site personnel. All inspections are recorded in inspection logs which are maintained in the FEMP Operating Record.

On January 20,1993, the Ohio EPA was notified that the liner of one of the mixed waste management units was inadvertently cut on January 15, 1993. A sample which should have been obtained from a designated test plot was actually taken from the mixed waste management unit liner.

External Inspections -- On September 14, 1993, as required by the FFCAct, the EPA conducted a Comprehensive Monitoring Evaluation of the FEMP's Alternate RCRA Groundwater Monitoring Program. A report of the evaluation is anticipated early FY 1994. The EPA stated that the monitoring program was excellent. No violations are expected.

Facility Upgrades or Modifications -- No upgrades or modifications to the mixed waste management units have been completed during FY 1993.

Permit Modifications or Applications -- No permit modifications or applications relating to mixed waste disposal facilities were submitted during FY 1993. 


\section{MOUND PLANT \\ Dayton, Ohio}

Mission: The Mound Plant has been in continuous use since 1948. Its main mission is to manufacture non-nuclear and tritium-containing components for nuclear weapons which are then assembled at another site. Other activities include the separation, purification, end sale of stable isotopes of the noble gases and research in solar eneroy, fossil fuels, nuclear safeguards, waste management, heat source testing (plutonlum), and fusion fuel systems.

\section{RCRA COMPLIANCE AGREEMENTS OR ORDERS RELATING TO MIXED WASTE}

The Mound Plant currently does not have any RCRA Compliance Agreements or Orders that relate to mixed waste.

\section{MIXED WASTE CHARACTERIZATION ACTIVITIES FOR FY 1993}

There were no activities conducted during FY 1993 to correct any past formal notifications of RCRA violations of waste characterization activities.

\section{MIXED WASTE STORAGE ACTIVITIES FOR FY 1993}

The Mound Plant has one mixed waste storage facility that stores mixed low-level waste. This facility has the capacity to store 45055 -gallon drums $\left(95.6 \mathrm{~m}^{3}\right)$ of waste and is currently operated under interim status.

Internal Inspections -- The mixped waste storage facility is inspected weekly by Waste Management personnel. Any noncompliances identified during these inspections are reported to the Dayton Area Office. No significant compliance problems were identified during FY 1993 at the mixed waste storage facility.

External Inspections -- The Ohio EPA conducted a routine inspection of the mixed waste storage facility on June 23, 1993. No violations were alleged.

Facility Uparades or Modifications -- The mixed waste storage facility is currently undergoing upgrades.

Permit Modifications or Apolications -- The Mound Plant submitted a RCRA Part B Permit Application on January 26, 1993. Comments from the Ohio EPA are still pending.

\section{MIXED WASTE TREATMENT ACTIVITIES FOR FY 1993}

The Mound Plant has one mixed waste treatment facility, a glass melter, that is currently not operational. The trial burn plan was submitted to the Ohio EPA in 1990. The RCRA Part B permit application submitted on January 26, 1993 includes documentation for this treatment facility.

\section{MIXED WASTE DISPOSAL ACTIVITIES FOR FY 1993}

The Mound Plant does not have any mixed waste disposal facilities. 


\section{PORTSMOUTH GASEOUS DIFFUSION PLANT \\ Portsmouth, Ohio}

Mission: The Portsmouth Gaseous Diffusion Plant began operation in 1954 to enrich uranium for national defense and commercial reactors. The Portsmouth Gaseous Diffusion Plant uses gaseous diffusion technology to enrich uranium. In July 1993, the United States Enrichment Corporation, through Congressional legislation, became responsible for uranium enrichment operation for the Portsmouth Gaseous Diffusion Plant. DOE romains responsible for the restoration, waste management, and high enriched uranium suspension programs at the Portsmouth Gaseous Diffusion Plant.

\section{RCRA COMPLIANCE AGREEMENTS OR ORDERS RELATING TO MIXED WASTE}

The Portsmouth Gaseous Diffusion Plant received a Director's Final Findings and Orders from the Ohio EPA on May 18, 1993.

\section{MIXED WASTE CHARACTERIZATION ACTIVITIES FOR FY 1993}

There were no activities conducted during FY 1993 to correct any past formal notifications of RCRA violations of waste characterization activities. However, numerous formal negotiations have been ongoing with the State of Ohio to address the waste characterization issues.

\section{MIXED WASTE STORAGE ACTIVITIES FOR FY 1993}

The Portsmouth Gaseous Diffusion Plant has two mixed waste storage facilities that store mixed lowlevel waste. These facilities have the capacity to store $21,261 \mathrm{~m}^{3}$ of mixed waste and are currently operated under an Ohio EPA Director's Findings and Orders. The two storage facilities have special requirements for nuclear criticality safety which include spacing at discrete distances, storage in specially designed containers depending on uranium assay, and a maximum one-inch dike height.

Internal Inspections -- The mixed waste storage ?acilities are inspected by trained inspectors on a weekly basis. Any noncompliances are noted and tracked until resolution. No significant compliance problems were identified during FY 1993 at the mixed waste storage facilities.

External Inspections -- The Ohio EPA conducted a routine RCRA inspection on August 2, 3, and 4, 1993. Four violations were alleged.

Facility Upgrades or Modifications -- During FY 1993 three mixed waste storage tanks underwent RCRA closure. The three tanks were the subject of previous Notices of Violations received from the Ohio EPA.

Permit Modifications or Applications -- The Portsmouth Gaseous Diffusion Plant revised its RCRA permit applications and submitted it to the Ohio Hazardous Waste Facilities Board on July 26, 1993. These changes reflect the operational responsibilities of the DOE and the United States Enrichment Corporation. The Ohio Hazardous Waste Facilities Board is reviewing the RCRA permit application and is planning to visit the site to tour the waste storage areas. 


\section{MIXED WASTE TREATMENT ACTIVITIES FOR FY 1993}

The Portsmouth Gaseous Diffusion Plant has six wastewater treatment facilities operating under permitby-rule provisions of RCRA that treat mixed low-level waste. There is one wastewater treatment facility under construction that will replace one of the operating facilities. The Portsmouth Gaseous Diffusion Plant has another wastewater treatment facility that is currently non-operational but with appropriate permitting and modifications could treat mixed waste.

Internal Inspections -- The mixed waste treatment facilities are inspected by trained personnel on a daily basis if the facility is in operation. Inspections are recorded on an operational checklist. No significant compliance problems were identified during FY 1993 at the mixed waste treatment facilities.

External Inspections -- No inspections were conducted during FY 1993 by the EPA or the State of Ohio.

Facility Uparades or Modifications -- No upgrades or modifications to the mixed waste treatment facilities were conducted during FY 1993.

Permit Modifications or Applications -- No permit modifications or applications relating to mixed waste treatment facilities were submitted during FY 1993.

\section{MIXED WASTE DISPOSAL FACILITIES}

The Portsmouth Gaseous Diffusion Plant does not have any operating mixed waste disposal facilities. One mixed waste disposal area was closed under RCRA during FY 1993. 


\section{RMI TITANIUM COMPANY, EXTRUSION PLANT}

Ashtabula, Ohio

Mission: The RMI Titanium Company (RMI) had operated an extrusion press to extrude depleted, normal, and slightly enriched uranium under contract with DOE and its predecessor agencies from 1962 to 1990 . Years of handling, extruding, forging, machining, and processing uranium at the RMI facility have resulted in onsite and offsite contamination. Environmental restoration activities Include remediation of local groundwater, surface soils, and buildings.

\section{RCRA COMPLIANCE AGREEMENTS OR ORDERS RELATING TO MIXED WASTE}

The RMI requested and received an exemption from the Ohio EPA on October 22, 1992 authorizing the storage of 332 drums of barium salt bath waste. The RMI received an 180-day Temporary Authorization Determination from the EPA Region V on June 9, 1993 for the same material. These agreements allow the RMI to store the drums of salt bath waste, which have been classified as mixed low-level waste, at the new storage facility pending approval of the applications for that facility.

\section{MIXED WASTE CHARACTERIZATION ACTIVITIES FOR FY 1993}

There are no current or past formal RCRA violations of waste characterization activities; no characterization activities were conducted during FY 1993.

\section{MIXED WASTE STORAGE ACTIVITIES FOR FY 1993}

The RMI has one waste storage facility permitted through the EPA Region V. This storage facility has the capacity to store 109 55-gallon drums of mixed low-level waste. The RMI has a permit application pending with the Ohio EPA for this storage area, plus a second waste storage area with a proposed storage capacity of 500 55-gallon drums, as described above under the section on RCRA Compliance Agreements.

Internal inspections -- The mixed waste storage facilities, including the emergency equipment, are inspected weekly by an Environmental Engineer. Any noncompliances identified during these inspections are noted. Correction of the noncompliances, and review and approval of the inspections are completed by the Manager of Operations and the Manager of Environmental Safety and Health. No significant compliance problems were identified during FY 1993 at the mixed waste storage facilities.

External Inspections -- The State of Ohio conducts annual routine inspections of the RCRA program including the mixed waste storage facility. The most recent inspection was completed on June 1, 1993. No violations were noted during this inspection.

Facility Upgrades or Modifications -- An increase in mixed waste storage capacity is being undertaken, as discussed above.

Permit Modifications or Applications -- The RMI submitted a RCRA storage permit class 1 modification (administrative changes) to the Ohio EPA on March 5, 1993. The RMI also submitted a revised permit application to the Ohio EPA to increase the mixed waste storage capacity by adding another storage facility, as discussed above. This application is still pending. 
MIXED WASTE TREATMENT ACTIVITIES FOR FY 1993

The RMI does not have any mixed waste treatment facilities.

MIXED WASTE DISPOSAL ACTIVITIES FOR FY 1993

The RMI does not have any mixed waste disposal facilities. 
This page intentionally left blank. 


\section{SOUTH CAROLINA}


This page intentionally left blank. 


\section{CHARLESTON NAVAL SHIPYARD \\ Charleston, South Carolina}

Mission: The Charleston Naval Shipyard is a U.S. Department of Navy facility that repairs, overhauls, and maintains Navy ships, including nuclear-powered ships. Drydocks, cranes, waste handling tacilities, and offices are located at the shipyard. Activities supporting nuclear propulsion systems are performed in accordance with the requirements and authority of the Naval Nuclear Propulsion Program, a joint DOE and U.S. Department of Navy program responsible for all activities relating to naval nuclear propulsion.

\section{RCRA COMPLIANCE AGREEMENTS OR ORDERS RELATING TO MIXED WASTE}

The Charleston Naval Shipyard currently does not have any RCRA Complianr: Agreements or Orders that relate to mixed waste.

\section{MIXED WASTE CHARACTERIZATION ACTIVITIES FOR FY 1993}

There were no activities conducted during FY 1993 to correct any past formal notifications of RCRA violations of waste characterization activities.

\section{MIXED WASTE STORAGE ACTIVITIES FOR FY 1993}

The Charleston Naval Shipyard has one designated mixed waste storage facility with the capacity to store $220 \mathrm{~m}^{3}$ of mixed low-level waste.

Internal Inspections -- The mixed waste storage facility is inspected weekly and monthly by facility operators and oversight personnel to ensure compliance with requirements. Any noncompliances are reported to the cognizant technical personnel for resolution. No significant compliance problems were identified during FY 1993 at the mixed waste storage facility.

External Inspections -- No inspections were conducted by the EPA or the State of South Carolina during FY 1993.

Facility Upgrades or Modifications -- The mixed waste storage facility has been modified with the addition of an automatic remote fire alarm system that is tied into the Charleston Naval Base fire department.

Permit Modifications or Applications -- The Charleston Naval Shipyard submitted a revision to its RCRA Part B permit to allow storage of mixed waste in Building 246. The Charleston Naval Shipyard is awaiting approval for this revision from the South Carolina Department of Health and Enviroımental Control.

\section{MIXED WASTE TREATMENT ACTIVITIES FOR FY 1993}

The Charleston Naval Shipyard does not have any mixed waste treatment facilities.

\section{MIXED WASTE DISPOSAL ACTIVITIES FOR FY 1993}

The Charleston Naval Shipyard does not have any mixed waste disposal facilities. 


\section{SAVANNAH RIVER SITE \\ Aiken, South Carolina}

Mission: The mission of the Savannah River Site (SRS) is to serve the national security interest of the United States by safely processing nuclear materials while protecting employee and public health and the environment. A key installation for nuclear materials processing and research for DOE, it is managed by DOE's Savannah River Field Office and operated under contract by the Westinghouse Savannah River Company. This unique industrial complex covers some 192,000 acres, or 300 square miles, encompassing parts of three counties in western South Carolina bordering the Savannah River. Waste management operations and environmental monitoring at SRS employ the latest technology to ensure the safety of employees and the public.

\section{RCRA COMPLIANCE AGREEMENTS OR ORDERS RELATING TO MIXED WASTE}

The SRS has twelve agreements or orders relating to the management of mixed waste that were effective during FY 1993. These include the following:

- Land Disposal Restriction Federal Facility Compliance Agreement

- Effective March, 1991

- Amended April, 1992 and April, 1993

- Currently under negotiation for amendment

- South Carolina Department of Health and Environmental Control Settlement Agreement 91-51-SW

- Executed August 26, 1991

- Addresses disposal of solvent rags

- South Carolina Department of Health and Environmental Control Settlement Agreement 90-64-SW

- Executed September 5, 1990

- Addresses accumulation of waste exceeding 90 days

- South Carolira Department of Health and Environmental Control Settlement Agreement 86-52-SW

- Executed October 6, 1986

- Addresses a drumming incident and operation of a liquid effluent treatment facility

- South Carolina Department of Health and Environmental Control Settlement Agreement 86-96-SW

- Executed October 6, 1986

- Addresses a drumming incident

- South Carolina Department of Health and Environmental Control Settlement Agreement 87-27-SW-B

- $\quad$ Executed June 15, 1989

- Amendment concerning post-closure Part B Permit Application for two seepage basins

- South Carolina Department of Health and Environmental Control Settlement Agreement 87-27-SW

- Executed May 1, 1987

- Addresses revised Part B Permit Application 
- South Carolina Department of Health and Environmental Control Settlement Agreement 87-51-SW

- $\quad$ Executed November 12, 1987

- Addresses an EPA Multimedia Inspection Violation

- South Carolina Department of Health and Environmental Control Settlement Agreement 87-52-SW

- Executed May 10, 1991

- Addresses mixed waste management facility closure and post-closure

- South Carolina Department of Health and Environmental Control Settlement Agreement 88-28-SW

- Executed November 30, 1988

- Addresses an EPA compliance monitoring evaluation violation

- South Carolina Department of Health and Environmental Control Settlement Agreement 92-17-SW

- $\quad$ Executed April 23, 1992

- Addresses 1990 comprehensive monitoring evaluation violations against the DOE

- South Carolina Department of Health and Environmental Control Consent Order 92-35-SW

- Executed July 7, 1992

- Addresses 1990 comprehensive monitoring evaluation violations against Westinghouse Savannah River Company

\section{MIXED WASTE CHARACTERIZATION ACTIVITIES FOR FY 1993}

There were no activities conducted during FY 1993 to correct any past formal notifications of RCRA violations of waste characterization activities.

\section{MIXED WASTE STORAGE ACTIVITIES}

The SRS has a total of 13 storage facilities that store mixed waste including mixed low-level waste, mixed transuranic waste, and high-level waste. These 13 facilities have the total capacity to store $252,595 \mathrm{~m}^{3}$ of mixed waste. Ten of the 13 storage facilities are operated under interim status; one under permitted status; and the remaining two are operating under wastewater permits. The SRS also has 64 satellite accumulation areas and 13 staging areas.

Internal Inspections --

- Solid Waste Operations personnel inspect the mixed transuranic and mixed low-level waste container storage facilities on a weekly basis. Any noncompliances identified during these inspections are corrected immediately, if possible. If the corrective action requires a work order to complete, the work order number is recorded on inspection forms, logged and tracked until completion.

- Tanks containing high-level and mixed low-level wastes are inspected by RCRA trained area personnel daily. In addition the tanks are continually monitored and inspected for leaks. Integrity inspections are conducted periodically. The Environmental Coordinator also conducts monthly inspections of the RCRA daily log for two of the five tank storage facilities. Any noncompliances identified during these inspections are reported to responsible area management and to the Site Item Reportability and Issue Management System which initiates notification, assessment, investigation, significance determination, and corrective action. 
- Mixed waste tank storage is inspected twice daily. Mixed waste container storage area is inspected weekly. Any non-compliances identified during these inspections are tracked until corrective action is implemented and documented.

A Comprehensive Compliance Assurance Review is conducted by the DOE-Savannah River Environmental Compliance Division at least once every three years. Any non-compliances identified during this review are reported to the appropriate SRS organization, who is requested to respond to DOE-Savannah River Operations Office by a specific date.

- The following compliance problems were addressed at the SRS during FY 1993:

- Noted a floor coating problem at one storage facility in August, 1991. Problem reported to South Carolina Department of Health and Environmental Control in August, 1991. Completed floor coating repair during the first quarter of Calendar Year 1993.

- Rainwater identified in drums stored on the transuranic waste storage pads in March, 1989. Problem reported to South Carolina Department of Health and Environmental Control in March, 1989. Dewatering of drums is currently in progress.

- Noted that culverts containing hazardous waste were improperly stored on the gravel loading area adjacent to the transuranic waste pads in May, 1993. Problem reported to the South Carolina Department of Health and Environmental Control on the Quarterly Hazardous Waste Report in July, 1993. Culverts were relocated and a procedure implemented to prevent reoccurrence of the problem.

- Some waste storage tanks were unable to meet Subpart $J$ Tank requirements. Variance petitions were submitted to the South Carolina Department of Health and Environmental Control on September 24, 1991 and were denied on April 10, 1992. A RCRA Closure Plan was submitted to the South Carolina Department of Health and Environmental Control on August 11,1992 to address this problem. Activities in support of the Closure Plan have been ongoing. A June 18, 1993 letter to the South Carolina Department of Health and Environmental Control identified schedule for integrity testing.

- Noted a missing inspection record for the high-level tank farms in the 4th Quarter, 1992. Reported the problem to the South Carolina Department of Health and Environmental Control on January 19, 1993. Implemented revised procedures for the management of inspection records to correct this problem.

- Identified data fluctuations for the high-level tank farms in 4th Quarter, 1992 and reported the problem to the South Carolina Department of Health and Environmental Control in January, 1993. Implemented improved methods for collecting inventory data to correct this problem.

- Noted that three inspection records were missing for the Defense Waste Processing Facility Organic Waste Storage Tanks in June, 1993. Problem reported to the South Carolina Department of Health and Environmental Control in July, 1993. Relocated place where inspection records are kept to address this problem.

- Identified the need for an aisle-spacing variance for transuranic waste storage pads. Reported the problem to the South Carolina Department of Health and Environmental Control on June 18, 1991, and submitted a variance request on May 11, 1993. 
External Inspections -- The South Carolina Department of Health and Environmental Control conducted an annual comprehensive monitoring evaluation on May 10-19, 1993. The South Carolina Department of Health and Environmental Control issued a letter noting that no deficiencies were found during the evaluation.

Facility Upgrades or Modifications -- The SRS conducted several facility upgrades or modifications during FY 1993 including installation of replacement solvent storage tanks (ongoing) and installation of emergency transfer pumps for two additional waste storage tanks.

Permit Modifications or Applications -- The SRS submitted the following permit modifications or revisions during FY 1993:

- On November 5, 1992, submitted a modification to the 1992 Part B Permit Application for the Defense Waste Processing Facility Organic Waste Storage Tanks in response to a Notice of Deficiency received on September 22, 1992. The approval for this modification is still pending.

- On December 2, 1992, submitted a modification to the 1985 Part B Permit Application for changes in the Hazardous Waste Storage Facility's fencing. This modification was approved by the South Carolina Department of Hisalth and Environmental Control on January 28, 1993.

- On January 11, 1993, submitted a modification to the 1992 Part B Permit Application for the Defense Waste Processing Facility Organic Waste Storage Tank to address changes in liquid level required to float the tank roof. The South Carolina Department of Health and Environmental Control issued a Notice of Deficiency on September 22, 1993.

- On February 11, 1993, submitted a general revision to the 1992 Parr B Permit Application, Volume I. The approval for this modification is still pending.

- On February 16, 1993, submitted a modification to the Part A Permit to add three storage units and revise solvent tank capacity. The approval of this modification is still pending.

- On March 5, 1993, submitted a modification to the 1985 Part B Permit Application to address changes in the Hazardous Waste Storage Facility's curbing. The approval for this modification is still pending.

- On July 19, 1993, submitted a modification to the 1992 Part B Permit Application for the Hazardous Waste Storage Facility in response to a Notice of Deficiency received on June 2, 1993.

\section{MIXED WASTE TREATMENT ACTIVITIES}

The SRS has five treatment facilities that treat mixed low-level waste that are currently operating. Three of these facilities are operated under wastewater treatment permits. The SRS also has three mixed waste treatment facilities under construction.

Internal Inspections -- Three of the treatment facilities are currently operating under wastewater treatment permits. Therefore, RCRA compliance inspections are not performed. All inspections required by the wastewater treatment permit are conducted by state certified wastewater operators on a daily basis. The other treatment facilities are inspected daily by RCRA trained area personnel. In addition, the Environmerital Coordinator monitors the daily log monthly. 
A Comprehensive Compliance Assurance Review is conducted by the DOE-Savannah River Environmental Compliance Division at least once every three years. Any non-compliances identified during this review are reported to the appropriate SRS organization, who is requested to respond to DOE-Savannah River Operations Office by a specific date.

External Inspections -- The South Carolina Department of Health and Environmental Control conducted a routine annual audit of the mixed waste treatment facilities on October 19-30, 1992. No deficiencies or recommendations were noted.

Facility Uparades or Modifications -- The SRS conducted several facility upgrades or modifications during FY 1993 including replacement of level gauges and installation of emergency transfer pumps for two waste tanks.

Permit Modifications or Applications -- The SRS submitted the following permit modifications or revisions during FY 1993:

- On February 16, 1993, submitted a modification to the Part A Permit to add two treatment units. The approval of this modification is still pending.

- On March 15, 1993, submitted a modification to the Tank Farm Wastewater Treatment Permit for the Auxillary Pump Pit By-Pass. This modification was approved by the South Carolina Department of Health and Environmental Control on April 30, 1993.

- On April 12, 1993, sukmitted a modification to the Defense Waste Processing Facility Wastewater Treatment Permit to addendum for the Cold Chemical Run. This modification was approved by the South Carolina Department of Health and Environmental Control on April 30, 1993.

- On May 3, 1993 submitted a Part B Permit Renewal Application (Revision 0) for the Consolidated Incineration Facility. The South Carolina Department of Health and Environmental Control issued a Notice of Deficiency on July 16, 1993.

- On July 27, 1993, submitted a modification to the Defense Waste Processing Facility Wastewater Treatment Permit for Hydrogen Ammonia Mitigation. This modification was approved by the South Carolina Department of Health and Environmental Control on April 30, 1993.

- On August 16, 1993, submitted a modification to the 1992 Part B Permit Application for the Consolidated Incineration Facility in response to a Notice of Deficiency received on July 16, 1993. The approval for this modification is still pending.

Other permit modification submittals are discussed under the mixed waste storage activities section.

\section{MIXED WASTE DISPOSAL ACTIVITIES}

The SRS does not have any mixed waste disposal facilities. 


\section{TENNESSEE}


This page intentionally left blank.

CHIEF FINANCIAL OFFICER'S REPORT -1993

A-102 


\section{K-25 SITE - OAK RIDGE RESERVATION Oak Ridge, Tennessee}

Mission: The K-25 Site was a production and development facility for uranium enrichment. Production operations at K-25 were shut down in 1985 . The present mission of K-25 is environmental restoration, decontamination and decommissioning, waste management, and providing support for other government agencles in the Work-for-Others program.

\section{iTCRA COMPLIANCE AGREEMENTS OR ORDERS RELATING TO MIXED WASTE}

The K-25 Site is included under the Oak Ridge Reservation Land Disposal Restrictions Federal Facility Compliance Agreement negotiated with the EPA on June 12, 1992. Five deliverables were completed during FY 1993 in compliance with this agreement.

\section{MIXED WASTE CHARACTERIZATION ACTIVITIES FOR FY 1993}

There were no activities required during FY 1993 to correct any past formal notifications of RCRA violations of waste characterization activities.

\section{MIXED WASTE STORAGE ACTIVITIES}

The K-25 Site Waste Management Division has 32 storage facilities that store mixed low-level waste. These facilities are permitted facilities and have the total capacity to store $33,202 \mathrm{~m}^{3}$ of waste plus an additional 180,000 gallons. The K-25 Site Waste Management Division also has six satellite accumulation areas and two 90-day storage areas.

Internal Inspections -- The Waste Management Division personnel inspect the mixed waste container storage facilities and 90-day accumulation units weekly and the tank storage units daily. Any noncompliances identified during these inspections are reported as required by the permits. No significant compliance problems were identified during FY 1993 at the mixed waste storage facilities.

External Inspections -- The Tennessee Department of Environment and Conservation conducted a routine inspection of the mixed waste storage facilities, the satellite accumulation areas, and the 90day storage areas in June, 1993. The Tennessee Department of Environment and Conservation also conducted a routine air inspection of the mixed waste storage facilities in July 1993. No violations were alleged.

Facility Uparades or Modifications -- The K-25 Site completed two lighting upgrades in two Waste Management Division storage vaults during FY 1993.

Permit Modifications or Applications -- The K-25 Site submitted a permit modification request and received approval to install polyvinyl chloride dikes in 18 mixed waste storage vaults in accordance with plans currently in the permit. 


\section{MIXED WASTE TREATMENT ACTIVITIES}

The K-25 Site has three treatment facilities that treat mixed low-level waste. Two of these facilities are permit-by-rule facilities under RCRA and the other is operated under a RCRA permit. Two facilities are operational; the other is on standby status.

Internal Inspections -- The mixed waste treatment facilities are inspected weekly by operations personnel. Any noncompliances identified during these inspections are reported to the front line supervisor. No significant compliance problems were identified in terms of the operation of the facility. However, in December, 1992, it was identified that several temperature readings at one of the treatment facilities had not been collected as required by the permit. Notification to the Tennessee Department of Environment and Conservation was made in January, 1993.

External Inspections -- The Tennessee Department of Environment and Conservation conducted a routine annual Air inspection in July, 1993 and the EPA also conducted a routine Air inspection in September, 1993 of the K-25 TSCA Incinerator. In response to a Notice of Violation issued by the Tennessee Department of Environment and Conservation on December 2, 1992 regarding the overfeeding of aqueous waste to the incinerator, new liquid waste flow meters with smaller operating ranges were installed to reduce erroneous indications when operating at the lower end of a larger scale.

Facility Uparades or Modifications -- The K-25 Site initiated design for adding organic removal capability at one of the treatment facilities. This action is not to correct a deficiency, but to expand the facility's treatment capabilities. The ionizing wet scrubbers were replaced at the K-25 TSCA Incinerator facility in November, 1992.

Permit Modifications or Apolications -- A RCRA Permit modification was submitted on September 3 , 1993 for the K-25 TSCA Incinerator. The facility is currently waiting for approval from the Tennessee Department of Environment and Conservation.

\section{MIXED WASTE DISPOSAL ACTIVITIES}

The K-25 Site does not have any mixed waste disposal facilities. 


\section{OAK RIDGE NATIONAL LABORATORY- OAK RIDGE RESERVATION \\ Oak Ridge, Tennesser}

Mission: The Oak Ridge National Laboratory IORNLL provides extensive research and development in eneroy production and related technologies. Activities include reactor and accelerator: development and operation, production and sale of radioactive and stable isotopes, and environmental and health research.

\section{RCRA COMPLIANCE AGREEMENTS OR ORDERS RELATING TO MIXED WASTE}

The ORNL is included under the Oak Ridge Reservation Land Disposal Restrictions Federal Facility Compliance Agreement negotiated with the EPA on June 12, 1992. Five deliverables were completed during FY 1993 in compliance with this Agreement.

\section{MIXED WASTE CHARACTERIZATION ACTIVITIES FOR FY 1993}

There were no activities required during FY 1993 to correct any past formal notifications of RCRA violations of waste characterization activities.

\section{MIXED WASTE STORAGE ACTIVITIES}

The ORNL. Waste Management Division has sixteen mixed waste storage facilities. Nine of these facilities store mixed low-level waste; the remaining seven store mixed transuranic wastes. These facilities have the capacity to store 84,990 gallons plus $30,000 \mathrm{ft}^{3}$ of mixed low-level waste and 1,437 $\mathrm{m}^{3}$ of transuranic waste. Fourteen of the storage facilities are operated under a Part B permit; the remaining two are operated under a RCRA permit-by-rule.

Internal Inspections -- The mixed waste storage facilities are inspected by Waste Management Operations personnel according to the requirements specified in the permits. Some of the permit requirements for inspections have been waived for mixed transuranic waste storage facilities due to health and safety considerations. Any noncompliances identified during these inspections are reported to the site compliance office, who in turn notifies the Tennessee Department of Environment and Conservation. No significant compliance problems were identified during FY 1993 at the mixed waste storage facilities.

External Inspe ons -- The Tennessee Department of Environment and Conservation conducted a routine inspection of permitted mixed waste storage facilities on June 14 through $16,1993$. No violations were alleged.

Facility Upgrades or Modifications -- One of the storage facilities was upgraded to improve secondary containment, fire doors, and unit roof.

Permit Modifications or Applications -- No RCRA permit modifications or applications relating to mixed waste were submitted during FY 1993. 


\section{MIXED WASTE TREATMENT ACTIVITIES}

There are currently no RCRA permitted mixed waste treatment facilities operating at ORNL, nor have there been any in FY 1993. There are two wastewater treatment facilities that treat mixed waste. These facilities are operating under the permit-by-rule provisions of RCRA.

\section{MIXED WASTE DISPOSAL ACTIVITIES}

The ORNL currently has one disposal facility that is undergoing a RCRA closure. No active mixed waste disposal has taken place at this facility during FY 1993.

Internal Inspections -- The mixed waste disposal facility is inspected weekly to determine the integrity of the cap material. An overall inspection of the perimeter is conducted on a monthly basis. Any noncompliances are reported to the site compliance office, who in turn notifies the Tennessee Department of Environment and Conservation. No significant compliance problems were identified during FY 1993 at the mixed waste disposal facility.

External Inspections -- The Tennessee Department of Environment and Conservation conducted a routine groundwater monitoring inspection in August, 1993. No violations were alleged.

Facility Upgrades or Modifications -- No upgrades or modifications to the mixed waste disposal facility were conducted during FY 1993.

Permit Modifications or Applications -- No RCRA permit modifications or applications relating to mixed waste were submitted during FY 1993. 


\section{Y-12 PLANT - OAK RIDGE RESERVATION Oak Ridge, Tennessee}

Mission: The Y 12 Plant's original mission was to separate the fissionable isotope of uranium IU. 2351 by the electromagnetic process. The plant today has four principal missions: to dismantle nuclear weapon components, to provide special production support to the DOE programs, to support the ORNL research programs, and to serve as a manufacturing, technology, and demonstration center.

\section{RCRA COMPLIANCE AGREEMENTS OR ORDERS RELATING TO MIXED WASTE}

The Y-12 Plant is included in Oak Ridge Reservation Land Disposal Restrictions Federal Facility Compliance Agreement negotiated with the EPA on June 12, 1992. Five deliverables were completed during FY 1993 in compliance with this Agreement.

\section{MIXED WASTE CHARACTERIZATION ACTIVITIES FOR FY 1993}

There were no activities required during FY 1993 to correct any past formal notifications of RCRA violations of waste characterization activities.

\section{MIXED WASTE STORAGE ACTIVITIES}

The Y-12 Plant Waste Management Division has nine storage facilities that store mixed low-level waste. These facilities have the capacity to store 1,929,335 gallons of waste and are currently operated under interim status.

Internal Inspections -- The mixed waste storage facilities are inspected weekly by trained inspectors from the Environmental Management Department. Any noncompliances identified during these inspections are noted and reported to the Compliance Office Coordinator. No significant compliance problems were identified during FY 1993 at the mixed waste storage facilities.

External Inspections -- The Tennessee Department of Environment and Conservation conducted a routine inspection of the mixed waste storage facilities, 90-day storage areas, and satellite accumulation areas on July 14 through 17,1993 . No violations were alleged.

Facility Upgrades or Modifications -- No upgrades or modifications to the mixed waste storage facilities were conducted during FY 1993.

Permit Modifications or Applications -- No RCRA permit modifications or applications relating to mixed waste storage facilities were submitted during FY 1993.

\section{MIXED WASTE TREATMENT ACTIVITIES}

The Y-12 Plant currently has five treatment facilities that treat mixed low-level waste. Two of these facilities are permit-by-rule facilities under RCRA and the other three are operated under wastewater treatment permits. An additional facility is under construction and will be under a RCRA permit-by-rule as a pilot scale facility. 
Internal Inspections -- The mixed waste treatment facilities are inspected weekly by trained inspectors from Environmental Management Department. Any noncompliances identified during these inspections are noted and reported to the RCRA Compliance Office Coordinator. On February 26, 1993, the State of Tennessee was notified that wastewater from one of the treatment facilities was sent to the ORNL prior to passing the regulated point of discharge and not properly manifested.

External Inspections -- The Tennessee Department of Environment and Conservation conducted a routine inspection of all mixed waste treatment facilities on July 14 through 17,1993 . No violations were alleged.

Facility Uporades or Modifications -- No upgrades or modifications to the mixed waste treatment facility were conducted during FY 1993.

Permit Modifications or Applications -- No RCRA permit modifications or applications relating to mixed waste treatment facilities were submitted during FY 1993.

\section{MIXED WASTE DISPOSAL ACTIVITIES}

The Y-12 Plant does not have any mixed waste disposal facilities. 


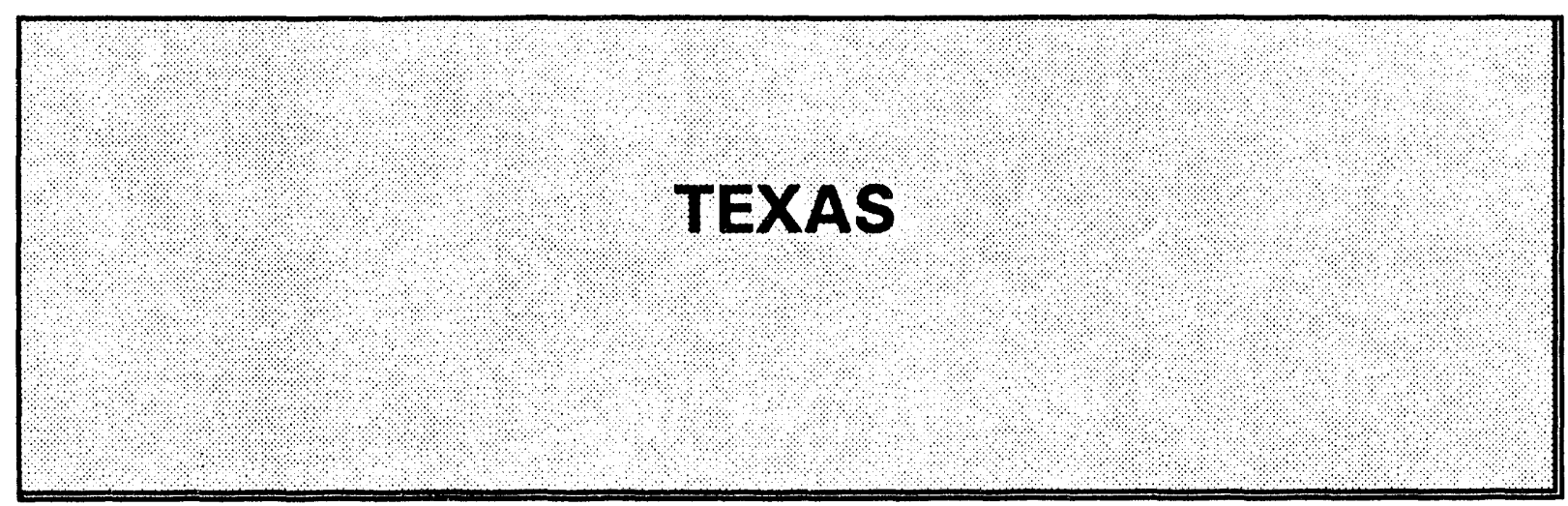


This page intentionally left blank. 


\section{PANTEX PLANT \\ Amarillo, Texas}

Mission: The facility was first used in 1942 by the Army Ordnance Corps for loading conventional ammunition shells and bombs and was rehabilitated in 1950 for use in nuclear weapons operations. The Pantex Plant's current functions include the fabrication of chemical high explosives; high. explosives development work in support of the desion laboratories; and nuclear weapons assembly, disassembly, testing, quality assurance, repair, retirement, and disposal.

\section{RCRA COMPLIANCE AGREEMENT OR ORDERS RELATING TO MIXED WASTE}

The Pantex Plant currently does not have any RCRA Compliance Agreements or Orders that relate to mixed waste.

\section{MIXED WASTE CHARACTERIZATION ACTIVITIES FOR FY 1993}

There were no activities conducted during FY 1993 to correct any past formal notifications of RCRA violations of waste characterization activities.

\section{MIXED WASTE STORAGE ACTIVITIES FOR FY 1993}

The Pantex Plant has eight conexes, one igloo and a pad that store mixed low-level waste. These storage units have the total capacity to store 1,368 55-gallon drums of waste.

Internal Inspections -- The mixed waste storage units are inspected weekly by the Waste Management Solid Waste Compliance Group. Any noncompliances identified during these inspections are reported to the user group via memorandum. No significant compliance problems were identified during FY 1993 at the mixed waste storage units.

Externial Inspections -- The State of Texas Water Commission conducted an annual inspection of the mixed waste storage units on August 10, 1993. No violations were alleged.

Permit Modifications or Applications -- The Pantex Plant submitted a RCRA permit modification to the State of Texas Water Commission and the EPA in April 1993 to add new storage locations. This modification is currently under review by the regulators.

\section{MIXED WASTE TREATMENT ACTIVITIES FOR FY 1993}

The Pantex Plant has one mixed waste treatment facility that is pending approval of the RCRA permit modification to begin operation. The RCRA permit modification was submitted to the State of Texas Water Commission and the EPA on December 31, 1992. The permit modification is currently under review by the regulators.

\section{MIXED WASTE DISPOSAL ACTIVITIES FOR FY 1993}

The Pantex Plant does not have any mixed waste disposal facilities. 
This page intentionally left blank. 


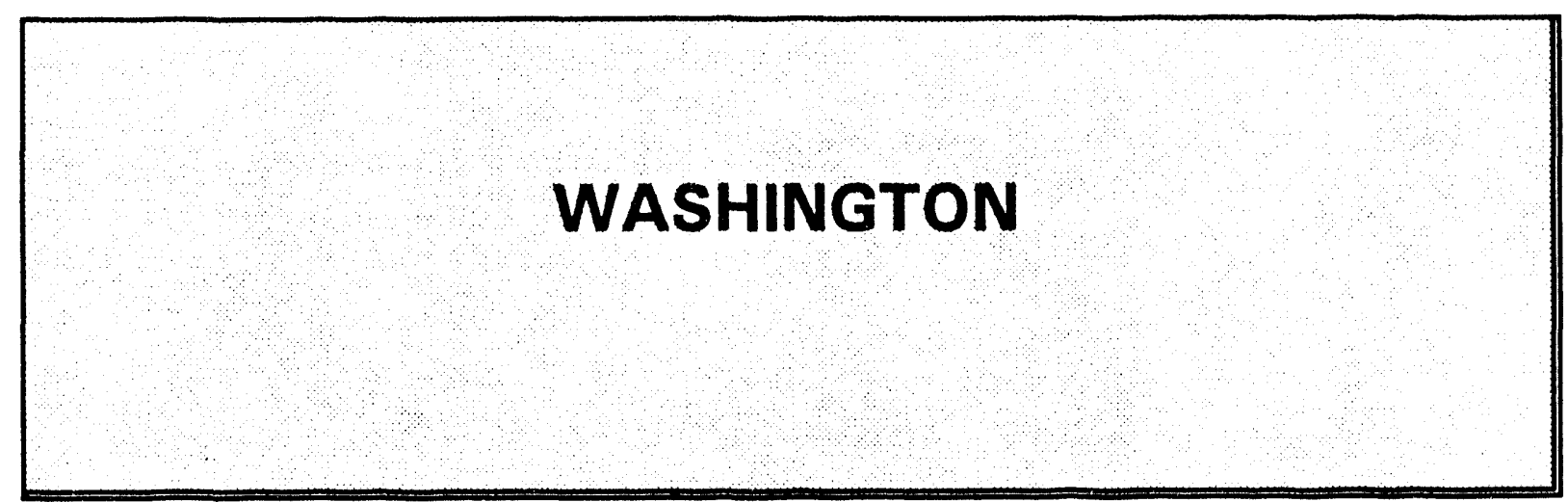


This page intentionally left blank. 


\section{HANFORD SITE \\ Richland, Washington}

Mission: Chosen in 1943 for the Manhattan Project, the Hanford Site was used to produce plutonium for the world's first nuclear weapons. Today, the focus of activities is site cleanup and onvironmental restoration; scientific and environmental research; and development and application of radioactive waste and hazardous waste management technologies.

\section{RCRA COMPLIANCE AGREEMENTS OR ORDERS RELATING TO MIXED WASTE}

The Hanford Site is currently operating under the Hanford Federal Facility Agreement and Consent Order, Volumes 1 and 2 as amended, 1990 (also referred to as the Tri-Party Agreement) negotiated among the EPA, Washington Department of Ecology, and the DOE. Nine separate milestones required by the Tri-Party Agreement were completed during FY 1993.

The Hanford Site is also operating under a Consent Order issued on March 10, 1993, by the Washington Department of Ecology. This Consent Order addresses the storage of approximately 2,000 containers of mixed waste. The failure to adequately designate the waste was discovered during a DOE internal audit. As a result, the Washington Department of Ecology issued the Consent Order on March 10, 1993.

\section{MIXED WASTE CHARACTERIZATION ACTIVITIES FOR FY 1993}

There were no activities conducted during FY 1993 to correct any past formal notifications of RCRA violations of waste characterization activities.

\section{MIXED WASTE STORAGE ACTIVITIES FOR FY 1993}

The Hanford Site has 18 facilities that currently store mixed waste, two of which store mixed low-level waste; the other 16 facilities store mixed low-level, mixed transuranic, and high-level waste. These 18 facilities can be divided into two groups: eight that no longer actively receive waste and ten that are receiving or could receive waste for storage to await treatment and disposal. Sixteen of these facilities are covered under existing permits or the Tri-Party Agreement and the other two are operating under interim status. Seventeen of these facilities have the total permitted capacity to store $1,701,000 \mathrm{~m}^{3}$ of waste and the other facility has the capacity to store $113 \mathrm{~m}^{3}$ of waste. This other facility's capacity is limited by radionuclide content and, therefore, is not included in the total for permitted capacity.

Internal Inspections -- Self-assessments are conducted at 16 of the 18 facilities. These selfassessments consist of a number of inspections and surveys. Any noncompliances identified during these self-assessments are identified and tracked to resolution. In addition to self-assessments, the Environmental, Safety and Compliance Assurance Groups conduct audits, appraisals, and surveillances. The RCRA Compliance Support group provides guidance and oversight directly to the facilities. The frequency of inspections for these 16 mixed waste storage facilities is based on an internal priority ranking system, where resources are allocated to activities that address the worst potential for environmental problems. Any noncompliances identified during these inspections are entered into a database, assigned a priority planning grid value, and tracked to resolution. The remaining two mixed waste storage facilities are inspected daily when waste is being handled and weekly by the operating 
staff, monthly and weekly by management, and annually by the Environmental Compliance Oversight Group. Any noncompliance for these two mixed waste storage facilities are reported through the unusual occurrence reporting system.

During an internal inspection, it was identified that very high activity debris generated during the clean out of one of the mixed waste storage facilities was mixed waste. Five drums of this mixed waste were collected and stored. However, the storage of this waste exceeded the 90-day accumulation limit. The Hanford Site notified the EPA and the Washington Department of Ecology. The Washington Department of Ecology stated that no further notification is required.

External Inspections -- The Washington State Department of Ecology conducted 27 separate inspections of the mixed waste storage facilities during FY 1993. The EPA conducted two inspections of the storage facilities during FY 1993 and both the EPA and the Washington State Department of Ecology conducted a joint inspection at one of the mixed waste storage facilities. No violations were alleged.

Facility Uparades or Modifications -- No upgrades or modifications of the mixed waste storage facilities were conducted during FY 1993.

Permit Modifications or Applications -- No RCRA permit modifications or applications relating to mixed waste storage facilities were submitted during FY 1993.

\section{MIXED WASTE TREATMENT ACTIVITIES FOR FY 1993}

The Hanford Site has two treatment facilities, one that is fully operational and treats mixed low-level, mixed transuranic, and high-level waste, and another that is non-operational.

Internal Inspections -- The operating mixed waste treatment facility is inspected daily and weekly by the operating staff, monthly and weekly by management, and annually by the compliance organization. Any noncompliance for this mixed waste treatment facilities is reported through the unusual occurrence reporting system. No significant compliance problems were identified during FY 1993 at the mixed waste treatment facilities.

External Inspections -- No inspections of the operating mixed waste treatment facility were conducted by the EPA or the State of Washington during FY 1993.

Facility Uparades or Modifications -- No upgrades or modifications to the mixed waste treatment facilities were conducted during FY 1993.

Permit Modifications or Applications -- The Hanford Facility has prepared a RCRA Part A Permit Amendment for one of the treatment facilities currently under construction and submitted on August 31, 1993 a RCRA Part B Permit Application for another treatment facility under construction.

\section{MIXED WASTE DISPOSAL ACTIVITIES FOR FY 1993}

The Hanford Site does not have any mixed waste disposal facilities. However, a RCRA-compliant disposal trench is under construction. 


\section{PUGET SOUND NAVAL SHIPYARD \\ Bromerton, Washington}

Misslon: The Puget Sound Naval Shipyard is a U.S. Department of Navy facility that repairs, overhauls, and maintains Navy ships, Includino nuclear-powered ships. In addition, the Puget Sound Naval Shipyard is the only Naval shipyard that removes defueled reactor compartments from decommissioned nuclear submarines. Drydocks, cranes, waste-handling facilities, and offices are located at the shipyard. Activities supporting nuclear propulsion systems are performed in accordance with the requirements and authority of the Navy Nuclear Propulsion Program, a joint DOE and U.S. Department of Navy program responsible for all activities relating to naval nuclear propulsion.

\section{RCRA COMPLIANCE AGREEMENTS OR ORDERS RELATING TO MIXED WASTE}

The Puget Sound Naval Shipyard currently does not have any RCRA Compliance Agreements or Orders that relate to mixed waste.

\section{MIXED WASTE CHARACTERIZATION ACTIVITIES FOR FY 1993}

There were no activities conducted during FY 1993 to correct any past formal notifications of RCRA violations of waste characterization activities.

\section{MIXED WASTE STORAGE ACTIVITIES FOR FY 1993}

The Puget Sound Naval Shipyard has one mixed waste storage facility that stores mixed low-level waste. This facility has the capacity to store $68.2 \mathrm{~m}^{3}$ of waste and is currently operated under interim status.

Internal Inspections -- The mixed waste storage facility is inspected weekly by the facility operators who document the inspection on the inspection report. Any noncompliances identified during these inspections are reported to the cognizant technical personnel. Separate internal audits are conducted by other technical personnel. No significant compliance problems were identified during FY 1993 at the mixed waste storage facility.

External Inspections -- The Washington State Department of Ecology conducted on March 22, 1993, an unannounced multi-media shipyard inspection which included the mixed waste storage area. No violations were alleged.

Facility Uparades or Modifications -- No upgrades or modifications to the mixed waste storage facility were conducted during FY 1993.

Permit Modifications or Apolications -- No RCRA permit modifications or applications relating to mixed waste were submitted during FY 1993.

\section{MIXED WASTE TREATMENT ACTIVITIES FOR FY 1993}

The Puget Sound Naval Shipyard does not have any mixed waste treatment facilities. 
MIXED WASTE DISPOSAL ACTIVITIES FOR FY 1993

The Puget Sound Naval Shipyard does not have any mixed waste disposal facilities. 

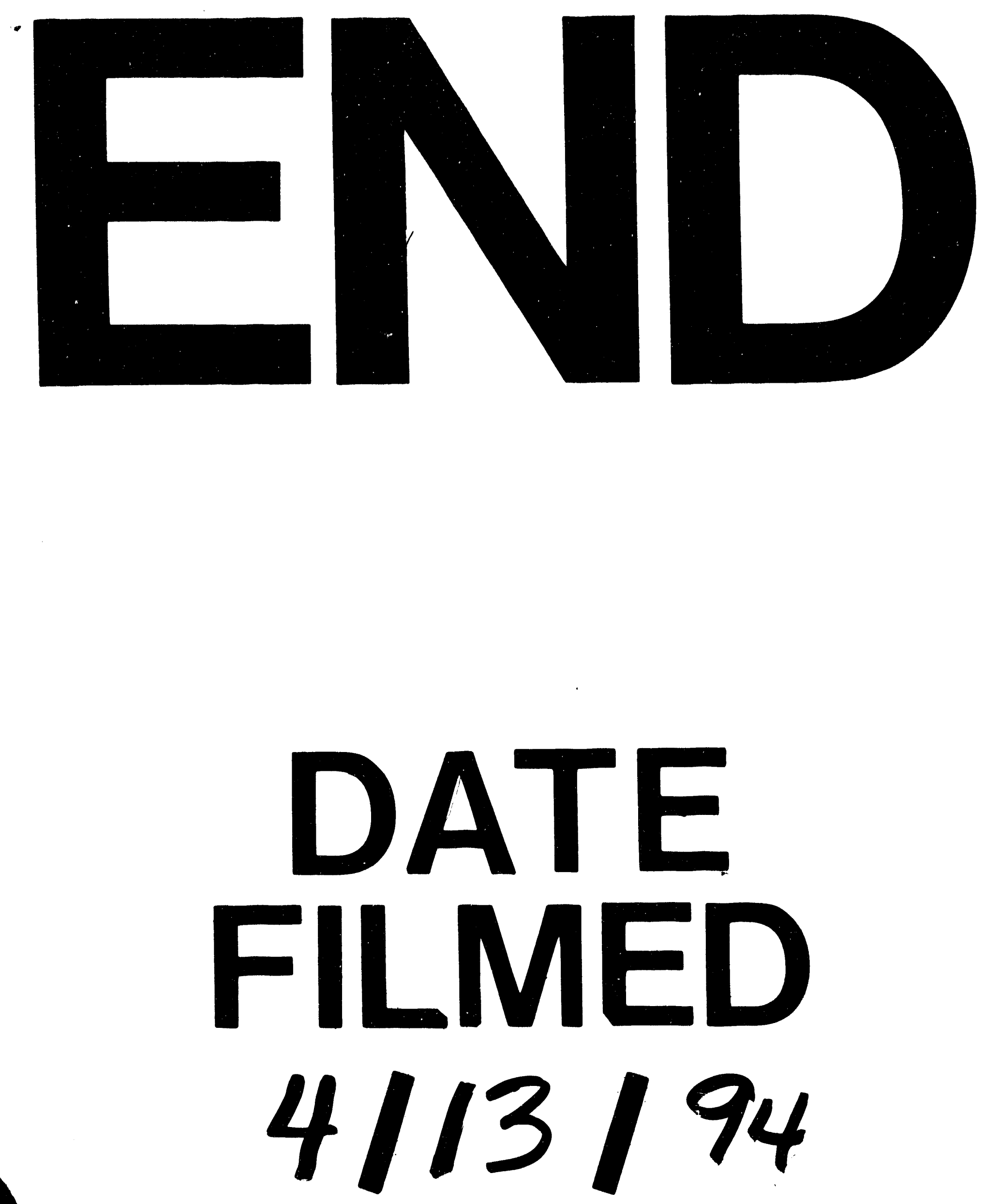

1 